JUL 2 A 1997

$82, \cdot 372$

2. To: (Receiving Organization)

Distribution

5. Proj./Prog./Dept./Oiv.:

HTI

8. Originator Renarks:

Approval/Release

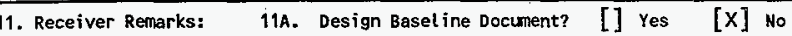

3. From: (Originating organization) Kris Mckinney

6. Design Authority/ Design Agent/Cog. Engr.:
4. Related EDT No.:

7. Purchase Order No.:

9. Equip./Component Ho:

10. Systen/Bldg. /Faciligy:

12. Major Assm. Dwg. Mo.:

13. Permi t/Permis Application No.:

14. Required Response Date:

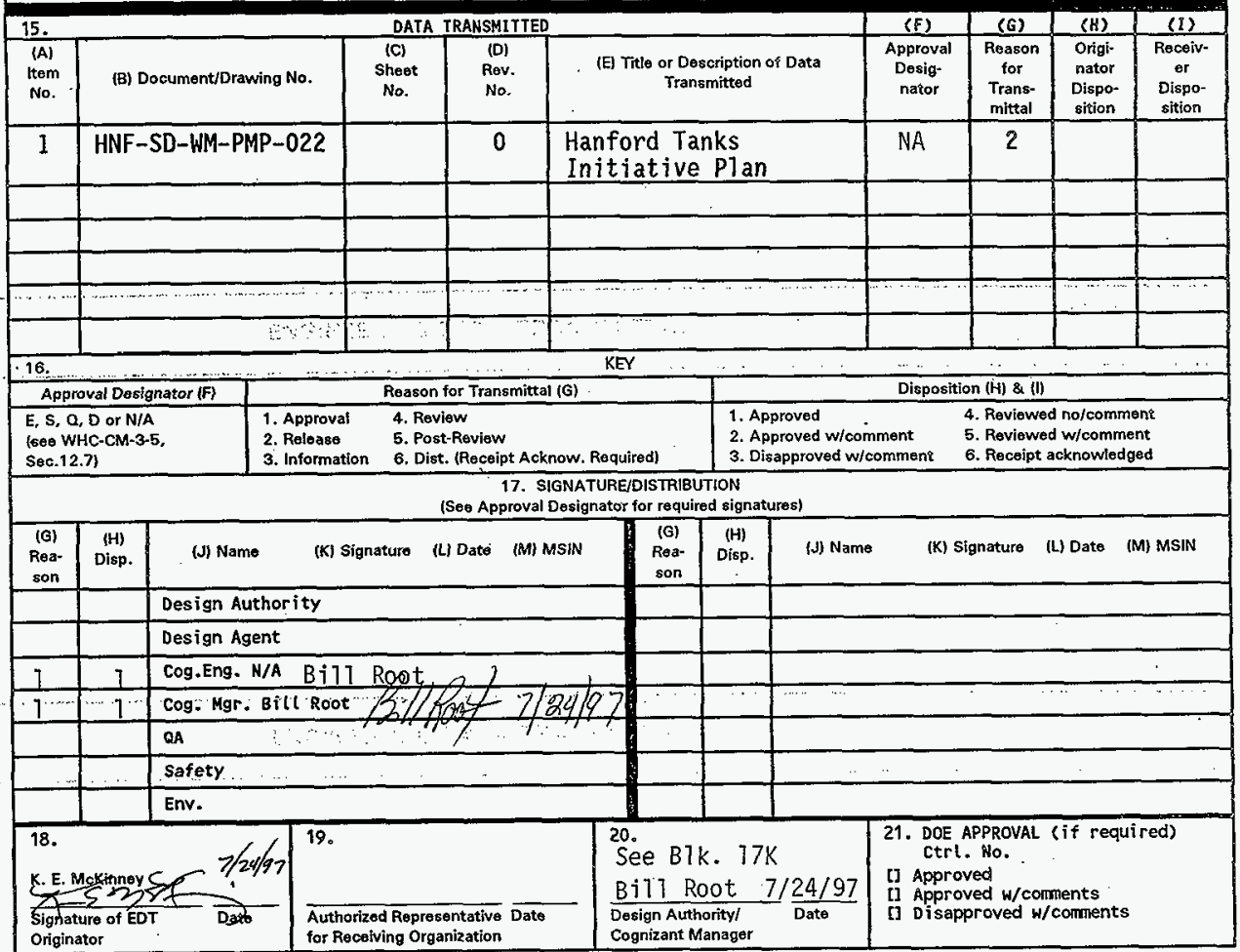

BD-7400-172-2 (05/96) GEF097 


\title{
Hanford Tanks Initiative Plan
}

\author{
K. E. Mckinney
}

Lockheed Martin Hanford Company, Richland, WA 99352

U.S. Department of Energy Contract DE-AC06-96RL13200

EDT/ECN: $\% 43388$ G21702 UC: 900

Org Code: $73600 \quad$ Charge Code: D26Al

B\&R Code: EW3130010 Total Pages: 84 gB 165

Key Words: Tanks, SSTs, DSTs, hard-heel waste, retrieval, HTI

Abstract: The Hanford Tanks Initiative (HTI) is a five-year project resulting from the technical and financial partnership of the U.S. Department of Energy's Office of Waste Management (EM-30) and Office of Science and Technology Development (EM-50). The HTI project accelerates activities to gain key technical, cost performance, and regulatory information on two high-level waste tanks. The HTI will provide a basis for design and regulatory decisions affecting the remainder of the Tank Waste Remediation System's tank waste retrieval Program.

TRADEMARK DISCLAIMER. Reference herein to any specific commercial product, process, or service by trade name, trademark, manufacturer, or otherwise, does not necessarily constitute or imply its endorsement, recommendation, or favoring by the United States Government or any agency thereof or its contractors or subcontractors.

Printed in the United States of America. To obtain copies of this document, contact: Document Control Services, P.0. Box 950, Mailstop H6-08, Richland WA 99352, Phone (509) 372-2420;

Fax (509) 376-4989.
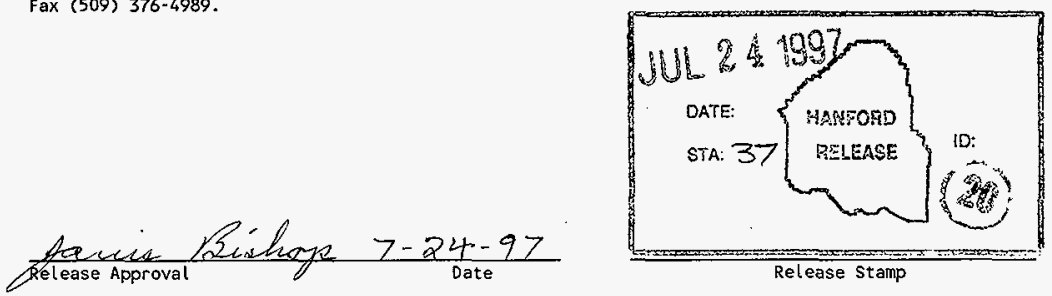

\section{Approved for Public Release}




\section{HANFORD TANKS \\ INITIATIVE \\ PLAN}

July 1997

Prepared for

U.S. Department of Energy

Richland, Washington

by

Lockheed-Martin Hanford Company

Richland, Washington

Informatics, Inc.

Richland, Washington

Numatec Hanford Company

Richland, Washington

Duke Engineering and Services Hanford

Richland, Washington

Battelle Pacific Northwest National Laboratory

Richland, Washington 
The following individuals are greatly appreciated and acknowledged for their contributions in the planning of the Hanford Tanks Initiative:

R. W. Root, Project Manager

Informatics, Inc.

Richland, Washington

K. E. McKinney and P. S. Schaus

Lockheed-Martin Hanford Company

Richland, Washington

E. A. Fredenburg, P. W. Gibbons, and L. B. McDaniel

Numatec Hanford Company

Richland, Washington

J. W. Bloom

Duke Engineering and Services Hanford

Richland, Washington

J. J. Huston

Fluor-Daniel Northwest

Richland, Washington

A. F. Noonan and J. A. Yount

Pacific Northwest Nationai Laboratory

Richland, Washington 


\section{EXECUTIVE SUMMARY}

The Hanford Tanks Initiative (HTI) is a five-year project resulting from the technical and financial partnership of the U.S. Department of Energy's Office of Waste Management (EM-30) and Office of Science and Technology Development (EM-50). The HTI accelerates activities to gain key technical, cost performance, and regulatory information on two highlevel waste tanks. The HTI will provide a basis for design and regulatory decisions affecting the remainder of the Tank Waste Remediation System's tank waste retrieval Program. The HTI Project will:

- Demonstrate an alternative retrieval technology to past-practice sluicing for removal of tank wastes by retrieving the hard-heel waste from single-shell tank 241-C-106 at the Hanford Site.

- Demonstrate through a series of cold tests at vendors' plants alternative retrieval technologies potentially applicable to a broad range of single-shell tanks and waste types.

- Provide a basis for establishing an acceptable approach for defining retrieval performance objectives and end-state conditions for tanks through technology applications, performance assessments, and risk analyses.

- Conduct residual waste characterization to the extent needed to support the basis for waste retrieval and tank closure.

- Obtain the acceptance of regulatory agencies and stakeholders for methods and processes to define completion of tank waste retrieval.

- Establish new or improved methods to achieve safe and efficient environmental remediation at the Hanford Site.

- Develop reliable cost information for various levels of retrieval to support program and regulatory decisions.

The HTI Project activities began in fiscal year 1997 and focuses on two tanks (241-AX-104 for developing closure basis criteria and 241-C-106 for demonstrating alternative retrieval technology for hard heel removal). The project will be staffed with participants from the U.S. Department of Energy, the Project Hanford Management Contractors, Pacific Northwest National Laboratory, the EM-50 Tanks Focus Area, other national laboratories, and private industry. 
Technologies and services will be acquired through performance-based contracts with private industry. Performance-based specifications will be used to develop technologies and acquire services from the national laboratories. A major goal is to establish teaming relationships with the private sector and national laboratories to meet the performance requirements for retrieval and characterization technologies in a cost-effective manner. 


\section{CONTENTS}

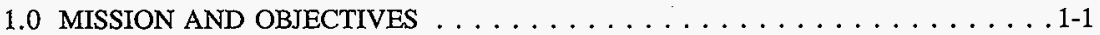

1.1 SCOPE . . . . . . . . . . . . . . . . . . . . . .

1.1.1 Tank 241-C-106 Retrieval Demonstration . . . . . . . . . . . . . 1-2

1.1.2 Tank 241-AX-104 Closure Assessment Demonstration . . . . . . . . . 1-3

1.2 BACKGROUND . . . . . . . . . . . . . . . . . .

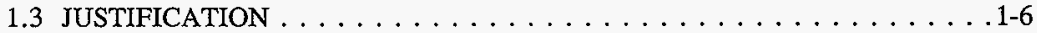

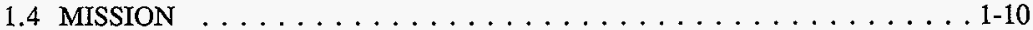

1.5 HANFORD TANKS INITIATIVE OBJECTIVES $\ldots \ldots \ldots \ldots \ldots \ldots$

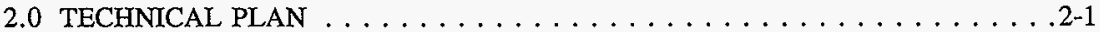

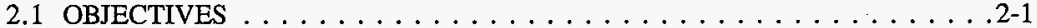

2.2 RESIDUAL WASTE REMOVAL . . . . . . . . . . . . . . 2-2

2.2.1 Description of Technical Approach $\ldots \ldots \ldots \ldots \ldots \ldots . \ldots .2-2$

2.2 .2 Status of Technology . . . . . . . . . . . . . . . 2-3

2.3 ESTABLISHING RETRIEVAL PERFORMANCE CRITERIA . . . . . . . . . 2-3

2.3.1 Description of Technical Approach . . . . . . . . . . . . 2-4

2.3.2 Status of Technology . . . . . . . . . . . . . . . 2-4

2.4 CONTAMINANT TRANSPORT MODELING $\ldots \ldots \ldots \ldots \ldots \ldots \ldots . . \ldots \ldots$

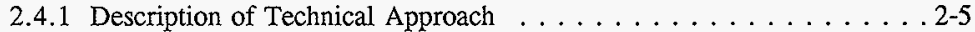

2.4 .2 Status of Technology . . . . . . . . . . . . . . 2-6

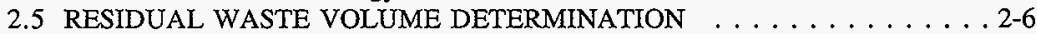

2.5.1 Description of Technical Approach . . . . . . . . . . . . 2-7

2.5.2 Status of Technology . . . . . . . . . . . . . . . . 2-8

2.6 RESIDUAL TANK WASTE SAMPLING . . . . . . . . . . . . 2-8

2.6.1 Description of Technical Approach . . . . . . . . . . . 2-9

2.6 .2 Status of Technology . . . . . . . . . . . . . . 2-10

2.7 SOIL SAMPLING AND CHARACTERIZATION $\ldots \ldots \ldots \ldots \ldots$. . . . . . . .

2.7.1 Description of Technical Approach . . . . . . . . . . . 2-11

2.7.2 Status of Technology . . . . . . . . . . . . . 2-11

3.0 HANFORD TANKS INITIATIVE MANAGEMENT APPROACH . . . . . . . . . 3-1

3.1 HANFORD TANKS INITIATIVE PROGRAM ORGANIZATION $\ldots \ldots .3$. $\ldots$

3.2 HANFORD TANKS INITIATIVE PROJECT MANAGER $\ldots \ldots \ldots \ldots$. . . . . .

3.3 TANK 241-C-106 RETRIEVAL DEMONSTRATION . . . . . . . . . . . 3-4

3.4 TECHNOLOGY INTEGRATION AND ENGINEERING $\ldots \ldots \ldots \ldots . . .3-4$

3.5 ENVIRONMENT, SAFETY, AND HEALTH $\ldots \ldots \ldots \ldots \ldots \ldots . . \ldots \ldots$

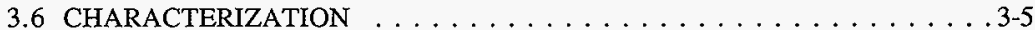

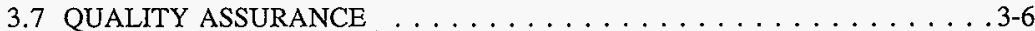

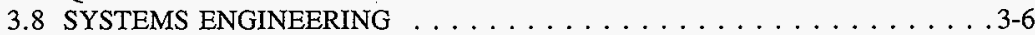

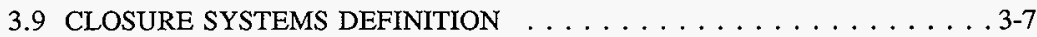

3.10 ADMINISTRATIVE SUPPORT . . . . . . . . . . . . . . . .7 


\section{CONTENTS (continued)}

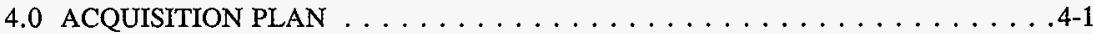

4.1 TANK 241-AX-104 CLOSURE ASSESSMENT . . . . . . . . . . 4-2

4.2 ALTERNATE RETRIEVAL TECHNOLOGY . . . . . . . . . . . 4-2

4.3 TANK 241-C-106 RETRIEVAL DEMONSTRATION . . . . . . . . . . 4-2

5.0 CLOSURE STRATEGY . . . . . . . . . . . . . . . . . . .5-1

5.1 FRAMEWORK FOR STRATEGY $\ldots \ldots \ldots \ldots \ldots \ldots \ldots$. . . . . . . .

5.2 CLOSURE ALTERNATIVES . . . . . . . . . . . . . . . 5-2

5.3 STRATEGY FOR CLOSURE OF ALL SINGLE-SHELL TANK FARMS . . . 5-3

5.4 STRATEGY FOR DEVELOPING RETRIEVAL PERFORMANCE

CRITERIA . . . . . . . . . . . . . . . . . .5-4

6.0 INVOLVEMENT OF REGULATORY AGENCIES $\ldots \ldots \ldots \ldots \ldots \ldots$. $\ldots \ldots$

6.1 OBJECTIVE .......................... . . . . .

6.2 PROCESS AND FRAMEWORK $\ldots \ldots \ldots \ldots \ldots \ldots \ldots \ldots \ldots \ldots$

7.0 STAKEHOLDER INVOLVEMENT $\ldots \ldots \ldots \ldots \ldots \ldots \ldots \ldots \ldots \ldots \ldots$. $\ldots \ldots \ldots$

8.0 SYSTEMS ENGINEERING PROCESS $\ldots \ldots \ldots \ldots \ldots \ldots \ldots \ldots$. $\ldots \ldots \ldots$

9.0 REFERENCES . . . . . . . . . . . . . . . . . . . . .9-1

\section{APPENDICES:}

A HANFORD TANKS INITIATIVE WORK BREAKDOWN STRUCTURE $\ldots . .$. A-1

B HANFORD TANKS INITIATIVE DETAILED SCHEDULES $\ldots \ldots \ldots \ldots$ B-1

C RELEVANT ACTIVITIES AT HANFORD AND OTHER SITES OF THE U.S. DEPARTMENT OF ENERGY NUCLEAR WEAPONS COMPLEX . . . . . C-1

D PROGRAMMATIC RISK ASSESSMENT $\ldots \ldots \ldots \ldots \ldots \ldots$ D-1

E SAFETY PROGRAM IMPLEMENTATION $\ldots \ldots \ldots \ldots \ldots \ldots$ E-1

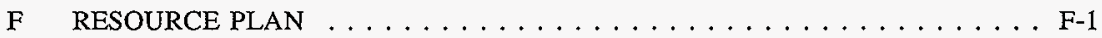

$\mathrm{G}$ BUSINESS AND FINANCIAL PLAN $\ldots \ldots \ldots \ldots \ldots \ldots \ldots$ G-1

H SCHEDULE CONTROL, COST CONTROL, AND REPORTING $\ldots \ldots \ldots$ H-1

I CHANGE CONTROL AND BASELINE MANAGEMENT $\ldots \ldots \ldots \ldots \ldots$ J-1

J PERFORMANCE MANAGEMENT AND EARNED VALUE $\ldots \ldots \ldots \ldots \ldots$ K-1 
HNF-SD-WM-PMP-022, Rev. 0

\section{LIST OF FIGURES}

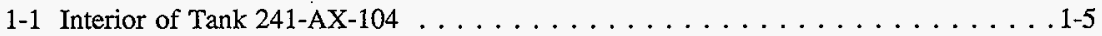

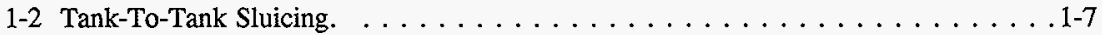

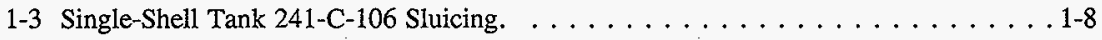

3-1 Hanford Tanks Initiative Organizational Structure . . . . . . . . . . . . . 3-2

\section{LIST OF TABLES}

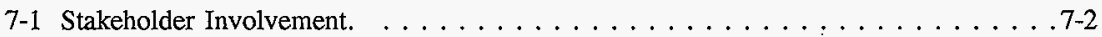


HNF-SD-WM-PMP-022, Rev. 0

This page intentionally left blank. 


\section{LIST OF TERMS}

ACTR

ACV

ACWP

ADS

AM

ALARA

BA

BAC

BCWP

BCWS

CAA

CAM

CAP

CERCLA

CPI

DOE

EA

EAC

EC

Ecology

EIS

EM

EPA

ERT

ES\&H

ETC

FDS

FONSI

GAAT

$\mathrm{HAB}$

HLW

HTI

INEEL

IRM

ISSTRS

LDR
Acquire Commercial Technology for Retrieval

at completion variance

actual cost of work performed

activity data sheets

account manager

as low as reasonably achievable

budget analyst

budget at completion

budgeted cost of work performed

budgeted cost of work scheduled

cost account authorization

cost account manager

cost account plan

Comprehensive Environmental Response, Compensation, and Liability Act of 1980

continuous plot index

U.S. Department of Energy

environmental assessment

estimate at completion

engineering and construction

Washington State Department of Ecology

Environmental Impact Statement

environmental management

U.S. Environmental Protection Agency

electrical resistance tomography

Environmental Safety, and Health

estimate to complete

financial data system

Finding of No Significant Impact

Gunite and Associated Tanks

Hanford Advisory Board

high-level waste

Hanford Tanks Initiative

Idaho National Engineering and Environmental Laboratory

information resource management

initial single-shell tank retrieval system

Land Disposal Restriction. 


\section{LIST OF TERMS}

$\begin{array}{ll}\text { LDUA } & \text { light-duty utility arm } \\ \text { LDMM } & \text { leak detection, monitoring, and mitigation } \\ \text { LLLW } & \text { liquid low-level waste } \\ \text { LLW } & \text { low-level waste } \\ \text { MCS } & \text { Management Control System } \\ \text { MEPAS } & \text { Multimedia Environmental Pollutant Assessment System (computer } \\ & \text { model) } \\ \text { MOU } & \text { memorandum of understanding } \\ \text { MYPP } & \text { Multi-Year Program Plan } \\ \text { NEPA } & \text { National Environmental Policy Act of 1969 } \\ \text { NESHAP } & \text { National Emission Standards for Hazardous Air Pollutants } \\ \text { NRC } & \text { U.S. Nuclear Regulatory Commission } \\ \text { ORNL } & \text { Oak Ridge National Laboratory } \\ \text { PA } & \text { performance assessment } \\ \text { PC } & \text { program/project control } \\ \text { PM } & \text { program manager } \\ \text { PHMC } & \text { Project Hanford Management Contractor } \\ \text { PORFLOW } & \text { porous media flow (a computer model) } \\ \text { PTS } & \text { project tracking system } \\ \text { PUREX } & \text { plutonium-uranium extraction (a chemical process/Hanford facility) } \\ \text { QA } & \text { quality assurance } \\ \text { RETC } & \text { Retention/Conductivity } \\ \text { RFP } & \text { request for proposal } \\ \text { SEMP } & \text { Systems Engineering Management Plan } \\ \text { SEPA } & \text { State (of Washington) Environmental Policy Act } \\ \text { SMS } & \text { site management system } \\ \text { SPI } & \text { schedule performance index } \\ \text { SRS } & \text { Savannah River Site } \\ \text { SST } & \text { single-shell tank } \\ \text { STCG } & \text { Site Technology Coordinating Group } \\ \text { TAP } & \text { Toxic Air Pollutants } \\ \text { TFA } & \text { Tanks Focus Area } \\ \text { TIE } & \text { Technology Integration and Engineering } \\ \text { TMS } & \text { Topographical Mapping System } \\ \text { TRC } & \text { Tank Waste Retrieval and Closure } \\ \text { Tri-Party } & \text { Hanford Federal Facility Agreement and Consent Order } \\ \text { Agreement } & \\ & \end{array}$


HNF-SD-WM-PMP-022, Rev. 0

\section{LIST OF TERMS}

TWRS

VAR

WAC

WBS
Tank Waste Remediation System variance analysis report

Washington Administrative Code

work breakdown structure 
HNF-SD-WM-PMP-022, Rev. 0

This page intentionally left blank. 


\subsection{MUSSION AND OBJECTIVES}

To support the Tank Waste Remediation System (TWRS) mission (Knutson 1995), waste must be retrieved from tanks and immobilized, and the nearly empty storage facilities in the tank farm operable units must be closed in a manner that is safe, environmentally sound, and cost-effective. The Hanford Federal Facility Agreement and Consent Order (Ecology et al. 1994) (referred to as the Tri-Party Agreement) established milestones for completing specified activities to carry out this mission. Among these is Milestone M-45-00, which requires retrieval of as much waste as technically possible, with tank waste residues not to exceed $10.2 \mathrm{~m}^{3}\left(360 \mathrm{ft}^{3}\right)$ in each 100-Series tank, $0.85 \mathrm{~m}^{3}\left(30 \mathrm{ft}^{3}\right)$ in each 200-Series tank, or the limit of waste retrieval technology capability, whichever is less. This milestone also requires closure of all single-shell tanks (SST) by 2024 .

Capability to retrieve some types of waste by hydraulic sluicing is uncertain. Previously, a sluicing process was used that was not entirely effective on hard-packed solids (referred to as a "hard heel"). In addition, the effects of sluicing on leakage of wastes to the soil must be understood. Also unknown is whether tank farms may be closed with residual wastes in the tank and surrounding soils in compliance with applicable environmental regulations, even if the percentage of waste retrieved complies with Milestone M-45-00.

There is significant program risk unless retrieval performance requirements are defined and initial retrieval systems are developed and deployed in Hanford tanks before contractor bids are solicited for the retrieval scope of the TWRS privatization program (termed "Phase II privatization"). The preparation of the request for proposal (RFP) for Phase II privatization is tentatively planned to begin in the year 2002. The mission of the Hanford Tanks Initiative (HTI) is to minimize these programmatic uncertainties and associated risks by employing appropriate technologies and methods to achieve the following:

- Determine state-of-the-art capability to retrieve difficult-to-remove hard-heel waste from a SST.

- Establish retrieval performance criteria, including cost.

- Characterize waste to measure compliance with retrieval performance criteria.

- Provide a basis for future National Environmental Policy Act of 1969 (NEPA), safety, and regulatory actions affecting waste retrieval and operable unit closure for tank farms.

The HTI is to be completed in five years. The HTI will provide the U.S. Department of Energy (DOE) with information vital for the requirements and specifications of the retrieval scope of the TWRS privatization program. 


\subsection{SCOPE}

The scope of the HTI includes the following:

- Retrieve the hard-heel waste (a dense layer of waste solids at the bottom of a tank) and any residual soft sludges remaining in tank 241-C-106 and assess the capability of the retrieval technology to meet the desired performance objectives.

- Test alternate waste retrieval technologies using tank waste simulants, including waste retrieval capabilities applicable to a leaking SST.

- Characterize residual waste to assess compliance with waste retrieval performance criteria in tank 241-AX-104 (previously sluiced to remove waste) to assess longterm risk.

- Develop waste retrieval performance criteria, through assessment of risk to human health and the environment, to determine readiness to close SSTs.

The scope of this plan includes identification and description of the following aspects of the HTI:

- Mission

- Objectives

- Technical approach

- Management approach

- Acquisition strategy

- Tank closure strategy

- Regulatory and stakeholder involvement

- Systems engineering process.

Details of the work breakdown structure (WBS), schedules, related activities at other sites, programmatic risk assessment, and aspects of project management and implementation are provided in Appendices A through J.

\subsubsection{Tank 241-C-106 Retrieval Demonstration}

In preparation for demonstrating the retrieval of hard-heel wastes from tank 241-C-106 several preliminary activities will need to be completed; (1) evaluation of alternative technologies, (2) acquisition of vendor services for waste retrieval, (3) modifications to the waste retrieval tank, the receiver $\operatorname{tank}(\mathrm{s})$, and an existing temporary waste transfer line (as required), and (4) procurement, installation, and qualification of all associated support equipment. 
Activities supporting the retrieval of hard-heel waste from tank 241-C-106 include controlling and monitoring waste retrieval operations and storage and containment of the tank contents during waste retrieval activities. These activities will start with the preparation of the tank for waste retrieval and will be completed when the waste has been retrieved and the retrieval been removed from the tank and disassembled.

A separate project (Project W-320) will install the equipment needed to sluice the highheat soft-sludge waste from tank 241-C-106. It is anticipated that most of the soft sludges will be retrieved before in-tank work by the HTI is initiated. After completing sluicing operations, an evaluation will be made of the amount of waste remaining in the tank and its physical and chemical characteristics. Equipment remaining in the tank after sluicing operations will be used to the maximum extent possible for hard-heel waste removal.

The scope of the HTI hard-heel waste retrieval activities includes the following:

- Procure and evaluate two alternative waste retrieval systems, based on system definition and evaluations of test results from critical testing.

- Based on the system definition results, procure integrated tank retrieval services using the selected technology to support retrieval of hard-heel waste and any residual soft sludges from tank 241-C-106.

- Upgrade and modify tank structures and utilities, as required by retrieval operations.

\subsubsection{Tank 241-AX-104 Closure Assessment Demonstration}

The scope of this project is to establish retrieval performance criteria for closure, characterize residual waste, assess compliance with retrieval performance criteria, and determine readiness for closure. Tank 241-AX-104 will be evaluated for closure suitability because the tank was previously sluiced as part of strontium-recovery operations in the early 1970's. Residual tank waste and waste leaked to the vadose zone will be characterized, as necessary, to determine whether the tank is ready for closure.

Characterization will be performed by equipment such as light-duty utility arm (LDUA) for performing in-tank photography; an in-tank crawler system (ITS) to measure residual waste thickness, distribution and volume, and to obtain waste samples for laboratory analyses; a topographical mapping system (TMS) for measuring variations in the residual waste and tank surfaces; and a cone penetrometer for assessing contamination in the vadose zone near the tank. The nature of the vadose zone, including site-specific sediment thicknesses and hydraulic properties and the distribution and relative concentration of contaminants in the sediments underlying tank $241-\mathrm{AX}-104$, will be determined to assist in predicting the long-term environmental impact of a closed tank. 
A key activity is to establish suitable performance criteria for waste retrieval that will accommodate all applicable regulations and be potentially applicable not only to closure of tank 241-AX-104 but to closure of all SSTs at the Hanford Site. Identifying retrieval performance criteria will involve regulatory agency and stakeholder participation. This consensus-forming process will focus on establishing criteria that are expected to necessitate modeling the migration of residual contaminants in groundwater to evaluate long-term performance of the closed tank, as well as assessment of risk to remediation workers and the public resulting from closure operations.

An engineering study of end-state alternatives for the AX tank farm includes options for remediation of contaminated soil and tank farm ancillary equipment, as well as options for removal of tanks and for placement of surface barriers. End-state alternatives for the AX tank farm will be compared on the basis of cost, technical feasibility, short-term risk, and long-term performance. This will provide the basis for determining whether tank AX-104 is ready to close, whether additional waste must be retrieved to close the tank, or whether more data are needed to make that decision.

\subsection{BACKGROUND}

Tank 241-AX-104 is a 3,800 $\mathrm{m}^{3}$ (1 Mgai) SST located in the AX tank farm in the 200 East Area of the Hanford Site. The tank was operated between 1965 and 1976 to store radioactive waste and support strontium recovery operations. The tank received selfconcentrating (i.e., boiling) waste from the Plutonium-Uranium Extraction (PUREX) Plant and B Plant between the third quarter of 1965 and the fourth quarter of 1972. The tank was classified as an assumed leaker in November 1977. The tank was sluiced between the second and third quarters of 1977, and from the beginning of 1978 through mid-April of 1978. It was sluiced to recover ${ }^{90} \mathrm{Sr}$ from the sludge and ${ }^{137} \mathrm{Cs}$ from the supernate, and to remove the tank from service.

The tank is lined with carbon steel, with a reinforced-concrete shell, dome, and base $\sim 0.6-\mathrm{m}$ (2-ft) thick. The tank is $14-\mathrm{m}(45.5-\mathrm{ft})$ high, $23-\mathrm{m}(75-\mathrm{ft})$ in dia., and has a flat bottom. Currently, the tank is reported to contain approximately $25 \mathrm{~m}^{3}(7,000 \mathrm{gal})$ of sludge. An in-tank photograph (Figure 1-1) shows what appears to be bare metal with small amounts of sludge covering parts of the bottom of the tank. If what appears in the photograph is in fact bare metal, tank 241-AX-104 may represent a 100-Series SST from which waste has been retrieved to the "limit of waste retrieval technology capability" for past-practice sluicing. A better estimate of waste volume will be obtained during planned waste characterization activities for 241-AX-104, during FY 1998. 
Figure 1-1. Interior of Tank 241-AX-104,

Showing Current Condition after Previous Sluicing.

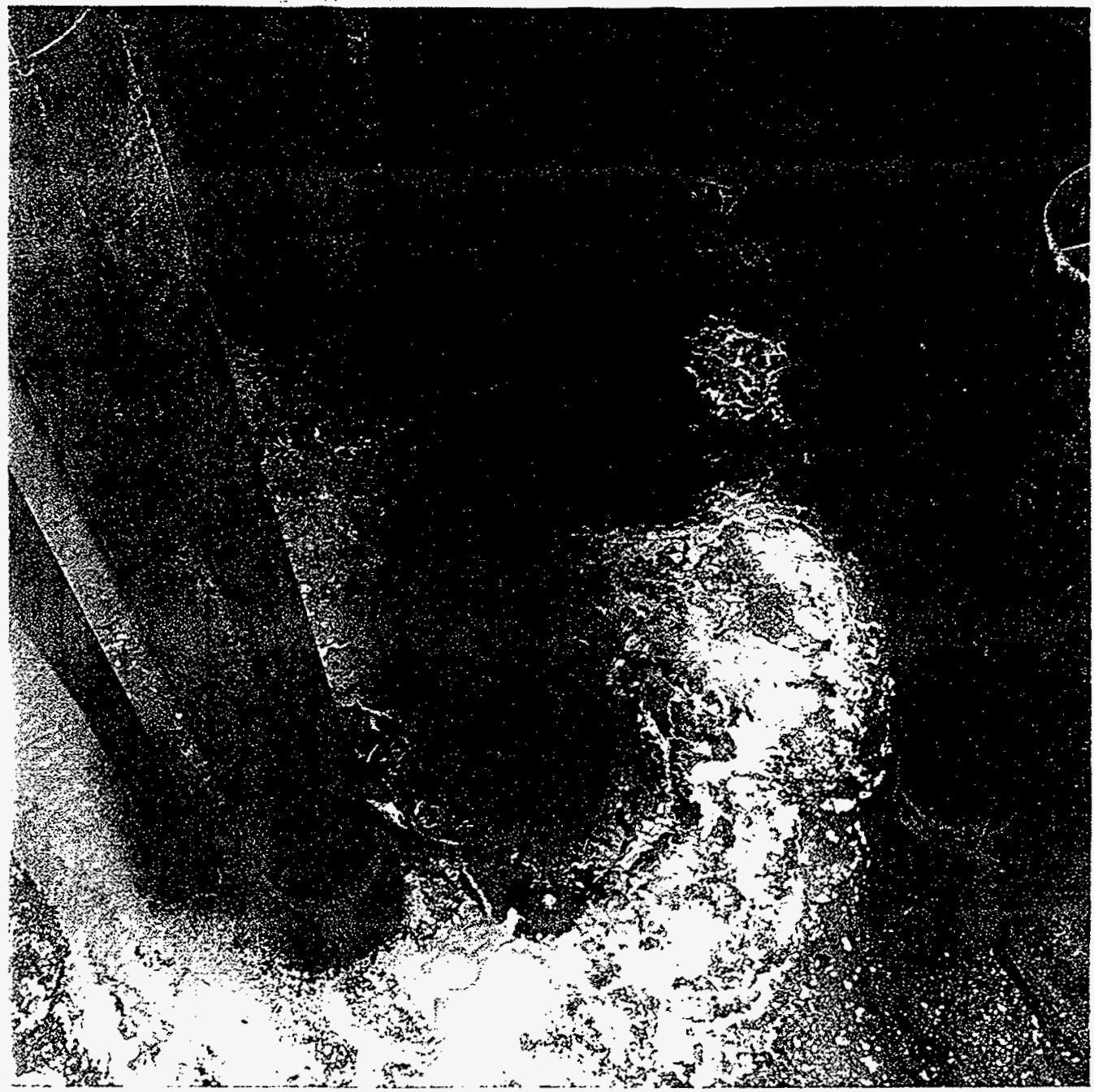


Tank $241-\mathrm{C}-106$ is a $2,000-\mathrm{m}^{3}$ (530,000-gal) capacity SST located in the $\mathrm{C}$ tank farm in the 200 East Area of the Hanford Site. The tank has been used to store radioactive waste since 1947. Between mid-1963 and mid-1969, tank 241-C-106 received high-heat waste, including neutralized PUREX high-level waste (HLW) and strontium-bearing solids from the strontium and cesium recovery program. In 1971 temperatures in excess of $99^{\circ} \mathrm{C}\left(210^{\circ} \mathrm{F}\right)$ were observed in the tank. To prevent the sludge from drying out and the tank from overheating, $\sim 23 \mathrm{~m}^{3}$ (6,000 gal) of cooling water is added to the tank each month.

Tank 241-C-106 was withdrawn from active service in 1979 and is categorized as sound (i.e., not confirmed or suspected to be leaking). The heat generation rate of the waste in the tank is currently $110,000 \mathrm{Btu} / \mathrm{h}$. The waste level in the tank is $\sim 193 \mathrm{~cm}$ (76 in.) above the tank floor.

The high-heat waste of tank $241-\mathrm{C}-106$ has been identified as a priority-one safety issue and the planned resolution is to remove enough waste to reduce the tank heat load to $<40,000 \mathrm{Btu} / \mathrm{h}$. It is estimated that this can be achieved by removing $640 \mathrm{~m}^{3}(170,000 \mathrm{gal})$ of soft sludge. The equipment installed by Project W-320 will be used to remove this sludge by utilizing past-practice hydraulic sluicing (Figures 1-2 and 1-3). However, this sluicing is not expected to dislodge and remove the 46 to $61 \mathrm{~cm}$ (18 to 24 in.) of hard-heel sludge in the bottom of the tank. Furthermore, past-practice sluicing may not be an acceptable method for removing waste from leaking tanks because of potential harm to the environment caused by washing waste into the soil through previous leak sites.

\subsection{JUSTIFICATION}

Tri-Party Agreement milestones associated with the final retrieval of waste from tank 241-C-106 include Milestone M-45-03-T02 "Initiate Final Retrieval Demonstration of 241-C-106" due June 2002, and Milestone M-45-03-T01 "Complete SST Waste Retrieval Demonstration" due September 2003.

Additional justification derives from the DOE initiative to privatize the treatment and immobilization of HLW and low-level waste (LLW). The provider(s) of these services will be paid when an acceptable product is produced. Phase I of privatization is intended to provide the private sector with sufficient confidence to bid on subsequent, large-scale pretreatment and immobilization work, and the ability to obtain the necessary financing. The current plan is to include tank retrieval operations as part of the TWRS Phase II privatization scope. However, unlike HLW immobilization and LLW pretreatment and immobilization, waste retrieval from SSTs is not part of Phase I privatization. 

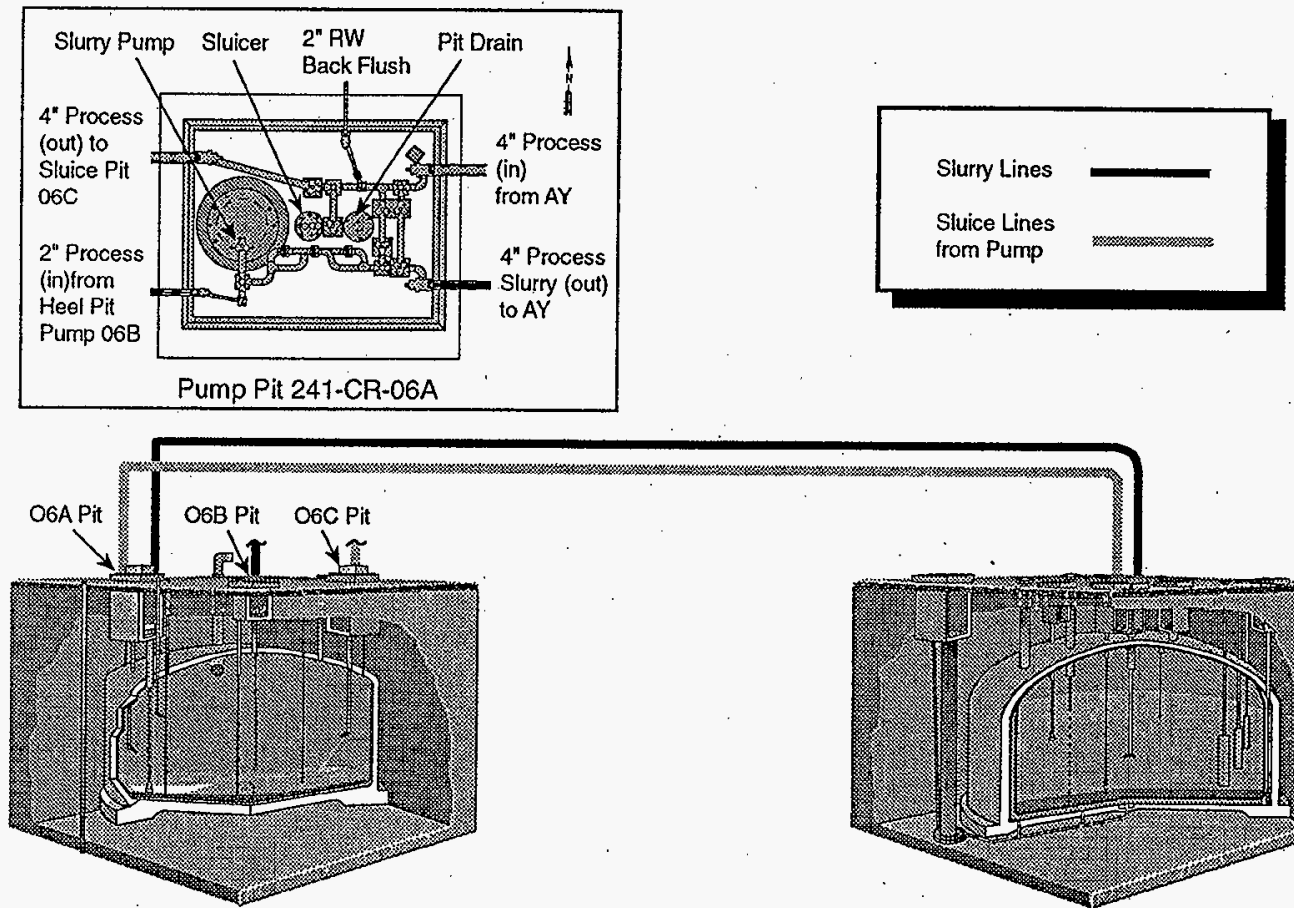

Tk 241-C-106

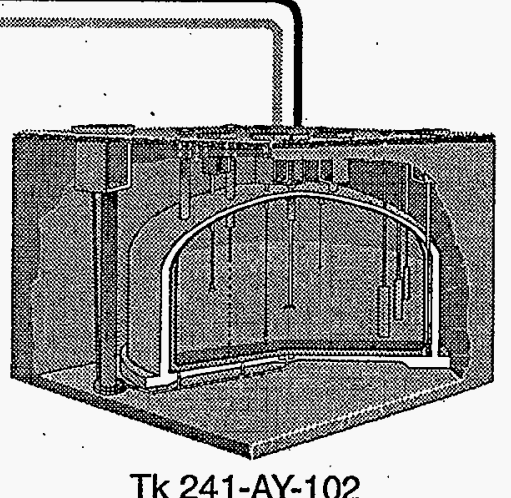

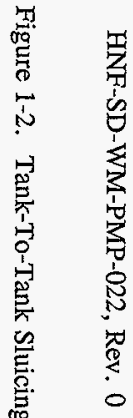

29310055.7 
HNF-SD-WM-PMP-022, Rev. 0

Figure 1-3. Single-Shell Tank 241-C-106 Sluicing.

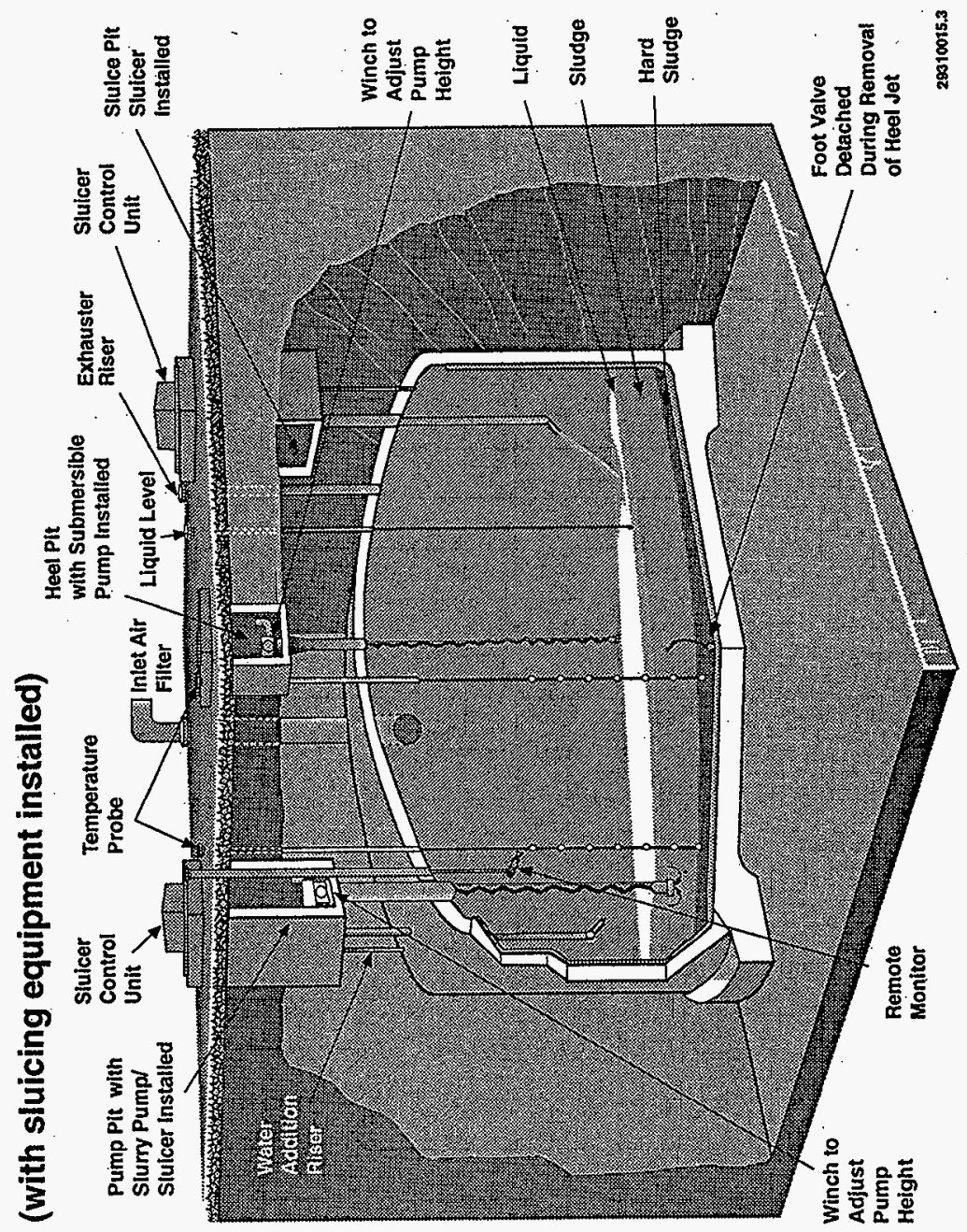


SST waste retrieval is one of the most technically challenging elements of the TWRS program. Consequently, an initiative analogous to the Phase I demonstration for pretreatment and immobilization is needed to provide confidence for this portion of the TWRS program as well. The waste retrieval requirement currently specified in the Tri-Party Agreement is an interim goal that is intended to be refined based on actual retrieval system performance and subsequent evaluation of cost, technical practicability, and risks. As such, retrieval system performance criteria that would apply to the Phase II privatization contractor cannot currently be specified.

Development and demonstration of the technology for SST waste retrieval, waste characterization, and tank closure have been identified by the Tanks Subgroup of the Site Technology Coordinating Group (STCG) as the highest priority technology need at the Hanford Site. The STCG consists of a cross section of Hanford Site stakeholders and is chartered to help determine priorities of technology development and acquisition for the Hanford Site.

As many as 131 SSTs may require hard-heel waste removal. The volume of these difficult-to-retrieve wastes is estimated at $21,000 \mathrm{~m}^{3}(5.6 \mathrm{Mgal})$, and is not expected to be amenable to removal by past-practice sluicing. Therefore, the limits of technology for hardheel waste retrieval need to be established to the extent that is "technically and economically practical." Removal of the hard-heel waste remaining in tank 241-C-106 specifically constitutes progress toward accomplishing two Tri-Party Agreement milestones:

- Retrieve as a minimum, an average of 99 vol. percent of the waste from all tanks (leaving $360 \mathrm{ft}^{3}$ maximum per tank), or determine the economic and technical limits of retrieval technology;

- Empty one of the 177 Hanford Site tanks.

Determining whether residual waste may remain in SSTs when they are considered ready for closure, and if so how much, is crucial to specifying retrieval system performance requirements. Criteria development for tank closures at the Savannah River Site (SRS) and the Oak Ridge National Laboratory (ORNL) will generally support similar activities at other DOE facilities, including the Hanford Site. However, significant differences between arid sites (such as Hanford) and wet sites (like the SRS and ORNL) exist that will affect waste retrieval, preparations for tank closure, and modeling approaches used to assess closure system performance. 


\subsection{MISSION}

The HTI will perform activities in a safe, efficient, and environmentally-acceptable manner that complies with As Low As Reasonably Achievable (ALARA) criteria. By 2001 the HTI will apply technologies and processes in tanks 241-C-106 and 241-AX-104 to:

- Retrieve difficult-to-remove SST hard-heel wastes.

- Establish retrieval performance criteria for final disposition of tanks.

- Characterize waste to measure compliance with retrieval performance criteria.

- Provide a basis for future NEPA, safety, and regulatory actions affecting waste retrieval and operable unit closure for tank farms.

\subsection{HANFORD TANKS INITIATIVE OBJECTIVES}

The HTI objectives are to:

- Retrieve the hard-heel waste from tank 241-C-106 to the extent that it is "technically and economically practical".

- Characterize and remove waste in a SST, using methods that mitigate potential for leakage and could be applied to leaking tanks.

- Document performance, cost, and the occupational risk incurred relative to the long-term risk reduction to the public and the environment in order to provide data for determining how much waste must be retrieved for closure of a SST.

- Establish retrieval performance criteria needed to refine the interim retrieval goal specified in Tri-Party Agreement Milestone M-45-00 criteria of residual waste for 100-Series tanks.

- Establish a basis for classifying residual waste as "incidental" (non-HLW) through interactions with the U.S. Nuclear Regulatory Commission (NRC).

- Reduce programmatic risk associated with Phase II privatization, ensure extensive participation of industry, and provide technical baseline information on SST retrieval and readiness for tank closure.

- Work with regulatory agencies and stakeholders to establish acceptable decision methods and data for articulating SST closure criteria based on performance, cost, risk, and safety tradeoffs.

- Ensure extensive participation of the private sector in HTI demonstrations. 
HNF-SD-WM-PMP-022, Rev. 0

- Develop technology acquisition strategies to optimize the use of outside resources and skills.

- Provide input to the TWRS retrieval function regarding tank cleanout requirements and waste retrieval architecture. 
HNF-SD-WM-PMP-022, Rev. 0

This page intentionally left blank. 


\subsection{TECHNICAL PLAN}

This technical plan describes the approach that will be used to establish waste retrieval objectives for the AX tank farm, assess tank 241-AX-104 readiness for closure, and to remove the hard-heel waste remaining in tank 241-C-106 after it has been sluiced by the equipment installed by Project W-320. The purpose of this technical plan is to provide a means to obtain agreement with stakeholders on the technical objectives and approach for this project. The technical plan is divided into the following sections: Section 2.1 briefly summarizes the technical objectives of this project; Sections 2.2 through 2.7 describe the proposed technical approach, status of leading-candidate technology, and alternatives.

\subsection{OBJECTIVES}

The technical objectives of this project are as follows:

1. Residual Waste Removal. Apply technologies and processes to remove the hard-heel and other waste that is expected to remain in tank 241-C-106 following waste retrieval by sluicing. The objective is to remove sufficient waste that the residue will be $\leq 10.2 \mathrm{~m}^{3}\left(360 \mathrm{ft}^{3}\right)$ or the limit of waste retrieval technology (Tri-Party Agreement Milestone M-45-00), and to establish what is technically and cost-effectively feasible for tank 241-C-106.

2. Establishing Retrieval Performance Criteria. For the AX tank farm translate stakeholder values into quantitative measures of the performance of alternative waste retrieval technologies that can be used to compare retrieval and closure alternatives, and to establish performance criteria for closure. Achieving this objective will require performance analyses and risk and compliance assessments to assess end-state options for the AX tank farm and closure readiness for tank 241-AX-104.

3. Contaminant Transport Modeling. Using input from stakeholders and regulatory agencies, develop the method and process to predict the transport of residual radioactive and hazardous materials from the tank, surrounding contaminated soil, and ancillary equipment to the environment. Apply this analytical method to tank $241-\mathrm{AX}-104$ to determine the risk to the environment resulting from various tank closure options.

4. Residual Waste Volume Determination. Select instruments to measure the total residual waste volume remaining in tanks $241-\mathrm{AX}-104$ and $241-\mathrm{C}-106$ after sluicing operations. This measurement capability is required to determine whether sufficient waste has been retrieved to allow operable unit closure in accordance with the provisions of Milestone M-45-00. 
5. Residual Tank Waste Sampling. Select instruments to sample the relatively small quantities of waste remaining in tank 241-AX-104 to support tank closure.

6. Soil Sampling and Characterization. Select instruments to measure contamination in the soil surrounding tank 241-AX-104 and obtain other hydrologic characterization information required to accomplish tank closure.

\subsection{RESIDUAL WASTE REMOVAL}

Tank 241-C-106, classified as a sound (nonleaking) tank, will be sluiced by equipment installed as part of Project W-320 to remove high-heat waste. Based on available waste characterization data and past tank sluicing experience, it is expected that the waste remaining after sluicing may exceed the $\leq 10.2 \mathrm{~m}^{3}\left(360 \mathrm{ft}^{3}\right)$ goal of the Tri-Party Agreement. Technologies and systems different from hydraulic sluicing are expected to be required to remove the residual hard-heel waste.

\subsubsection{Description of Technical Approach}

This section describes the approach to apply the best commercially- available technology for hard-heel waste removal without limiting the technology choice by preselection. The technology for removing residual hard-heel waste from tank 241-C-106 has not been predetermined, but will be based on results from competing commerciallyavailable technologies that are obtainable by competitive bids from private industry. The major performance requirement is to remove sufficient waste to meet or exceed the Tri-Party Agreement requirement. A two-phased approach to obtain the most cost-effective technical solution has been implemented.

1. Evaluation of Commercial Retrieval Technology. The Acquire Commercial Technology for Retrieval (ACTR) industry and other technology developers were solicited to propose alternate technologies for removing waste from SST's. These technologies were evaluated and proof-of-principle tests of the best technologies have been performed. The results of these tests have been disseminated to prospective bidders to support design refinements for tank 241-C-106 waste heel removal.

2. Tank 241-C-106 Waste Heel Removal. After the results of the initial technology evaluations are disseminated, a performance-based competitive bid process will be used to select several vendors to provide preliminary system design plans for qualification testing and cost estimating for tank 241-C-106 hard heel retrieval. One vendor will be selected to test equipment in tank 241-C-106 and provide data on waste removal capability. As part of this hot test, the retrieval system will be used to complete retrieval of the hard-heel waste to comply with the requirement of either $\leq 10.2 \mathrm{~m}^{3}\left(360 \mathrm{ft}^{3}\right)$ residue or the limit of waste retrieval technology capability, whichever is less (Milestone M-45-00). 


\subsubsection{Status of Technology}

Results from the ACTR program indicate that adequate technology for waste retrieval components and integrated systems is available, but that this technology must be tested and tailored to the requirements of waste retrieval from the Hanford Site underground radioactive waste tanks.

\subsection{ESTABLISHING RETRIEVAL PERFORMANCE CRITERIA}

This section describes the approach to obtain agreement on criteria that would complement the establishment of waste retrieval technology capability and form the basis for a final waste retrieval goal for closure of SSTs. This section also describes the HTI approach to resolve closure issues for the AX tank farm, which are identified in the SST closure work plan (DOE-RL 1996a).

One of the primary functions of waste retrieval is to remove sufficient waste from the tanks to allow closure of the tank farms to proceed. The interim retrieval goal specified in Milestone M-45-00 is to leave no more than $10.2 \mathrm{~m}^{3}\left(360 \mathrm{ft}^{3}\right)$ of waste or the limit of retrieval technology capability, whichever is less, in a $23-\mathrm{m}(75-\mathrm{ft})$ dia. SST in order that tank closure can occur. Retrieval technology capability to address Milestones M-45-03 and M-45-04 will be established by the sluicing of and hard-heel waste removal from tank 241-C106. The results from these retrievals will be used to convert the interim retrieval performance goal into a final retrieval goal for tank closure.

Requirements for final closure of waste tanks can be derived from several statutes, regulations, and DOE orders. Regulatory requirements that must be addressed in reaching decisions on tank farm closure and that require prediction of the consequences of contaminant transport from residual waste remaining in tanks and leak-contaminated soil are as follows:

- "National Primary Drinking Water Regulations" (40 Code of Federal Regulations [CFR] 141)

- "Dangerous Waste Regulations" (Washington Administrative Code (WAC) 173-303)

- "Model Toxics Control Act Cleanup Regulations" (WAC 173-340).

If the NRC classifies residual waste in SSTs as "incidental" (non-HLW), then in situ disposal of the radioactive component would require long-term performance assessments in accordance with DOE Order 5820.2A Radioactive Waste Management. Additional requirements may be imposed based on the input of stakeholders and public-interest groups. In addition, issues have been identified in the Single-Shell Tank Closure Work Plan, (DOE-RL 1996a) that must be resolved to close SSTs. 


\subsubsection{Description of Technical Approach}

The technical approach for establishing retrieval performance evaluation criteria that accommodate regulatory requirements, DOE orders, and stakeholder values will be to (1) review and summarize existing documented criteria, (2) invite regulators and stakeholders to participate in technical and programmatic planning, and (3) reach consensus on the retrieval performance criteria. Issues that need to be addressed include, but are not necessarily limited to, the following:

- Determine acceptable tradeoffs among increased occupational risks to workers and reduced risks to the public and environment.

- Determine tradeoffs between risk reductions and associated costs.

- Identify potential conflicts between regulation of hazardous waste and radioactive waste components of the residual waste.

- Quantify qualitative regulatory requirements and stakeholder values to provide a basis for objective comparison of alternatives and associated costs.

- Define an acceptable period and location of compliance for applying quantitative performance criteria.

- Define assumptions relating to future site use and intruder scenarios.

\subsubsection{Status of Technology}

No Hanford Site tanks have been closed under the existing regulatory requirements. Accordingly, the process for tank closure is undefined, except to the extent it is addressed in the Tri-Party Agreement (Milestones M-45-00 and M-45-06) and in the WAC regulations (WAC 173-303-610) for hazardous waste treatment, storage, and disposal units.

\subsection{CONTAMINANT TRANSPORT MODELING}

This section describes the approach that will be used to evaluate long-term risk after tank closure. For tank 241-AX-104, long-term risk would be principally from the migration in groundwater of residual contamination. Information on long-term risk associated with the closure alternatives for tank 241-AX-104 will, in turn, be used in conjunction with information on risk derived from other sources of residual contamination from the Hanford Site to address Defense Nuclear Facility Safety Board Finding (DNFSB) 94-2. This finding advises DOE-Richland Operations Office (RL) to account for the cumulative effects on the environment of multiple sources of contamination and multiple waste disposal actions. 
Evaluating alternatives for waste tank closure and determining readiness for closure will require assessment of the long-term risk to public health or the environment from any residual waste left in the tanks and surrounding soil. Assessment of risk will be based on the following:

- Measurements of the volume and composition of residue remaining in the tank.

- Estimates of associated contamination in the soil around the tank.

- Predictions of the transport of contaminants and the associated risks.

- Identification of closure performance criteria based on regulations, technical analysis needs, and stakeholder input.

\subsubsection{Description of Technical Approach}

Final retrieval requirements that will serve as performance specifications for waste retrieval systems have not been established. Where waste remains in a tank after completion of retrieval, closure of that tank would consist of the actions necessary to immobilize and isolate the residual radioactive and hazardous waste. Determination of those actions will be based, in part, on analyses of risk to the workers, the public, and the environment resulting from alternative closure configurations and approaches. Results of these analyses will be factored into selecting the preferred configuration and approach for tank closure.

The technical approach chosen to analyze risk to the public from long-term transport of contaminants remaining after closure of tank $241-\mathrm{AX}-104$ will be based on predictions from numerical simulations of groundwater flow and contaminant transport in the vadose zone and underlying aquifer. The predictions will be compared with closure criteria derived from applicable regulations and stakeholder values. A near-field model will be used to simulate groundwater flow and contaminant transport in the vadose zone. An intermediate to far-field model will be used to simulate flow and transport through the aquifer underlying the vadose zone and to estimate future health effects.

A one-dimensional flow and transport numerical model, using the MEPAS computer code, will provide an initial screening assessment to estimate sensitivity of overall system performance to source term and transport parameters. A three-dimensional numerical model of AX tank farm will be used as a basis for calibration of a two-dimensional model that will be used to simulate flow and transport above the saturated zone in the AX tank farm. Both the two-dimensional and three-dimensional transport models will use the PORFLOW computer code. The two-dimensional model will evaluate contaminant release and transport through the vadose zone for each alternative and will be used to estimate contaminant concentrations in groundwater between the AX tank farm and the Columbia River, as a function of time and location. This will be used to estimate risks to receptors under postulated site use scenarios. Risk to postulated receptors will be estimated using the GENII computer code. 
HNF-SD-WM-PMP-022, Rev. 0

\subsubsection{Status of Technology}

PORFLOW will be used to compare performance of tank closure alternatives for the HTI because of the following attributes:

- Technical requirements of the simulations

- Critical review of the software's capabilities relative to the capabilities of alternative software and the simulation requirements

- Documented acceptance by pertinent regulatory agencies

- An extensive history of widespread use at DOE and other contaminated sites.

PORFLOW can be used to simulate groundwater flow, heat transfer, and mass transport in 1-, 2-, or 3-dimensional heterogeneous porous and fractured media. In general, PORFLOW provides capabilities to solve contaminant transport problems in multi-phase, multi-component systems. Radionuclide decay chains with up to four members can be employed for analyses of radionuclide transport.

GENII computes doses from a variety of environmental pathways for contaminant release to air or water. The releases may be of short or annualized durations. Doses are computed for contact with groundwater or contaminated soil. MEPAS (trademark) is a physics-based risk-assessment model that estimates public health risks for purposes of relative ranking. Risk values are computed for radioactive and chemical carcinogens and noncarcinogens.

\subsection{RESIDUAL WASTE VOLUME DETERMINATION}

Tri-Party Agreement Milestone M-45-00 establishes the interim near-term tank waste retrieval and tank closure objectives for the Hanford SST farms. An initial interim retrieval goal of $99 \%$ of the waste inventory has been established as the retrieval objective although it is recognized that final waste removal criteria for radionuclides and hazardous constituents will be derived from the ongoing performance assessment activities and the assessment of risk. This initial interim goal for waste removal equates to tank residues not exceeding $10.2 \mathrm{~m}^{3}\left(360 \mathrm{ft}^{3}\right)$ for each 100-Series tank and $0.85 \mathrm{~m}^{3}\left(30 \mathrm{ft}^{3}\right)$ for each 200-Series tank.

The ability to estimate the total volume of residual waste that resides on the tank floor is dependent on measurement techniques to both locate the tank bottom and to map the waste surface. Estimates of residuals in and on pipes and air-lift circulators, on the tank liner ribs and on the dome is highly dependent on accurate dimensional references and robotic technologies able to deploy cameras, mechanical probes and sensors to access hard-to-reach locations. The selection of technologies and the required accuracy of these volume measurements will be driven by its impact on the uncertainty of risk estimates and on the concentrations of key constituents present and their impact on risk. The preliminary 
performance assessment and Data Quality Objective (DQO) for in-tank waste analysis will guide the selection of technology for future deployments to address the waste volume estimate task.

\subsubsection{Description of Technical Approach}

The technical approach for residual waste volume estimates will first be developed and demonstrated at tank 241-AX-104 and the preferred approach then applied to tank 241-C-106 following hard heel removal. The approach for technology selection will be based on the DQO evaluation of risk derived from the preliminary performance assessment and the sensitivity of the volume measurement to risk estimates. This iterative and ongoing evaluation is preliminary and highly dependent on the concentrations of key constituents that still remain in tank $\mathrm{AX}-104$, but have not yet been sampled and analyzed. Therefore, an iterative graded-approach based on the initial DQO risk evaluation will be pursued to guide selection and application of technologies and development of alternative technology acquisition and deployment strategies.

The baseline technical approach for residual waste volume estimates will continue to be based primarily on the use of historical data, available tank structural design drawings, and deployment of commercially-available video camera and stereo video equipment in multiple risers. This information is qualitative and highly dependent on engineering judgment, but will continue to improve the engineering estimates of the waste distribution and assumed volume.

A laser-ruler will be qualified for in-tank applications and deployed with high-resolution cameras to improve distance and dimensional estimates of hardware and waste structures to further improve waste surface topographic maps. A magnetometer will be tested and deployed in multiple risers for direct measurement of waste thickness and will provide a basis for a quantitative waste volume estimate on the tank floor. The LDUA will be deployed with high-resolution video camera equipment to assess waste distribution and volume in hard to reach locations and behind obstructions, e.g., multiple air-lift circulators.

If the risk assessment and DQO evaluation establish that the risk and subsequent decision for waste retrieval and tank closure are highly sensitive to the accuracy of the volume measurement, more complex and expensive technologies will be selected or designed, fabricated and tested, and deployed. An ITS designed to access most of the waste on the tank floor is currently proposed for procurement in fiscal year (FY) 1999. It will be used to assess such waste characteristics as thickness, distribution and heterogeneity, and to sample the waste. If procured and successfully deployed, the ITS will significantly improve the uncertainty of floor location and the waste thickness estimate. Although not currently in the HTI Project's baseline, the TMS is capable of generating highly accurate three-dimensional digital maps of tank internal surfaces, including the waste surface, and could be deployed to generate accurate topographic maps of the waste surface. These technologies would provide complementary information that would significantly improve the accuracy of the residual waste volume estimate. 


\subsubsection{Status of Technology}

Commercially-available and radiation-hardened video camera and stereo camera equipment are currently being used for initial waste volume estimates at Hanford. A commercially-available magnetometer is being tested for deployment as a method of measuring waste thickness. A laser ruler has been purchased and will be qualified for use with high-resolution cameras. The LDUA was developed for Hanford applications by a consortium of industrial partners and the DOE Office of Science and Technology (Tanks Focus Area[TFA]) and has been demonstrated and transferred to the TWRS Project. The LDUA is currently being qualified and approved for deployment in flammable gas tanks. The TMS, also developed by industry and sponsored by the TFA, has been successfully demonstrated at ORNL. It will require a safety and readiness assessment for tank deployment. The procurement of the ITS has not been initiated, but will be open to industry to propose the specific technologies and design for in-tank applications.

\subsection{RESIDUAL TANK WASTE SAMPLING}

Current estimates of the quantities of radionuclides and hazardous chemicals that remain in tank AX-104 are based on historical information and process records. The reliability and accuracy of these estimates are uncertain. However, without actual waste samples and analysis these best estimates provide the only basis for performance assessment models and risk assessment. Actual tank waste sampling and laboratory analysis is the preferred method for providing the quantitative data needed to determine the long-term risk associated with the residual waste and to provide the basis for the waste retrieval and tank closure decisions. Because the confidence level of the characterization data required to support these decisions is not well-established, there is an urgency to retrieve early samples to both validate assumptions made in the preliminary performance assessment and to guide technology selection for future in-tank waste sampling and analysis.

It is estimated that 7,000 gal of high-activity dry residual waste remains in tank AX104 as mostly hard heel on the tank floor $54 \mathrm{ft}$ belowgrade, as well as residues encrusted on the 22 air-lift circulators, drywells, pumps, sluicers, and on the tank liner ribs and dome. There are currently two risers available to access the waste. Additional risers may be needed to retrieve an acceptable minimum number of samples for analysis to estimate both analyte concentrations and spatial variability of the waste and to provide material for water leach tests to establish the solubility limits of key constituents.

The preliminary performance assessment and DQO for in-tank waste analysis will guide the final selection of technology for waste sampling and analysis. The need for more comprehensive sampling and analysis and the selection of alternative technologies to address those needs will be driven by the uncertainty of risk estimates derived from the current residual waste estimates, the current best estimates derived from the current chemicals that remain in the waste, and new data gained from initial sampling, analysis and material testing. 


\subsubsection{Description of Technical Approach}

The baseline technical approach for in-tank residual waste sampling and analysis is driven by the preliminary performance assessment and the initial DQO product. Based on the best available information and risk calculations, the DQO will identify the key analyte contributors to risk and will prescribe the number of samples and analytical requirements, e.g., detection limits, accuracy, and precision, to satisfy an initial risk model. It is recognized that initial recommendations may change as samples are retrieved and analyzed. The initial DQO product will be used to prepare the Sampling and Analysis Plan (SAP) that prescribes the operational detail to support the sampling and analysis campaign.

Because no samples have yet been retrieved and analyzed, the urgency to retrieve early samples using simple, available, and demonstrated tools and equipment guides the baseline characterization strategy. Additional risers are being opened and made available for deployment of simple mechanical samplers. Several generations of auger sampling tools have been fabricated for use in Hanford tanks, but the best designs have not yet been tested to retrieve residual hard waste on tank floors. These tools will be tested and, if successfully demonstrated to retrieve minimum acceptable waste volumes, will be deployed at the earliest possible date to provide a direct measure of analyte concentration, spatial variability of the waste, radioactivity, harcness, and depth of waste. If these tools prove unacceptable, alternative samplers will be identified and acquired, and/or designed, fabricated, and tested prior to deployment.

The LDUA has been deployed as an initial demonstration in tank 241-T-106 and the system has been transferred to the TWRS Project for in-tank characterization tasks. Although the current manipulator design provides for limited waste assessment and sampling tasks on the tank floor, it is the only technology currently available to sample waste that resides on tank liner ribs; air-lift circulators, and the tank dome. Because of its availability and unique capabilities, the LDUA is viewed as a baseline technology for characterization of residual waste in hard-to-reach locations. A sampler end-effector is being designed, fabricated, and tested, and the LDUA is being readied for one initial sampling campaign.

If the initial and/or subsequent DQO evaluations based on risk assessment conclude that more extensive sampling and analysis is required to support the risk-based decisions for waste retrieval and closure, an alternative characterization strategy will evolve. This may involve additional deployments of the baseline technologies and/or the design, fabrication, and testing of more complex and expensive technologies. To reduce the programmatic risk of providing the minimum and sufficient characterization data to support closure decisions, an ITS designed to access most of the waste on the tank floor has been proposed to assess the waste characteristics and to sample the waste. 


\subsubsection{Status of Technology}

Auger sampling tools have been designed and fabricated for use in Hanford tanks, but the latest designs have not been tested for recovery of small amounts of residual waste. These tools will be tested and, if satisfactorily demonstrated, will be deployed in-tank; otherwise, alternative sampler tools will be need to be designed and tested. The LDUA system is also available for use. To improve its capability, an extended reach-end effector is being designed, fabricated, and tested to increase the effective reach by approximately $6.5 \mathrm{ft}$. This extension will enable the LDUA to access, examine, and sample waste from such hardto-reach locations and to sample a larger area of the tank floor. Issues associated with the Unresolved Safety Question (USQ) on flammable gas and provisions for use of the LDUA under the current Authorization Basis are being addressed to ready the LDUA for deployment.

An initial technical specification for design of an ITS, which could be used in tank 241AX-104 has been written. The long-term TWRS Project needs for the ITS in support of both tank waste storage and disposal will be identified in FY 1998. If necessary, the technical specifications will be revised to incorporate newly identified needs and requirements.

\subsection{SOIL SAMPLING AND CHARACTERIZATION}

At least 66 of the Hanford SSTs are known or assumed to have leaked an estimated $750,000 \mathrm{gal}$ of waste. From the performance assessment perspective, the leaked waste from the SSTs could become the prime contributor to future doses depending on the composition and actual amount of waste that has leaked, and the hydraulic and retardation properties of the sediments between the AX tank farm and the water table. In support of waste retrieval and closure decisions, equal importance must be applied to characterization of the residual waste that resides both inside and outside of the tank.

Tank 241-AX-104 is one of the two tanks in the AX tank farm that is assumed to have leaked an estimated 8,000 gal of waste during its process history. Recent analyses of gamma emitting isotopes using borehole geophysical logging tools deployed in multiple dry wells around tank AX-104 suggest contamination through the backfill soil column and into the undisturbed vadose zone. Current best estimates of radionuclide and chemical inventory, which are also based on process history and transfer records suggest that significant releases did occur at or near the surface of the tank.

These best estimates and derived radionuclide and hazardous chemical releases provide the current basis for performance assessment models and risk assessment. Sensors deployed in the soil column that detect the presence of highly mobile radionuclides, e.g., ${ }^{137} \mathrm{Cs}$, are needed to definitively map the extent and configuration of the contamination plume and to validate and strengthen the assumptions in the performance assessment. The preliminary performance assessment and DQO for vadose zone characterization will guide the selection of any additional technology required for vadose zone waste assessment, sampling, and analysis. 


\subsubsection{Description of Technical Approach}

The baseline technical information for modeling the migration of waste assumed to have leaked into the backfill and vadose zone is primarily the hydraulic properties of sediment lithology, groundwater chemistry, and analyte-specific retardation properties of soil sediments. This information is based on historical borehole field investigations and laboratory studies and extrapolated to the AX tank farm field conditions and geologic setting. The volume, composition, and distribution of the leaked waste has been estimated by downhole spectral-gamma logging of the 31 dry wells in the AX tank farm. This information has been analyzed on the basis of process history and transfer records to provide a current bestbasis estimate of the radionuclide and hazardous chemical inventory for the risk assessment.

The baseline technical approach to validate the composition, quantities, and location of contaminants leaked to the backfill and vadose zone is deployment of demonstrated miniaturized sensors, e.g., gamma spectrometer and x-ray fluorescence (XRF), and soil samplers using industry-standard cone penetrometer techniques. The gamma spectrometer will provide conventional gamma logging and the XRF sensor will be used to detect and locate Resource Conservation and Recovery Act of 1976 (RCRA) metals and the presence of highly-mobile constituents, e.g. ${ }^{238} \mathrm{U},{ }^{99} \mathrm{Tc},{ }^{129} \mathrm{I},{ }^{79} \mathrm{Se}$. Discrete soil samples will also be taken to validate sensor performance and for full suite laboratory analysis. Sleeve and tip rheology sensors will also be deployed to classify soils to provide information for contaminant migration studies.

The initial $\mathrm{DQO}$ for $\mathrm{AX}-104$ vadose zone characterization will provide the basis for the SAP. If the DQO evaluations based on the preliminary performance assessment or new characterization information conclude that more extensive characterization of the vadose zone is required, alternative technologies and deployment strategies will be pursued. This may involve the installation of additional boreholes and/or the design of new instrumentation and sensor deployment platform.

\subsubsection{Status of Technology}

The current baseline technology includes metal drywells and boreholes that are drilled or driven into the backfill soil and vadose zone surrounding individual tanks and tank farms. The large-diameter boreholes, already in position around most tanks, are used to periodically monitor the vertical distribution of gamma emitting radionuclides and soil moisture content using neutron and gamma probes. Although not planned for the AX tank farm, installation of RCRA groundwater monitoring wells is a proven technology that allows for measurement of hydraulic properties of sediments, characterization of sediments, installation of flowmeters, long-term monitoring of groundwater, and installation of probes for moisture and radiation measurements. 
Cone penetrometer technology is used extensively in private industry, has been used at Hanford, and has been demonstrated to successfully deploy sensors and samplers in many geologic settings. The Hanford Site cone penetrometer platform designed for TWRS Program applications is available for use in the AX tank farm demonstration. The probe for AX tank farm applications combines demonstrated radionuclide and chemical sensors, sensors to derive soil type, and a metal detector into a single multi-sensor probe. A discrete soil sampler for confirmatory sampler will be fabricated and deployed. 


\subsection{HANFORD TANKS INITIATIVE MANAGEMENT APPROACH}

The HTI Project is sponsored and funded by the DOE and is performed by a senior team comprised of Project Hanford Management Contractor (PHMC) and Pacific Northwest National Laboratory (PNNL) staff. The HTI is part of the PHMC scope and complies with all PHMC policies and procedures. It is project oriented, focused on HTI technical and programmatic objectives, and intent on partnering with regulatory agencies, private industry, and stakeholders. This commitment includes corporate and personnel performance standards that will be reflected by successful completion of the HTI mission.

The HTI organizational structure reflects this management approach through direct lines of authority and responsibility, the commitment to using senior, quality personnel, and a direct line of reporting by the HTI project manager to Lockheed Martin Hanford Company's (LMHC) Vice President for Tank Waste Disposal. The DOE and PHMC have assigned operating authority to the HTI management team, subject only to a reasonable level of oversight and audits. The HTI team is open, responsive, accepting of change, and committed to the successful completion of the technical and project objectives.

\subsection{HANFORD TANKS INITIATIVE PROGRAM ORGANIZATION}

The HTI organization is organized specifically to (1) establish the closure basis for tank 241-AX-104; (2) place tank 241-C-106 in a condition suitable for closure-readiness activities; and (3) complete other supporting technical and programmatic objectives as described in Section 2.1 of the HTI Plan, within five years. The project-oriented nature of the HTI is enhanced by a co-located management team with matrix support as necessary to maximize personnel efficiencies. Personnel have been carefully selected from various Hanford Site organizations and report to the HTI project manager, regardless of the parent organizations from which the team members originated. The HTI Project organization has been designed to maximize communications both internally and externally.

Peer review groups are being used to further strengthen the organization's commitment and ability to achieve its goals. The peer reviews are approved by the project manager and their members recruited from senior levels of DOE, its contractors, national laboratories, and private industry. The peer review groups are chartered to support the project team by reviewing the HTI, advising the HTI team on other methods and options for completing the workscope, or identifying additional resources to achieve the HTI mission objectives.

Figure 3-1 identifies the top-level organizational structure adopted by the HTI Project. In selecting personnel for key positions, a basic premise was that successful leaders consistently meet or exceed assigned objectives by fostering teamwork, safety, environmental and regulatory compliance, quality, cost savings, and schedule compliance. 


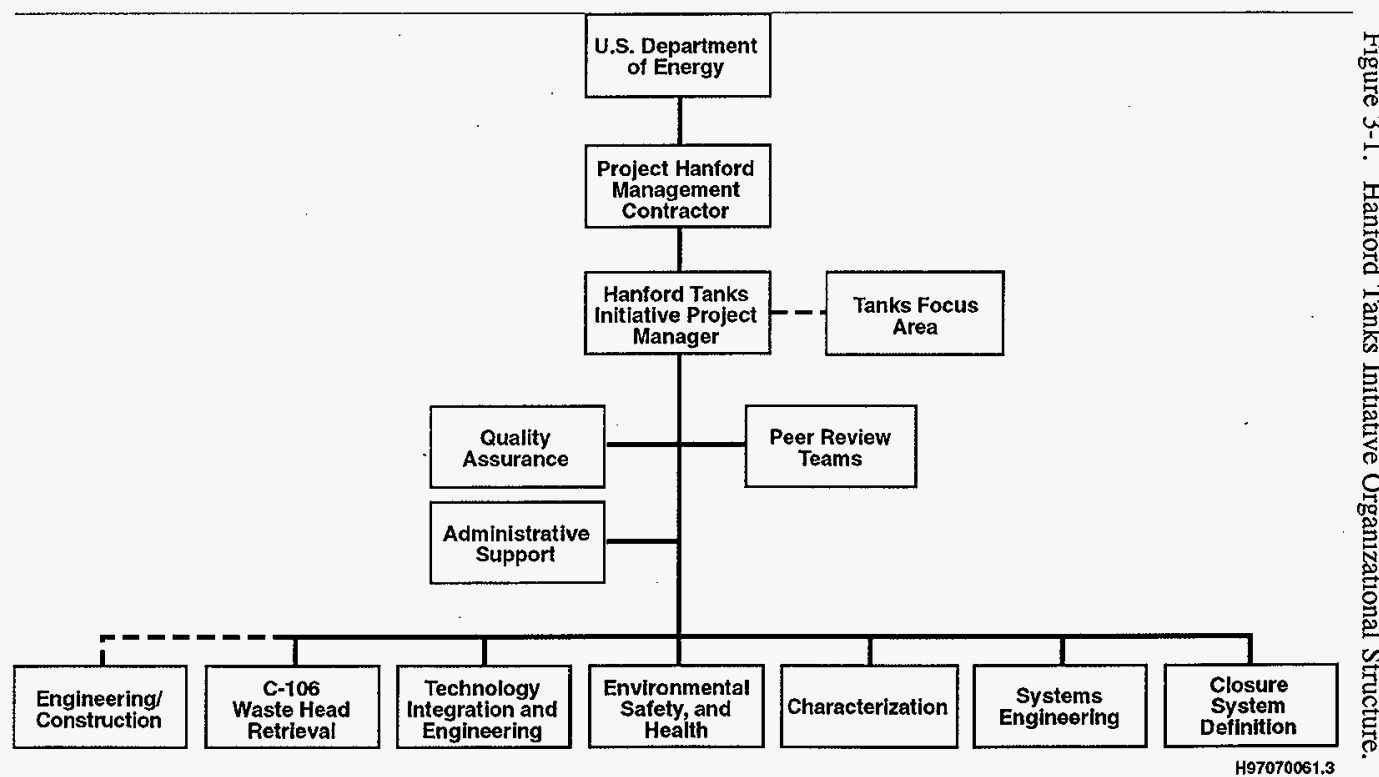

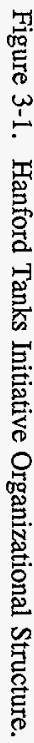


The HTI team fully understands that conflicts or changes in requirements, if not carefully managed, can lead to quality, compliance, or safety issues. The approach to resolving such issues before they lead to problems will be based on the following:

- Compliance with all applicable PHMC policies, procedures, and requirements.

- Adherence to established ground rules and standards of conduct.

- Acceptance of the role as resource stewards on behalf of the stakeholders.

- Effective and timely communication of project status, plans, and strategy to the stakeholders.

- Well-coordinated management of programs by integrating all aspects of environmental, safety and health (ES\&H) and quality assurance (QA) programs with programmatic requirements in the cost, schedule, and technical baselines.

- Integration of the HTI Project with the appropriate external processes and programs.

- Acceptance of the value added by technical peer reviews, particularly in the area of safety.

The HTI organization emphasizes safety, health, and environmental protection by establishing accountability for these responsibilities within line management. Independent overviews and peer reviews are made at appropriate intervals of activities that affect these and other vital project activities, thus ensuring that these aspects are not compromised. Responsibilities of the management and task-performing organizations that help achieve the HTI objectives are defined in the sections that follow.

\subsection{HANFORD TANKS INITIATIVE PROJECT MANAGER}

The HTI Project manager provides overall direction, policy coordination, and broad planning to implement the HTI technical and programmatic objectives. The project manager will ensure the integration of activities and ensure financial and personnel resources are consistent with the mission and objectives. The project manager is also knowledgeable of all peer review and audit activities and their results and monitors any resulting actions. Cost and schedule decisions are consistent with the responsibilities delegated to the project manager. The project manager ensures compliance of the HTI team with all applicable PHMC policies, procedures, and requirements.

The HTI Project manager has final accountability for the success of the HTI Project. Assurance of job safety, quality and compliance is a key focus, as is cost and schedule control. The project manager chairs the HTI Change Control Board, and along with the other HTI personnel, provides the HTI interface with stakeholders. Guidance from the 
regulators and other stakeholders is actively sought out by the HTI Project, which in turn formulate project objectives and criteria.

\subsection{TANK 241-C-106 RETRIEVAL DEMONSTRATION}

The tank 241-C-106 retrieval demonstration group is responsible for planning all activities associated with retrieval of the hard heel of waste and any residual soft sludges in tank 241-C-106. This group, in conjunction with TWRS operations, is establishing a conduct of operations and procedures program consistent with the risk levels indicated by actions to be implemented in tank 241-C-106. They will seek to maximize efficiency and responsiveness for HTI field activities, while at the same time not compromising safety or quality. They are participating in the vendor program conducted by Technology and Integration Engineering and have contributed to the (1) preparation of performance specifications, (2) vendor evaluations and selections, and (3) direct accountability for the vendor's field performance within the TWRS tank farms. They will establish readiness for operation and integration with the TWRS tank farm operation program. A Project Execution Plan for the removal of the waste heel in tank 241-C-106. has been prepared and issued.

Tank waste retrieval will be preceded by a written finding of operations readiness. An Operational Readiness Review Committee will ensure operations are within the Tank Farm Safety Basis. Before startup is allowed to proceed, there will be assurance that (1) construction and installation was completed in an acceptable manner, (2) vendor performance requirements have or can be met, (3) emergency preparedness is in place and all training completed, (4) operating staff is sufficiently knowledgeable, trained, and fully prepared to operate the facility in a safe manner, (5) all interfaces with TWRS are aligned for the HTI startup and operation, and (6) operating procedures have been peer reviewed and approved.

\subsection{TECHNOLOGY INTEGRATION AND ENGINEERING}

The Technology Integration and Engineering (TIE) group is responsible for securing technology and services from industry as needed to achieve the retrieval and closure objectives of the HTI. The acquisition of technology and services was competed to obtain cost-effective, capable resources, including private industry, universities, and national laboratories. Performance specifications for integrated systems, rather than for specific components, were prepared whenever possible.

The technical basis was derived from a systems engineering approach that supports a performance specification. This group is responsible for bid, award, evaluation, and selection of vendors, in addition to overseeing subcontractor work outside the Hanford Site tank farms. Communications with similar acquisition programs throughout the DOE complex (Appendix $\mathrm{C}$ ) have been established and the findings from other sites are being integrated 
into the HTI vendor selection process. All development work for the HTI is approved by the HTI team and implemented only after a performance specification has been prepared and agreed to by both the HTI Project and the technology provider.

\subsection{ENVIRONMENT, SAFETY, AND HEALTH}

The health and safety of the employees and public and protection of the environment is of paramount importance to the HTI Project. The HTI team and its subcontractors and vendors must comply with the requirements set forth in the TWRS Health and Safety Plan (HASP), the TWRS Standards/Requirements Identification Documents (S/RIDS), and the PHMC contractual requirements. All HTI activities are evaluated against the current TWRS authorization basis, which is assumed to be the Basis for Interim Operation (BIO).

The ES\&H lead, who reports directly to the project manager, is responsible for providing support to HTI management in interpreting and implementing safety, health, and environmental requirements. The ES\&H lead ensures independent safety oversight of HTI activities and appropriate and timely evaluation of HTI activities with respect to approved safety authorization documents to support the project schedules. The safety documentation developed by HTI will support the safety basis for future retrieval activities.

The ES\&H lead coordinates preparation of permits, such as air permits, preparation of NEPA/State (of Washington) Environmental Policy Act (SEPA) documents, and NRC submittals in the environmental area. These activities are scheduled to support the HTI deployments.

Any operation that is not in compliance, or that poses unacceptable health, safety, or environmental risks or costs will be suspended and brought into compliance before the activity is resumed. Vendors will be audited for safety and environmental compliance. Readiness assessments of HTI operations at TWRS will be performed in accordance with TWRS procedures and DOE-RL guidance.

\subsection{CHARACTERIZATION}

The HTI Characterization group is responsible for developing the methodologies and performing those tasks required to establish the radionuclide and hazardous chemical inventory, both volume and constituents, of residual waste left in tank 241-AX-104 and its surroundings. This includes: (1) measurement of the residual waste volume in the tank; (2) sampling and analysis of the residual waste in the tank; and (3) ex-tank sampling and analysis in the surrounding tank backfill and soil column following waste retrieval operations. Characterization data are provided as support to the performance assessment modeling for the AX tank farm and development of waste retrieval and tank closure alternatives for the SSTs. 
The HTI Characterization group is also responsible for the sampling and analysis of residual waste left in tank 241 -C-106 following sluicing operations. This activity provides information required to reduce the technical and programmatic risk associated with equipment design for hard heel removal. It will also provide sufficient material for laboratory testing to determine the key physical and chemical parameters required to retrieve, blend, and process the retrieved waste. Following hard heel removal, the optimum set of equipment and methods demonstrated to estimate the volume of residual waste left in tank 241-AX-104 will be applied at tank 241-C-106. This assessment will determine if the residual waste left in tank $\mathrm{C}-106$ meets the retrieval performance objectives.

The characterization data and information collected during the life cycle of the HTI Project will be effectively analyzed, managed, maintained, and made available to technical experts, decision makers, and stakeholders.

\subsection{QUALITY ASSURANCE}

The HTI QA lead is responsible for establishing and imposing the appropriate QA requirements and provisions for the HTI Project, as outlined in the Quality Assurance Program and Implementation Plan (WHC-SP-1131), which has been adopted by the PHMC, approved by DOE, and is required under the 10 CFR 830.120. QA requirements and provisions during the procurement, design, and construction, phases of the HTI Project are defined in the TWRS general project plan WHC-SD-WM-QAPP-018, Tank Waste Projects Quality Assurance Program Plan, and the project specific quality assurance program plan (QAPP). Specific TWRS QA organizational structure and processes covering Operations are contained in the WHC-CM-6-34, Quality Management Plan, and the latest revision to WHC-CM-6-50, TWRS Quality Assurance.

\subsection{SYSTEMS ENGINEERING}

The HTI Systems Engineering lead is responsible for providing the HTI team with the necessary and sufficient set of systems engineering processes and procedures needed to manage the design, acquisition, testing, and operation of HTI systems. Implementation of systems engineering for the HTI Project is based on the TWRS Systems Engineering Management Plan. Each design authority or designee is responsible for establishing the necessary programmatic and technical requirements for the conduct of his work.

The Systems Engineering lead is also responsible for ensuring that imposed requirements are documented and provided to all affected organizations in a timely manner. A change control program is being administered for all technical requirements. Integration at the project level, including scheduling, is maintained to support communications with TWRS Operations, TWRS privatization, TFA program initiatives, related work at other DOE sites, and other programmatic interfaces. 
The HTI Mission Analysis Report, a project-specific Systems Engineering Management Plan, a Configuration Management Desk Instruction, and an Interface Control Plan have been written and issued for the HTI Project. Life Cycle Asset Management (LCAM) Implementation Plans for each of the three technical areas of the HTI Project have also been written and issued. Key decisions for the HTI Project have been identified and their completions are being documented as the decisions are made. A Risk Management Plan is being written and a process for tracking risks to the HTI Project will be implemented. A plan for measuring technical performance will also be written and implemented in FY 1998.

\subsection{CLOSURE SYSTEMS DEFINITION}

The Closure Systems Definition (CSD) group is responsible for providing a common ground between the HTI Project team and the regulatory agencies that will become the basis for cost-effective progress in tank waste remediation, while protecting workers safety, public health, and the environment. Closure System Definition will define the applicable regulatory requirements for tank retrieval performance objectives and evaluate the performance of the HTI against those requirements. Technical support to line management will also be provided wherever line management is directly accountable for implementing and complying with these requirements.

Tank retrieval performance objectives inciude establishing an effective working relationship with the Washington State Department of Ecology (Ecology) and other stakeholders. Through interaction with the stakeholders, the CSD group is responsible for reaching consensus on achieving an optimal balance between worker risk and public health and establishing tank retrieval performance objectives. Issue resolution plans are being developed in concert with the stakeholders to reach mutual agreement on the process, schedule, end-state options, and commitments.

Included in this function are: assessments of performance to determine compliance with tank retrieval performance objectives, interaction with NRC to classify residual waste as "non-HLW," analysis of closure alternatives, preparation of supporting data for NEPA documentation, engineering definition of requirements for tank fill materials, and evaluation and development of technologies for closing tank farms.

\subsection{ADMINISTRATIVE SUPPORT}

Administrative support for the project manager includes procurement, legal, financial and cost analysis, and planning and scheduling. These support personnel report to the HTI Project manager on a functional and operational basis while assigned to the HTI. Administrative support is provided to the HTI Project on an as-needed basis. 
HNF-SD-WM-PMP-022, Rev. 0

This page intentionally left blank. 


\subsection{ACQUISITION PLAN}

This section describes the overall acquisition strategy for procuring technologies, equipment, and services that will be used to support the HTI. Acquisition activities for the HTI have two purposes: (1) provide technologies, equipment, and services for the HTI in a timely, cost-effective manner; and (2) develop contracting methods that will fully integrate utilization of commercial sources and emerging technologies from national laboratories and universities, using the institutional knowledge and skills of the Hanford workforce. Industry will be given a large share of the responsibility to identify and provide technical solutions and will assume a large share of the responsibility and risks for producing the desired results. This approach will obtain the commercial sector's optimal participation in the remediation of Hanford tank wastes.

The HTI's fundamental values, as described in the HTI Mission Analysis, require completing retrieval and closure-readiness activities for the two tanks within five years. Innovation is implicit, both in the acquisition methods and in the technologies. This innovation, in turn, implies that risk must be managed. Therefore, a primary challenge is to achieve a balance between implementing new technologies that have promise in reducing cost or risk and meeting project schedules (Appendix B). If emerging technologies are identified with potentially substantial cost or risk benefits, those technologies that meet HTI needs will be considered if they can be deployed within the constraints of the HTI schedule.

While the aggressive HTI Project schedule is biased in favor of commercially-available solutions, some areas of technology development may remain yet to be defined. Where these gaps exist, the Morgantown Energy Technology Center and the national laboratories, through the TFA, will help provide technologies to fill these gaps and meet the HTI schedule constraints.

The HTI mission can logically be broken into elements involving current "in-house" solutions to full partnerships with industry by implementing performance-based contracts. A primary goal of this approach is to manage technical and programmatic risk within the project's schedule. All sources, whether commercial or national laboratories, will be held to the same performance standards through the use of measurable, well-defined milestones and products.

Acquisition workscope will be defined using a systems engineering process that is biased toward assigning performance responsibility to readily deployable technologies at the highest practical level (i.e., for the largest workscope). Where technologies are well defined and risks can be quantified and are low, turnkey and/or service contracts will be favored. 


\subsection{TANK 241-AX-104 CLOSURE ASSESSMENT}

The schedule for assessing tank 241-AX-104 closure readiness will provide strong incentives to use existing equipment (such as the LDUA and TMS). Additional equipment, such as potential devices for use with the LDUA, will be procured from the most costeffective source that meets the technical requirements. Analytical support for tank retrieval performance objectives development and assessment of closure system performance will be solicited as needed from national laboratories and commercial providers of technical services.

\subsection{ALTERNATE RETRIEVAL TECHNOLOGY}

Retrieval technology risks will be reduced by performing proof-of-principle tests and evaluating equipment and technologies with the help of the TFA and industry, using the groundwork laid by the ACTR Program. Before test data are acquired, a draft RFP and open dialogue with commercial sources will help reduce the contingencies of bidders before the formalized procurement process begins. The HTI is requesting these tests to evaluate potential high-benefit solutions, to disseminate results to industry, and to identify risk areas that may exist in the system, subsystem, or component. For developing technologies that have a potentially large payback in risk or cost reduction, the HTI will define alternative technology acquisition strategies, which later can be implemented if needed.

\subsection{TANK 241-C-106 RETRIEVAL DEMONSTRATION}

After alternative retrieval technologies have been tested and results have been disseminated, the HTI will implement performance-based specifications to acquire commercially-available technology and/or services to retrieve the remaining waste from tank 241-C-106, with the added stipulation that the technology be applicable for use in a leaking tank. A phased procurement process will be used The general process is summarized below.

- The HTI will develop performance-based specifications based on functional subdivisions of the retrieval process and knowledge of commercial and laboratory capabilities. A draft RFP will be routed to potential bidders for comment, comments will be considered, and a single RFP will prepared and issued.

- Responses will be reviewed and the HTI source selection board will evaluate the proposals based on well-defined proposal evaluation criteria. Two qualified sources will be contracted on a fixed-cost basis to show the capabilities of their equipment and processes through system definition.

- Based on evaluation of the technical submittals from the two vendors, one will be selected to proceed with a cold (out-of-tank) demonstration and hot (in-tank) test to retrieve the remaining waste from tank $241-\mathrm{C}-106$. It is expected that costreimbursable service contracts will be utilized to complete the retrieval effort. 
Fixed-price service contracts (i.e., payment made for the delivery of a tank cleaned in compliance with the closure criteria) may be difficult to award for the first tank, depending on the amount and quality of waste characterization data available for pre-operation and post-operation evaluations. For service contracts, it is anticipated that the labor mix (Site labor versus vendor labor) and its organization will be of critical importance to the success of the retrieval effort.

- Equipment required for site infrastructure modifications to provide an integrated retrieval system for the hot test will be procured using traditional fixed-price contracting methods. Construction activities associated with installation of equipment may be performed using either vendor-supplied labor or PHMC subcontractor labor.

In general, the HTI will seek to implement contracting strategies with the lowest risk to the project mission. Good business practices require competition, with selection being made from more than one qualified source wherever possible. The TFA and ACTR will provide essential knowledge of technology performance. The HTI can rely on ACTR's previous efforts to solicit expressions of interest, thereby providing pre-screened sources and avoiding some of the delays associated with unfocused solicitations. Some vendors may propose fixed-price contractors based upon their degree of confidence. 
HNF-SD-WM-PMP-022, Rev. 0

This page intentionally left blank. 


\subsection{CLOSURE STRATEGY}

\subsection{FRAMEWORK FOR STRATEGY}

There are 149 SSTs on the Hanford Site that store wastes produced by defense materials production. Of these SSTs, 133 have a $23-\mathrm{m}$ dia. $(75-\mathrm{ft})$ and capacities ranging from $2,000 \mathrm{~m}^{3}(530,000 \mathrm{gal})$ to $3,800 \mathrm{~m}^{3}$ (1 Mgal) (100-Series tanks). Sixteen of the SSTs have a 6-m dia. (20-ft), and a capacity of $210 \mathrm{~m}^{3}(55,000 \mathrm{gal})$ (200-Series tanks). These 149 SSTs are located in 12 tank farms, which contain 4 to 18 SSTs per tank farm. The 12 tank farms comprise 6 operable units, with 1 to 3 tank farms per operable unit. The $\sim 136,000 \mathrm{~m}^{3}$ (36 Mgal) of waste in SSTs, consisting of sludge, salt cake, supernate, and interstitial liquids, will be retrieved to the extent needed to close the tank farm operable units.

Upon completion of SST waste retrieval operations, residual waste will remain in tanks and waste that has leaked from tanks will reside in the underlying soil or in the aquifer. This residual waste will have radioactive and nonradioactive hazardous constituents. Management and disposal of the radioactive constituents must comply with federal regulations derived from the Atomic Energy Act of 1954. Management and disposal of hazardous constituents must comply with Washington State regulations derived from the RCRA. Criteria for closure of tank farms impacts retrieval performance specifications relating to how much waste must be removed from tanks, how much waste may leak to the soil during retrieval operations, and removing tank internal hardware.

Milestone M-45-00 establishes an objective to retrieve as much waste as technically possible, with tank waste residues not to exceed $10.2 \mathrm{~m}^{3}\left(360 \mathrm{ft}^{3}\right)$ in each 100-Series tank; $0.85 \mathrm{~m}^{3}\left(30 \mathrm{ft}^{3}\right)$ in each 200-Series tank, or the limit of waste retrieval technology capability, whichever is less. Collectively, these quantities correspond to $\sim 1 \%$ of the total current SST waste volume. Interim Milestone M-45-06 requires periodic submittal of a Single-Shell Tank Closure Work Plan (DOE-RL 1996a) documenting the work integration process and status, and to address issues relating to tank farm closure. The SST closure work plan will serve as a precursor to the actual closure plan for the first SST farm or SST operable unit. The SST closure work plan identifies, among others, an issue related to the percent waste retrieval required to close SSTs. M-45-06 target milestones require submittal of a closure plan for the first SST farm to be closed by November 2004, initiation of closure of the first tank farm by 2012 , and completion of closure of the first tank farm by 2014 .

Milestones M-45-00 and M-45-06 require closure of all SSTs by September 2024. It has not been established that the $99 \%$ overall waste retrieval goal, as defined in Milestone M-45-00, will be sufficient to allow closure of individual tanks or tank farms. The TWRS Environmental Impact Statement (EIS) (DOE-RL 1996b), which addresses remediation of tank wastes, excludes tank farm closure from its scope on the basis that insufficient information presently exists to select a preferred option from among the alternatives identified. 


\subsection{CLOSURE ALTERNATIVES}

Differences among the three closure alternatives identified in the TWRS EIS (clean closure, modified closure, and landfill closure) relate principally to standards for allowable residual soil contamination, the need for surface protective covers, and duration of the postclosure monitoring period. Under the Hanford Site RCRA Permit approved by Ecology, the contamination allowed to remain in the soil is specified for clean and modified closure designations. Where tanks have leaked, clean closure or modified closure would probably require some soil remediation.

Under clean closure or modified closure designations, it is uncertain whether residual waste may be left in tanks or whether tanks may be left in place. Similarly, under a landfill closure designation, it is uncertain whether decontamination and removal of tanks may be required. Regardless of whether tank farms are closed under a clean closure, modified closure, or landfill closure designation, there currently are no quantitative closure standards defined for tank structures and liners per WAC 173-303 regulations or the Hanford Site RCRA Permit. WAC 173-303-610 (2)(a) closure performance standard applies to all three closure designations. This standard requires that the facility be closed in a manner that "controls, minimizes or eliminates, to the extent necessary to protect human health and the environment, the postclosure escape of dangerous waste, dangerous constituents, leachate, contaminated run-off, or dangerous waste decomposition products to the ground, surface water, groundwater, or the atmosphere."

As a basis for closure planning, budgeting, and technology development, it is necessary to know whether the following actions must be performed:

- Remediation of contaminated soil

- Removal of residual waste in tanks following waste retrieval

- Removal of tanks.

If it is assumed that remediation of contaminated soil underlying tanks is possible without first removing the tanks and a surface protective barrier will be constructed in all cases. Six combinations of remedial action alternatives that directly affect waste retrieval specifications are as follows:

1. Remediate soil, remove residual waste from tanks, and remove tanks

2. Remediate soil, remove residual waste from tanks, and stabilize tanks with engineered fill

3. Remediate soil, leave residual waste in tanks, and stabilize tanks with engineered fill

4. Do not remediate soil, leave residual waste in tanks, and stabilize tanks with engineered backfill material 
5. Do not remediate soil, remove residual waste from tanks, and remove tanks

6. Do not remediate soil, remove residual waste from tanks, and stabilize tanks with engineered fill.

Different combinations could apply to closure of different tank farms or operable units.

\subsection{STRATEGY FOR CLOSURE OF ALL SINGLE-SHELL TANK FARMS}

The strategy for reaching final decisions on closure of all SSTs is addressed in DOE-RL (1996a). The closure strategy assumes that waste retrieval operations will remove sufficient waste from SSTs and that the waste residues after retrieval, the SSTs themselves, tank farm ancillary equipment, and contaminated soil will be considered to be non-HLW by the NRC and hence, may be disposed in place in accordance with applicable regulations and agreements. Decisions on general closure configuration and approach will be reached through a process consistent with the NEPA. The closure strategy assumes this process will occur by preparing a supplement to the TWRS EIS.

Several factors will be considered when making final decisions on closure. Quantifiable or worthy factors affecting these decisions include the following:

- Characterization of radioactivity and chemical content

- Long-term contaminant transport to the environment

- Short-term risk to the public and environment (during closure)

- Long-term risk to the public and environment (following closure)

- Accident and health risk to workers (during closure)

- Compliance with applicable regulations and DOE orders

- Cost and schedule.

Cost/benefit analyses (i.e., quantification and comparison of estimated costs and benefits), while not commonly a factor in regulatory compliance, is a well-founded approach used traditionally in the private sector for making decisions on capital investment and funding of research and development activities. To the extent that implementation of closure alternatives would result in quantifiable differences in risk reduction and/or differences in cost, cost/benefit analyses can facilitate the decision process. Factors other than those listed above, although nonquantifiable, also will be important in the decision process. Tradeoffs between these factors will likely be weighed differently by the different decision makers and the groups they represent.

The closure process strategy will include the quantifiable information previously listed, which will be important to the decision makers and provide support of the decision process in a timely manner. This strategy necessitates an early focus on engineering studies, sampling and characterization, contaminant transport modeling, and development of risk analyses methods as a basis for evaluating closure alternatives. 
The overall closure strategy is based on the assumption that the tank waste remediation alternative ultimately selected through the NEPA process and the TWRS EIS will involve retrieving as much waste as practicable from the SSTs, but that residual waste will remain in the tanks following completion of waste retrieval. Development of the preferred closure configuration will be integrated with other established processes within TWRS. These include planning and budgeting, systems engineering, safety analysis, acquisition of environmental permits, NEPA, waste characterization, and technology development.

\subsection{STRATEGY FOR DEVELOPING RETRIEVAL PERFORMANCE CRITERIA}

In August 1996 Ecology and the DOE signed a Memorandum of Understanding (MOU) that committed to ultimately establish a final retrieval goal for the SSTs following completion of the retrieval technology demonstrations under Tri-Party Agreement interim milestones $\mathbf{M}$ 45-03 and M-45-04. This MOU also committed to consider such factors as cost, technical practicality, worker risk, and long-term risk to the public, along with retrieval technology capability, as a basis for establishing a final retrieval goal for SST closure. The MOU committed to seek stakeholder and Tribal Nations input in developing such retrieval performance evaluation criteria for $\mathrm{AX}$ tank farm.

Tank 241-AX-104 represents a SST that has been sufficiently sluiced and could potentially comply with closure criteria under remedial action alternatives 3 or 4 (see Section 5.2). Tank 241-AX-104 has been selected for development and testing of technologies to characterize readiness for closure. It will also be used as a model tank for resolution of closure issues and assessment of retrieval performance criteria that accommodate regulatory requirements, stakeholder values, and program needs.

An engineering study to develop retrieval performance evaluation criteria for the $A X$ tank farm will evaluate combinations of retrieval and closure alternatives, including alternatives involving soil excavation, in situ soil remediation, and tank removal. Evaluations will be made relative to cost, health and safety risk, technical practicability, impacts on waste processing operations and other factors. Stakeholders and regulatory agencies will be involved in identifying and evaluating alternative retrieval and closure options, and translating stakeholder values into a means for comparing alternatives. Results of this study will be used in a subsequent NEPA process for closure of the tank farms and will potentially provide the opportunity for early reduction of retrieval program risk by eliminating some retrieval and closure options that are determined not to be viable.

Subject to refinement by stakeholders and Tribal Nations, the representative set of end state alternatives that will be evaluated under the HTI Project include:

1.) Retrieve waste to the Tri-Party Agreement interim goal $\left(360 \mathrm{ft}^{3}\right)$ with a nominal amount of retrieval leakage $(8,000 \mathrm{gal}$ assumed to be the maximum detectable level per tank). Stabilize tanks with an engineered fill. Construct a RCRAequivalent surface barrier. 
a.) Same as 1.), except assume maximum credible leakage of 40,000 gal per tank during retrieval.

b.) Same as 1.), except with no residual waste, to reflect best possible retrieval system performance.

c.) Same as 1.), except with $3,600 \mathrm{ft}^{3}$ of residual waste per tank to reflect poor retrieval system performance.

d.) Same as 1.), except with a Hanford engineered surface barrier for longer life and lower infiltration rate than with the RCRA-equivalent barrier.

e.) Same as 1.), except with the addition of a temporary surface barrier to limit infiltration during the pre-closure period.

2.) Same as 1.), except with the addition of in-place remediation of contaminated soil.

a.) Same as 2.), but with an assumed leakage of 40,000 gal per tank, represent maximum credible leakage during retrieval.

3.) Retrieve waste to the Tri-Party Agreement limit $\left(360 \mathrm{ft}^{3}\right)$ with nominal retrieval leakage ( 8,000 gal per tank). Remove tanks. Excavate and dispose contaminated soils in an onsite engineered facility. Replace excavated soil with clean fill.

4.) Same as 3.), except with in-place soil remediation, rather than excavation.

5.) Same as 3.), except with no soil remediation and with placement of a RCRAequivalent surface barrier.

In addition to these alternatives, which are intended to provide a representative set of cases involving engineered configuration options for tanks, contaminated soils, and surface barriers, coupled with variables regarding retrieval system performance (residual waste volume and leakage volume), a range of options for remediation of tank farm ancillary equipment will also be considered. Ancillary equipment options are anticipated to include a) leave as is; b) grout in place; c) remove for disposal in an engineered facility on site; and d) remove for disposal in emptied SSTs. Options for ancillary equipment will be coupled with appropriate options for tanks, contaminated soils, and surface barriers to constitute a representative set of end state alternatives for $\mathrm{AX}$ tank farm. These alternative combinations will then be evaluated and compared relative to short-term risks (to workers and the public), long-term risks, life-cycle costs, technical feasibility, and regulatory compliance. 
Probably the most crucial activity necessary to conduct the evaluation and comparison of alternatives is to establish criteria that will be used to define final retrieval performance criteria. This work includes identifying applicable and appropriate criteria that protect the public, environment, and workers, as well as an approach for determining acceptable tradeoffs among these criteria, and benefit and cost. Related tank closure demonstration initiatives at SRS and ORNL will be monitored closely for applicability of its criteria development and waste retrieval performance approaches.

The planned activities for applying residual waste characterization technology and assessing closure readiness will support definition of retrieval performance criteria. The performance evaluation criteria will consider cost, technical practicability, exposure to radiation, and NRC requirements as factors in specifying how much waste must be removed from tanks before closure. 
HNF-SD-WM-PMP-022, Rev. 0

\subsection{INVOLVEMENT OF REGULATORY AGENCIES}

\subsection{OBJECTIVE}

The HTI must accomplish several objectives with respect to fostering the participation of regulatory agencies.

- Involve the regulatory agencies early.

- Ensure that required permits are obtained and regulatory processes are completed in time to support the project schedule.

- Identify opportunities to streamline the regulatory process.

- Obtain an NRC determination of waste classification for residual waste in the soil, tanks, and ancillary equipment.

\subsection{PROCESS AND FRAMEWORK}

The scope of the HTI will involve several regulatory agencies. The major agencies are the Ecology, the Washington State Department of Health (WDOH), the U.S. Environmental Protection Agency (EPA), and the NRC.

Ecology has regulatory authority to enforce RCRA compliance. The SSTs are regulated under RCRA as treatment, storage, and disposal units and must be operated, cleaned, and closed in compliance with RCRA. In addition, Ecology has regulatory authority for some airborne emissions. The county pollution control authorities have local regulatory authority for airborne emissions.

The WDOH has the authority to enforce the Clean Air Act for airborne radioactive emissions. It is anticipated that tank waste retrieval and closure operations will generate airborne radioactive emissions that must be controlled in compliance with the Clean Air Act.

The EPA has delegated regulatory authority for major portions of RCRA to Ecology, but has maintained authority for Land Disposal Restriction (LDR) wastes. Current tank farm permits have identified LDR wastes as being stored.

The NRC has regulatory authority for disposal of all HLW and commercial LLW. Some wastes within tank farms are considered to be HLW subject to NRC authority for disposal. The classification of residual waste, tanks, and equipment will be discussed with the NRC and a proposal made to classify this waste as "incidental" (i.e., non-HLW). 
The number and scope of regulatory permits to be secured for the HTI will depend on the technologies used. The Permitting Plan for Hanford Tanks Initiative, HNF-SD-HTI-EV-001, Rev. 0, issued on February 10, 1997, provides estimates the HTI workscope and applicable permits and related documentation needed. It was assumed that the following actions will be required:

- Cultural resources review

- Endangered Species Act compliance

- NEPA (Environmental Assessment [EA] and Finding of No Significant Impacts [FONSI] or Supplemental EIS) for preparation of tank 241-AX-104 for closure (not in current HTI scope and schedule)

- Pre-operational monitoring of facilities and site

- SEPA environmental checklist

- National Emission Standards for Hazardous Pollutants permit (NESHAP)

- Radiation protection air permit

- New Source Toxic Air Pollutants (TAP)

- RCRA Tank Closure Plan (not presently included in the HTI scope and schedule)

- NRC determination of waste designation for in-tank and leaked waste, and waste associated with ancillary equipment.

Permit application activities that appear to have the greatest potential for affecting the HTI Project schedule are the clean air permits (NESHAP and TAP).

Schedules for preparing and approving air permits have been generated and included in the baseline HTI schedule. The permitting activities have been planned closely with key HTI activities to minimize schedule impacts. RCRA closure plan preparation is estimated to take approximately one year, but is not presently included in the HTI scope and schedule because it is constrained by waste retrieval in the first tank farm, in accordance with the Tri-Party Agreement. Establishing retrieval performance criteria is currently being addressed with Ecology and will involve stakeholder participation (Section 7.0). 
Several strategies exist for carrying out air permit activities to minimize scope and schedule impacts for both HTI and future retrieval and closure actions. These strategies will be reevaluated upon HTI Project completion. The strategies include the following:

1. Examine the air permits generated for Project W-320, 241-C-106 sluicing retrieval, and deployment of the LDUA for application to tank 241-C-106 hard-heel waste removal and tank 241-AX-104 closure-readiness activities.

2. Ensure that any modifications to the tank ventilation/exhaust systems are not needed for the first 18 months of the HTI Project by conducting cold tests outside the tank farms.

The HTI presents several opportunities to streamline the regulatory process. The HTI could provide an "umbrella" permit for future tank waste retrieval actions. The waste in tanks 241-C-106 and 241-AX-104 represents a considerable range of conditions that, along with the retrieval and closure-readiness activities, will cover the scope of several future retrieval and closure activities. The HTI Project will evaluate the advisability of ensuring that the scope of several of the permits is sufficiently broad to cover future waste retrieval and tank farm closure activities. The following will be specifically evaluated:

- Potential to consolidate regulatory authority

- Use of a master template for permits associated with future tank waste retrieval and closure activities

- Use of risk and cost analyses for future NEPA closure analyses.

The HTI Project will request a determination of waste classification (non-HLW) for residual in-tank waste and contaminated soil. This determination will be necessary to establish the applicable regulatory authority for disposal of the radionuclides. This effort will monitor progress on a request for NRC determination being prepared by the TWRS storage and disposal project. The HTI will work in cooperation with other DOE sites that expect to encounter similar issues. 
HNF-SD-WM-PMP-022, Rev. 0.

This page intentionally left blank. 
HNF-SD-WM-PMP-022, Rev. 0

\subsection{STAKEHOLDER INVOLVEMENT}

The HTI represents an important initial step towards closure of tank farm operable units. The HTI will provide needed information to DOE, regulatory agencies, and stakeholders to define future waste retrieval and tank closure actions. The programmatic contribution of the HTI will provide a process and framework to jointly determine the information required to establish retrieval performance criteria. Regulatory agencies and stakeholders will provide guidance to DOE and the technology providers or technical services about the information needed to formulate retrieval performance criteria and subsequent actions to close the tanks. The DOE and its technology providers will, in turn, acquire the data deemed pertinent to establishing those criteria, and the technical and programmatic initiatives needed to actually close a tank.

Several issues have been identified that require resolution before closure of tank farm operable units can proceed. Issues relevant to the HTI include future land use, residual tank contamination, and soil remediation. These issues were identified in DOE-RL (1996a). The public exchange of values and information expected during the life of the HTI (Table 7-1) will be used as input to the DOE and Washington State agencies for NEPA and SEPA determination of the final closure process for Hanford Site waste tanks.

The interactions with stakeholders also will influence permit conditions and future development and deployment of technologies.

The HTI will utilize communications networks at Hanford established by EM-30 and EM-50 activities. The Hanford STCG, Hanford Advisory Board (HAB), public notices, comment periods, and workshops will be used to establish and negotiate expectations and requirements, and to exchange information.

The STCG contains members of DOE EM-30 (Waste Management) and EM-50 (Office of Science and Technology Development), Ecology, Yakima and Nez Perce Indian Nations, the State regulatory community, and public interest groups that have an interest in remediation activities at the Hanford Site. The HAB and several of its subcommittees provide a communication pathway for most Hanford Site interest groups. Additional efforts will be necessary to reach out to interested parties that are not active in the above organizations. Such outreach will be accomplished by public meetings, responses to public comments, workshops, and status bulletins. The EM-50's Community Leaders Network will play an important role in communicating with the public and representing the interests of less organized stakeholders. 
Table 7-1. Stakeholder Involvement.

\begin{tabular}{|l|l|c|}
\hline \multicolumn{1}{|c|}{ Subject } & \multicolumn{1}{|c|}{ Audience } & Time \\
\hline $\begin{array}{l}\text { Debriefing on DOE-Headquarters HTI } \\
\text { discussions }\end{array}$ & $\begin{array}{l}\text { STCG, Ecology, HAB, } \\
\text { Community Leadership Network }\end{array}$ & FY 1996 \\
\hline HTI status briefings & $\begin{array}{l}\text { STCG, Ecology, HAB, } \\
\text { Community Leadership Network }\end{array}$ & $\begin{array}{c}\text { To be } \\
\text { determined }\end{array}$ \\
\hline Closure approach & Ecology, HAB, Indian Nations & FY 1997/1998 \\
\hline $\begin{array}{l}\text { Agreements on retrieval performance } \\
\text { criteria and performance evaluation } \\
\text { bases for closure }\end{array}$ & Ecology, , Indian Nations & $\begin{array}{c}\text { To be } \\
\text { determined }\end{array}$ \\
\hline $\begin{array}{l}\text { Waste retrieval permit applications } \\
\text { and comments }\end{array}$ & Ecology, WDOH, HAB, public & $\begin{array}{c}\text { To be } \\
\text { determined }\end{array}$ \\
\hline & & FY 1997/1998 \\
\hline Technologies to implement & $\begin{array}{l}\text { EM-30, STCG, Industry, } \\
\text { Ecology, HAB }\end{array}$ & FY 1998-2000 \\
\hline $\begin{array}{l}\text { Evaluation of technologies to meet } \\
\text { clean-out criteria }\end{array}$ & STCG, Ecology, HAB, Industry \\
\hline $\begin{array}{l}\text { Evaluation of HTI results for use in } \\
\text { future closure activities }\end{array}$ & STCG, HAB, Ecology & $\begin{array}{c}\text { To be } \\
\text { determined }\end{array}$ \\
\hline
\end{tabular}

Ecology $=$ Washington State Department of Ecology

$\mathrm{FY}=$ Fiscal Year

$\mathrm{HAB}=$ Hanford Advisory Board

HTI $=$ Hanford Tanks Initiative

STCG $=$ Site Technology Coordinating Group, Tank Subgroup

$\mathrm{WDOH}=$ Washington State Department of Health. 


\subsection{SYSTEMS ENGINEERING PROCESS}

Project management and other project participants have the responsibility to know and understand the project mission, needs, functions, requirements, and constraints. The process for developing this understanding is provided through the discipline of systems engineering. The systems engineering process will be conducted internal to and specifically for the HTI Project, but will be directly linked to the TWRS Program and sitewide systems engineering efforts. Appropriate levels of systems engineering expertise needed to implement the systems engineering process and develop the systems engineering procedures will be acquired. However, it is the goal of HTI systems engineering to infuse the systems engineering process and procedures into the fabric of the HTI Project as a part of the way its business is conducted. As such, the project manager and the technical leads will be responsible for ensuring that work conducted by others complies with the systems engineering requirements. It is the responsibility of HTI Project participants to transmit the requirements they impose and ensure that the recipients understand these requirements.

The HTI utilizes systems engineering as defined by the TWRS Program. The Tank Waste Remediation System Systems Engineering Management Plan (Peck 1996) describes the implementation of the DOE-RL systems engineering policy. The Tank Waste Remediation System Systems Engineering Management Plan defines the products, processes, organization, and procedures used by TWRS to accomplish systems engineering objectivesm, and uses a graded-approach that allows the level of detail in the systems engineering process to be tailored to a specific effort. Using this philosophy, a project-specific Systems Engineering Management Plan for the HTI Project has been written and issued (Schaus 1997). 
HNF-SD-WM-PMP-022, Rev. 0

This page intentionally left blank. 


\subsection{REFERENCES}

40 CFR 61, "National Emission Standard for Hazardous Air Pollutants (NESHAP)," Code of Federal Regulations, as amended.

Atomic Energy Act of 1954, 42 USC 2011 or 2114 et seq.

Barnett, D. B., J. D. Davis, H. Hampt, J. W. Lindberg, and K. F. Donnelson, 1996, Subsurface Characterization to Support the Closure-Readiness Demonstration for Tank 241-AX-104, WHC-SD-WM-WP-337, Rev. 0, Westinghouse Hanford Company, Richland, Washington.

Comprehensive Environmental Response, Compensation, and Liability Act of 1980, 42. USC 9601 et seq.

DOE-RL, 1996a, Single-Shell Tank Closure Work Plan, DOE/RL-89-16, Rev. 1, U.S. Department of Energy, Richland, Washington.

DOE-RL, 1996b, Tank Waste Remediation System Environmental Impact Statement, DOE/EIS-0189D, U.S. Department of Energy and Washington State Department of Ecology, Richland, Washington.

Ecology, EPA, and DOE, 1994, Hanford Federal Facility Agreement and Consent Order, as amended, Washington State Department of Ecology, U.S. Environmental Protection Agency, and the U.S. Department of Energy, Olympia, Washington.

Ecology, 1996, Washington State Department of Ecology Endorses the Hanford Tank Initiative Joint U.S. Department of Energy EM50/EM30 Retrieval and Closure Demonstration Project, letter from Mike Wilson, Manager Nuclear Waste Program, to Jackson Kinzer, Assistant Manager, U.S. Department of Energy, Richland, Washington (dated May 1, 1996), State of Washington Department of Ecology, Kennewick, Washington.

Knutson, B. J., 1995, TWRS Mission Analysis, WHC-SD-WM-MAR-008, Rev. 0, Westinghouse Hanford Company, Richland, Washington.

National Environmental Policy Act of 1969, 42 USC 4321 et seq.

Peck, L. G., 1996, Tank Waste Remediation System Systems Engineering Management Plan, WHC-SD-WM-SEMP-002, Rev. 0, Westinghouse Hanford Company, Richland, Washington.

Resource Conservation and Recovery Act of 1976, 42 USC 6901 et seq.

State (of Washington) Environmental Policy Act, RCW 43.21C. 
Tennessee, EPA, and DOE, 1992, Oak Ridge Federal Facility Agreement, Tennessee Department of Oversight and Conservation, U.S. Environmental Protection Agency, and U.S. Department of Energy, Oak Ridge, Tennessee.

WAC 173-303-610, "Dangerous Waste Regulations," Washington Administrative Code, as amended.

WAC 173-340, "Model Toxics Control Act Cleanup Regulation," Washington Administrative Code, as amended. 
HNF-SD-WM-PMP-022, Rev. 0

\section{APPENDIX A}

\section{HANFORD TANKS INITIATIVE WORK BREAKDOWN STRUCTURE}


HNF-SD-WM-PMP-022, Rev. 0

This page intentionally left blank. 


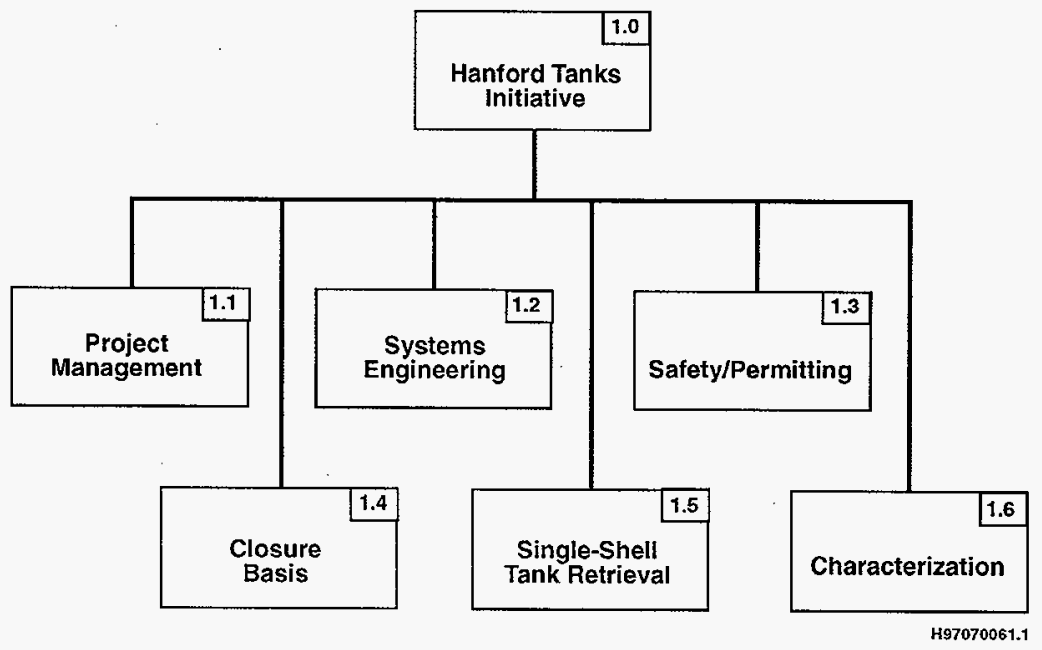


HNF-SD-WM-PMP-022, Rev, 0

This page intentionally left blank. 
HNF-SD-WM-PMP-022, Rev. 0

APPENDIX B

HANFORD TANKS INITIATIVE DETAILED SCHEDULES

B-i 
HNF-SD-WM-PMP-022, Rev. 0

This page intentionally left blank.

B-ii 


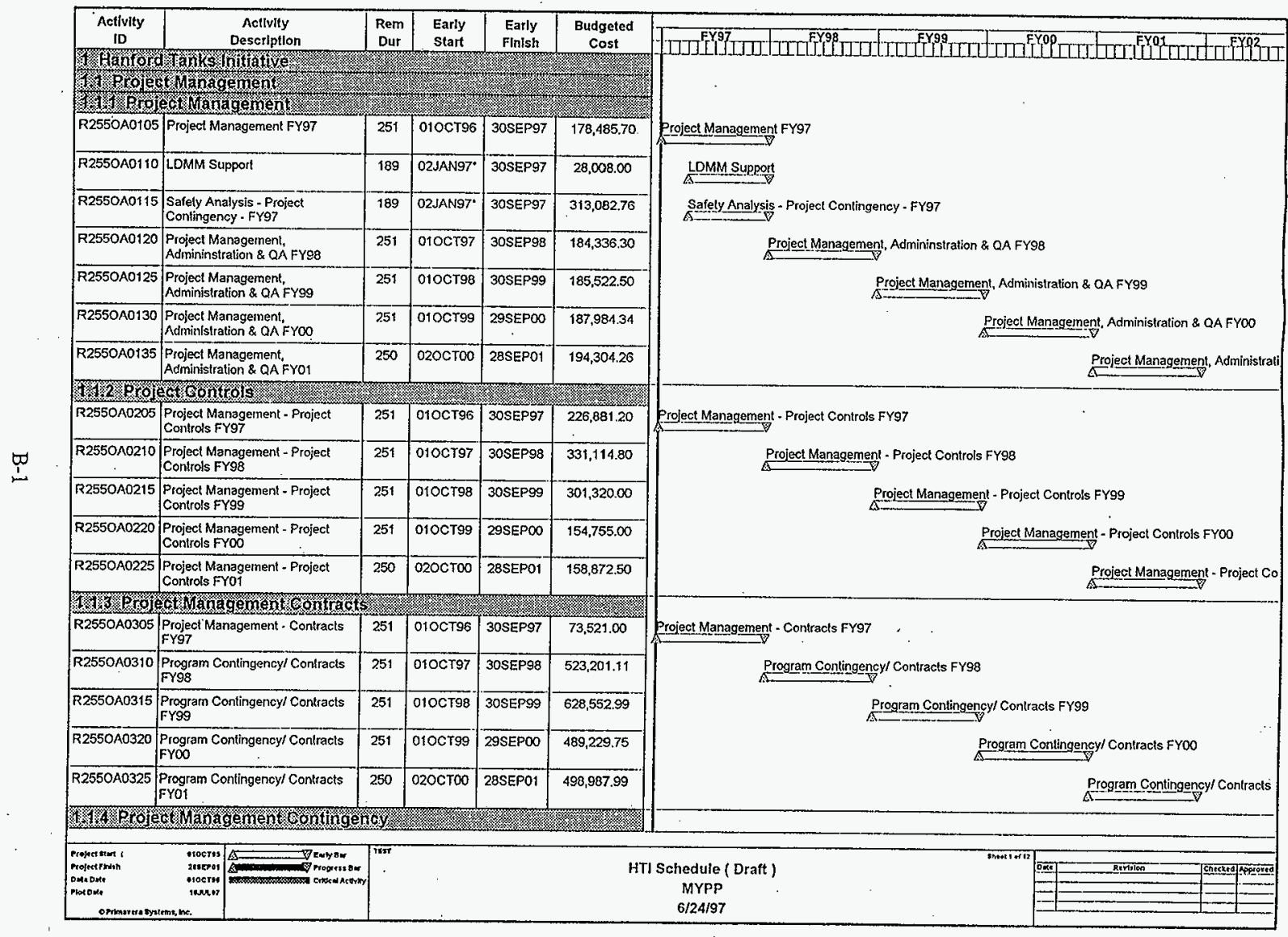




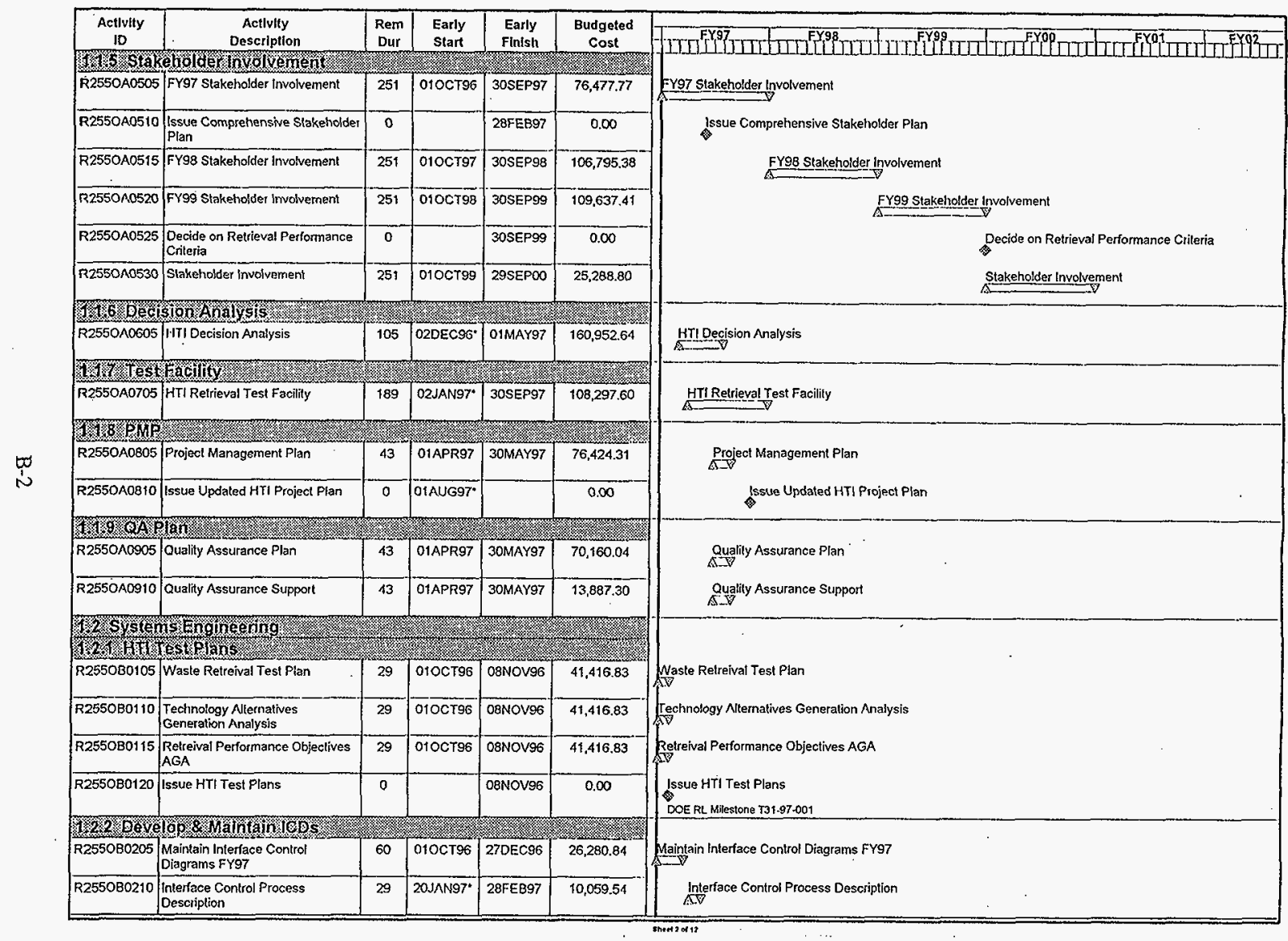




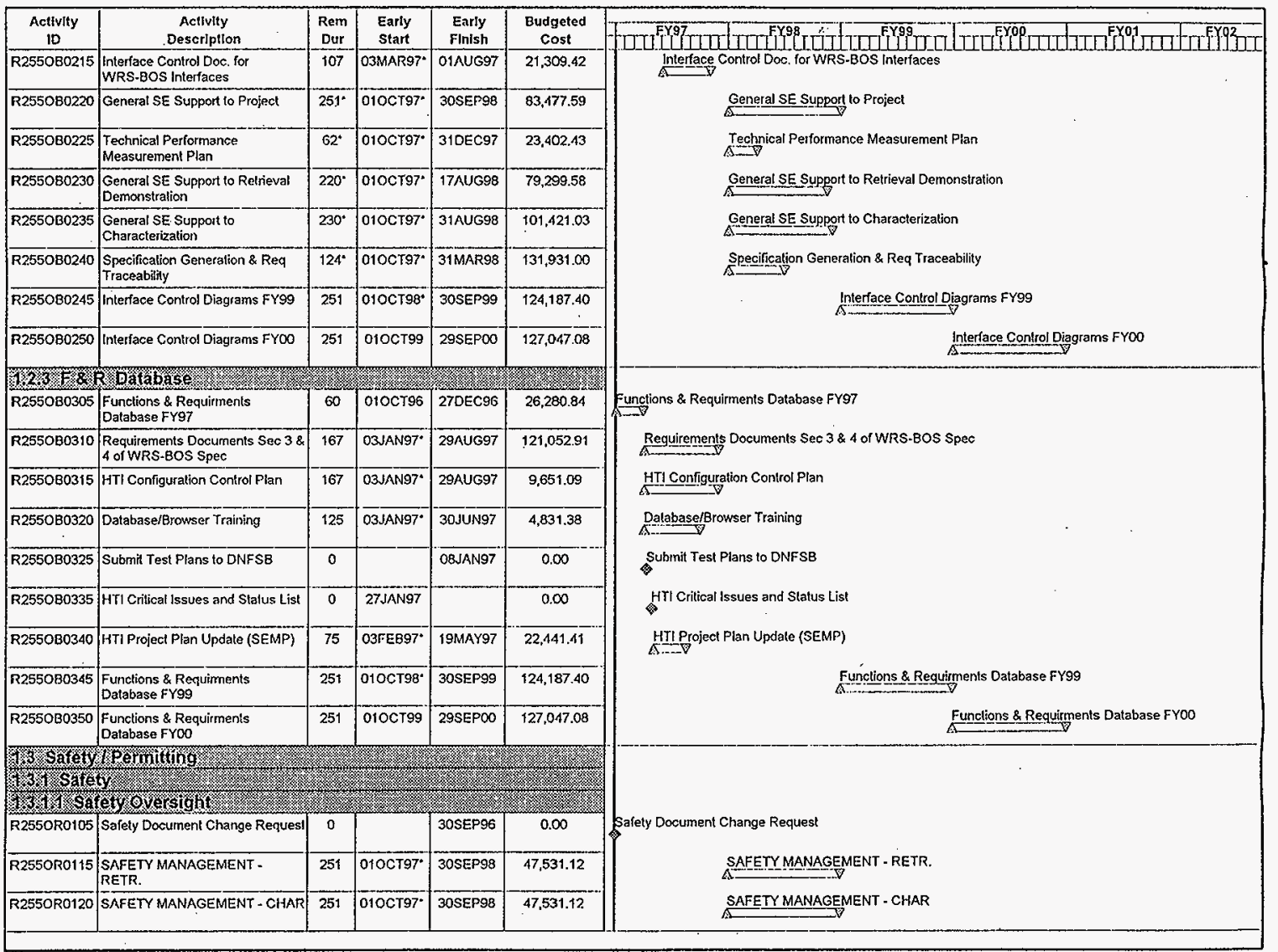




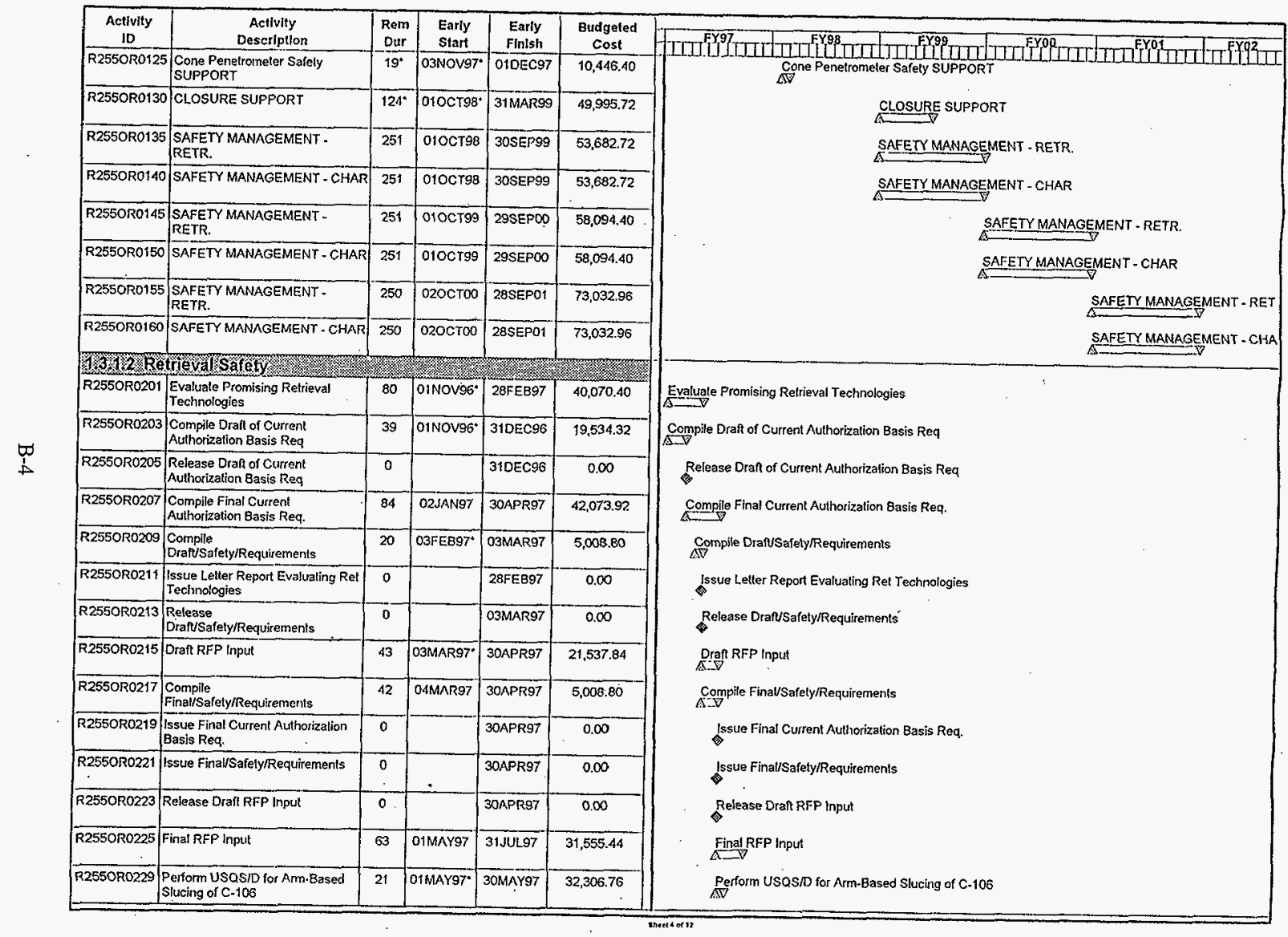




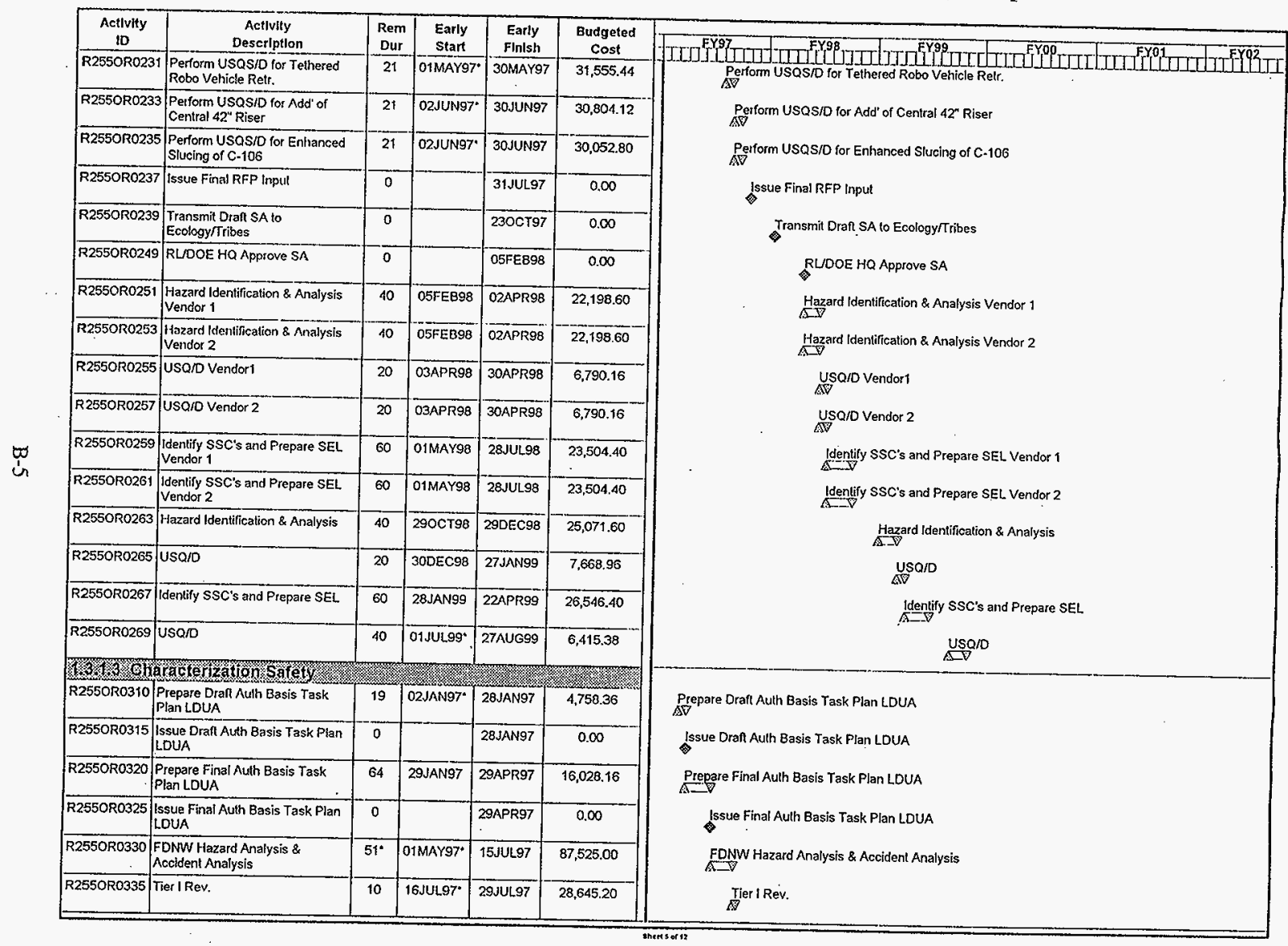




\begin{tabular}{|c|c|c|c|c|c|c|}
\hline $\begin{array}{l}\text { Actlulty } \\
\text { ID }\end{array}$ & $\begin{array}{l}\text { Acilvity } \\
\text { Description }\end{array}$ & $\begin{array}{l}\text { Rem } \\
\text { Dur }\end{array}$ & $\begin{array}{l}\text { Early } \\
\text { Start }\end{array}$ & $\begin{array}{l}\text { Early } \\
\text { Finish }\end{array}$ & $\begin{array}{l}\text { Budgefed } \\
\text { Cost }\end{array}$ & 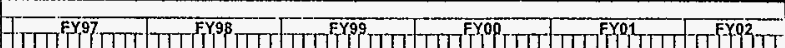 \\
\hline R255OR0340 & Tier Ill Rev. & 15 & 30.ง & I9AUG97 & $15,171.00$ & Tier lil Rev. \\
\hline R2.550R0345 & Tier \|Rev. & 15 & $30 \mathrm{JUL} .97^{*}$ & 19AUG97 & $15,171.00$ & 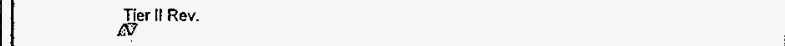 \\
\hline R255OR0350 & $\begin{array}{l}\text { Consolidated HTI Sarety Analysis } \\
\text { Repor Prep }\end{array}$ & 20 & 30 JUL.97 & $26 A \cup G 97$ & $20,035.20$ & $\begin{array}{l}\text { Consolidaled HTI Saféty Analysis Report Prep } \\
\text { P }\end{array}$ \\
\hline R2550R0355 & $\begin{array}{l}\text { Consolidated HTI Safety Analyis } \\
\text { Repoit }\end{array}$ & 0 & & 26AUG97 & 0.00 & Consolidated HTI Safely Analyis Report \\
\hline$\overline{R 2550 R 0360}$ & $\begin{array}{l}\text { Hazard ldenlification \& Analysis } \\
\text { Irs }\end{array}$ & 40 & 010ст97" & 25 NOV97 & $22,198.60$ & Hazard Identificalion \& Analysis ITS \\
\hline R255OR0365 & USQR ITS & 20 & 26 NOV97 & $290 \mathrm{DEC97}$ & $6,790.16$ & $\underset{\Delta V}{\text { USOIOIS }}$ \\
\hline R2550R0370 & $\begin{array}{l}\text { Identify SSC's and Prepare SEL } \\
\text { ITS }\end{array}$ & 60 & $300 E C 97$ & 25MARS8 & $23,504.40$ & 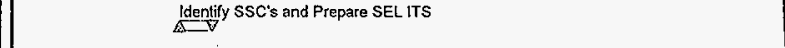 \\
\hline R2550R0375 & Deploy LDUA & 0 & O3FEB98 & & 0.00 & Deploy LDUA \\
\hline 1.3. & Miting & 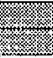 & 2 & 23 & $\sqrt[3]{20}$ & \\
\hline R2550P0105 & Permilting Plan for C-106/AX-104 & 123 & O10CT96A & 28MAR97 & $13,350,48$ & ermititing Plan for C-106/AX-104 \\
\hline $\overrightarrow{R 2550 P 0110}$ & $\begin{array}{l}\text { PERMITTING MANAGEMENT - } \\
\text { RETR. }\end{array}$ & 251 & $0100 T 97^{\circ}$ & 30SEP98 & $23,765.56$ & PERMITIING MANAGEMENT - RETR. \\
\hline R2550P0115 & $\begin{array}{l}\text { Cone Peneirometer Permitting } \\
\text { SUPPORT }\end{array}$ & $19^{*}$ & O3NOV97" & 010 EC97 & $3,594,36$ & $\begin{array}{l}\text { Cone Penetrometer Permitting SUPPORT } \\
\text { AV }\end{array}$ \\
\hline R2550P0120 & Permitting Plan Update & $62^{*}$ & O2JAN98. & $31 \mathrm{MAR} 98$ & $14,459.13$ & Permitting Plan Updale \\
\hline$R 2550 P 0125$ & $\begin{array}{l}\text { PERMITTING MANRGEMENT. } \\
\text { RETR. }\end{array}$ & 251 & $010 \mathrm{CT98}$ & 30SEP99 & $26,841,36$ & PERMITTING MANAGEMENT - RETR. \\
\hline R2550P0130 & Permitting Plan Update & $62^{\circ}$ & O4JAN99. & 31MAR99 & $14,798.62$ & Permilling Plan Update \\
\hline R2550P0135 & $\begin{array}{l}\text { PERMITTING MANAGEMENT . } \\
\text { RETR. }\end{array}$ & 251 & $010 \mathrm{cr99}$ & 29SEP00 & $29,047.20$ & PERMITTING MANAGEMENT - RETR. \\
\hline R255OP0140 & Permitting Plan Update & $63^{\circ}$ & OUJANOO & 31MAROO & $15,202.16$ & Permitting Plan Update \\
\hline R255OP0145 & $\begin{array}{l}\text { PERMITINING MANAGEMENT - } \\
\text { RETR. }\end{array}$ & 250 & $0200 T 00$ & 28SEP01 & $36,516.18$ & PERMITTING MANAGEMENT - \\
\hline R255OP0150 & $\begin{array}{l}\text { Start Maintaining Administrative } \\
\text { Record }\end{array}$ & $1^{*}$ & 13JUNOY & 13JUNO1 & 0.00 & Start Maintaining $\mathrm{A}$ \\
\hline 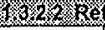 & Hevalempirting & & & & & \\
\hline R255OP0229 & $\begin{array}{l}\text { C-106 Retrieval NEPA } \\
\text { Supplement Anal }\end{array}$ & $178^{\circ}$ & 02JUN97" & 17FEB98 & $34,204.77$ & C-106 Retrieval NEPA Supplement Anal \\
\hline R255OP0281 & C-106 Heel Relsieval Air Permits & $299^{\circ}$ & O2FEB98 & O9APR99 & $43,646.75$ & 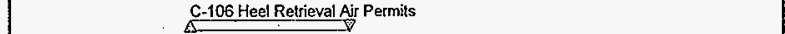 \\
\hline 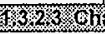 & 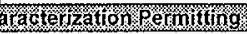 & 2 & 2 & 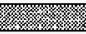 & 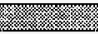 & \\
\hline
\end{tabular}




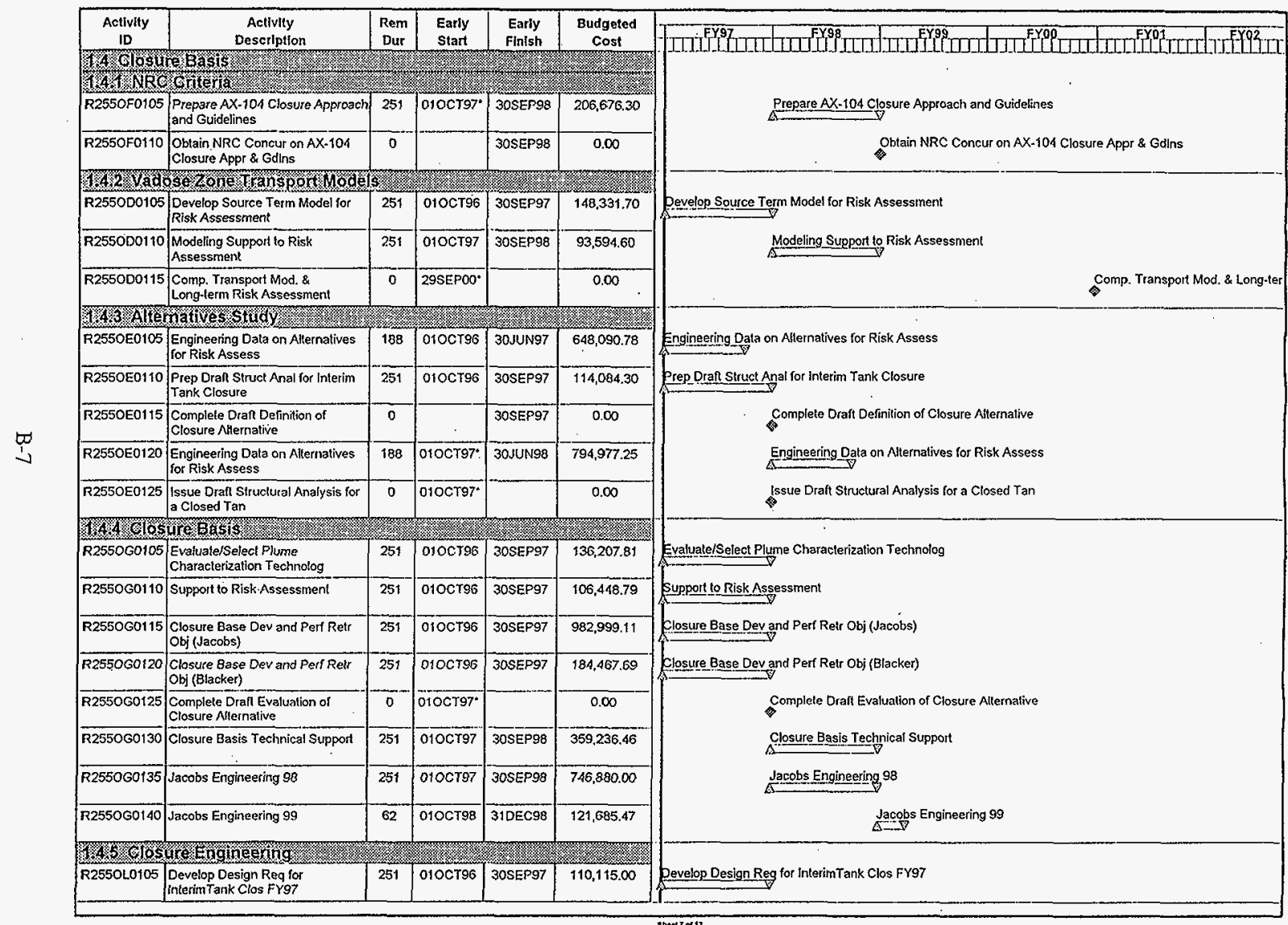




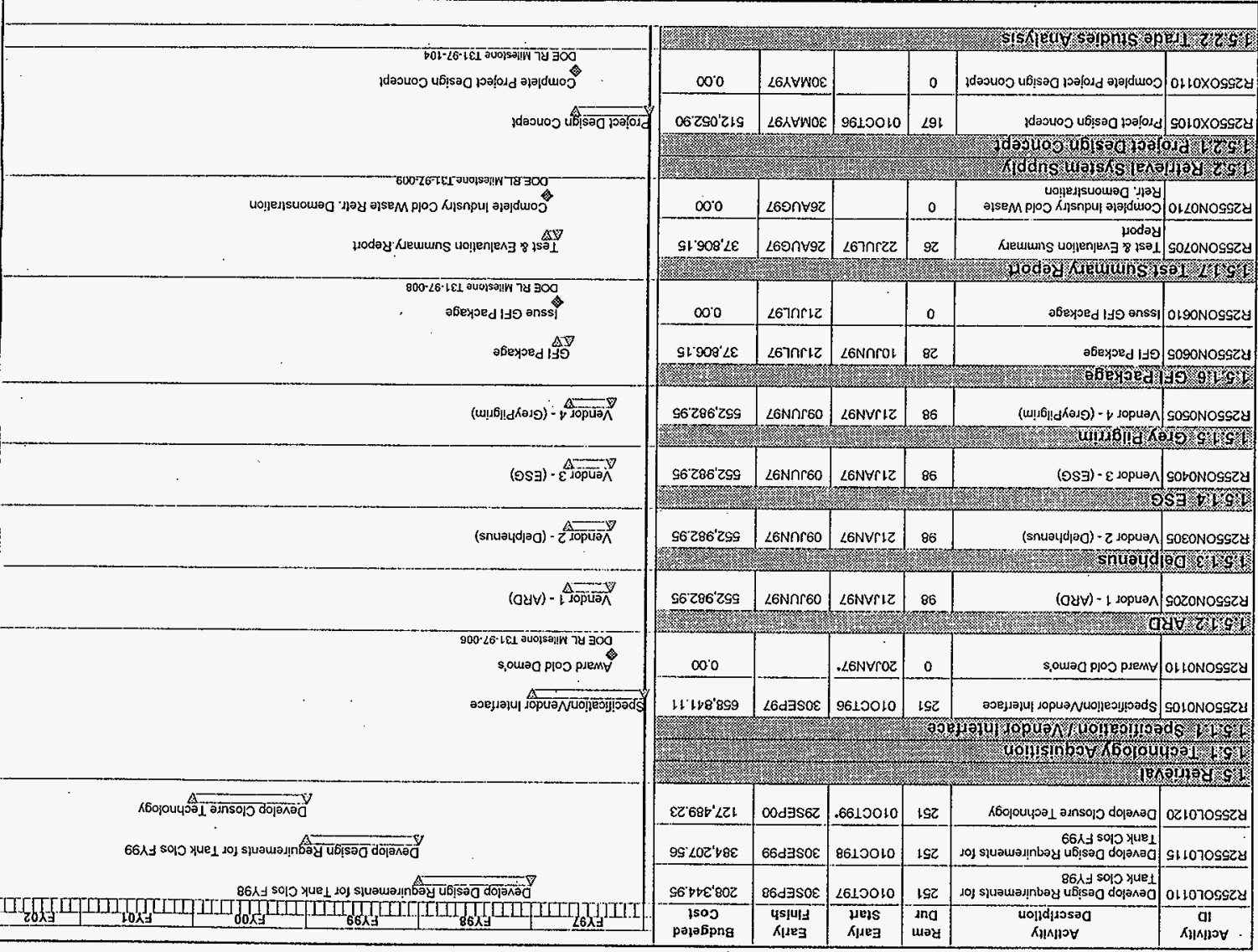




\begin{tabular}{|c|c|c|c|c|c|c|}
\hline $\begin{array}{l}\text { Activity } \\
\text { ID }\end{array}$ & $\begin{array}{c}\text { Activity } \\
\text { Description }\end{array}$ & $\begin{array}{c}\text { Rem } \\
\text { Dur }\end{array}$ & $\begin{array}{l}\text { Earty } \\
\text { Start } \\
\end{array}$ & $\begin{array}{l}\text { Early } \\
\text { Finish }\end{array}$ & $\begin{array}{l}\text { Budgeted } \\
\text { Cost }\end{array}$ & 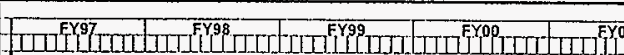 \\
\hline $\mathrm{R} 2550 \times 0205$ & Trade Studies Aralysis & 251 & 0100796 & 30SEP97 & $392,009,40$ & rade Studies Analysis \\
\hline \multicolumn{6}{|c|}{ 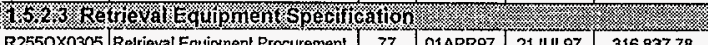 } & \multirow{3}{*}{$\begin{array}{c}\text { Retrieval Equipment Procurement Spec, } \\
\text { Issue C-106 Retrieval RFP } \\
\text { DOE RLMAitestore T31.97.105 }\end{array}$} \\
\hline $\mathrm{R} 2550 \times 0305$ & $\begin{array}{l}\text { Retrieval Equiphnent Procurement } \\
\text { Spec. }\end{array}$ & 77 & 01APR97 & 21.JUL.97 & $316,837,78$ & \\
\hline$R 2550 \times 0310$ & Issue C-10s Retrieval RFP & 0 & & OBAUG97 & 0.00 & \\
\hline \multicolumn{6}{|c|}{$52 \% 1 \%$ ad 8 Award $\mathrm{C} 106 \mathrm{Refrieval}$} & \multirow{3}{*}{$\begin{array}{l}\text { Bid \& Award C-106 Retreival } \\
\text { Contract Award }\end{array}$} \\
\hline R2550x0405 & Bid \& Award C-10G Retreival & 122 & 11AUG97 & O4FEB98 & $128,136.42$ & \\
\hline$R 2550 \times 0410$ & Contract Award & 0 & & 04FEB98 & 0.00 & \\
\hline \multicolumn{6}{|c|}{ 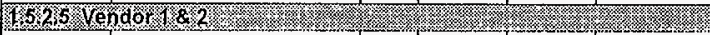 } & \multirow{4}{*}{ Vendor Contract Management \& Interface Coord } \\
\hline$R 2550 \times 0505$ & $\begin{array}{l}\text { Vendor Contract Management \& } \\
\text { Interface Coord }\end{array}$ & 218 & 17 NOV $97^{\circ}$ & 30SEPY 8 & $613,077,00$ & \\
\hline$R 2550 \times 0510$ & System Definition & 155 & 05FEB98 & 16SEP98 & $1,248.690 .00$ & \\
\hline $82550 \times 0515$ & System Definition & 155 & O5FEB98 & 16SEP98 & $1,248,690.00$ & \\
\hline \multicolumn{6}{|c|}{ 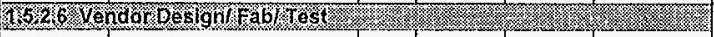 } & \multirow[b]{2}{*}{ Vendor Downselect } \\
\hline$R 2550 \times 0605$ & Vendor Downselect & 30 & 17SEP98 & $280 \mathrm{CT98}$ & 85.323 .34 & \\
\hline R2550X0610 & $\begin{array}{l}\text { Contract Management \& Site } \\
\text { Inlerface Coord }\end{array}$ & $225^{\circ}$ & $290 \mathrm{CT} 98$ & 22SEP99 & $645,272.01$ & Contraci Management \& Site Interface Coord \\
\hline $\mathrm{R} 2550 \times 0615$ & Make Vendor Selection & 0 & 290 CT98* $^{*}$ & & 0.00 & Make Vendor Selection \\
\hline$R 2550 \times 0620$ & $\begin{array}{l}\text { Vendor WRS Equipment } \\
\text { Design/Fabricalion }\end{array}$ & 195 & 290 CT98. & 10AUG99 & $3,195,020.00$ & 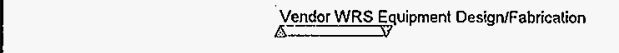 \\
\hline $\mathrm{R} 2550 \times 0630$ & On-site Contract Management & 166 & 23SEP99 & 19MAYOO & $293,835.99$ & On-site Contracl Management \\
\hline$R 2550 \times 0635$ & Vendor On-site Testing & $111^{*}$ & 235EP99 & OBMAROO & 925.033 .14 & 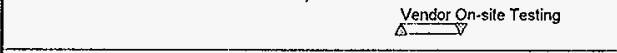 \\
\hline \multicolumn{6}{|c|}{ H\$120 Wondor 6} & \multirow[b]{2}{*}{ Retrieval Contingency } \\
\hline R2550X0705 & Retrieval Contingency & 245 & 010 TT99 & 21SEPOO & $6,318,895,50$ & \\
\hline \multicolumn{6}{|c|}{ 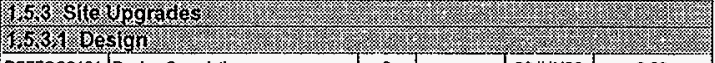 } & \multirow[b]{2}{*}{$\begin{array}{l}\text { Design Completion } \\
\text { DOE RL Milestone T31.98.010 }\end{array}$} \\
\hline R2550S0101 & Design Complelion & 0 & & 3OJUNS9 & 0.00 & \\
\hline \multicolumn{6}{|c|}{ 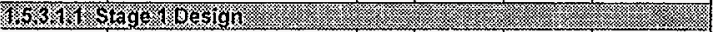 } & \multirow[b]{2}{*}{ SITE UPGRADENENDOR ICWG } \\
\hline R2550s0105 & SITE UPGRADENENDOR ICWG & $254^{*}$ & $010 \mathrm{cTs} 7^{*}$ & 30SEP98 & $597,996.78$ & \\
\hline
\end{tabular}




\begin{tabular}{|c|c|c|c|c|c|c|}
\hline $\begin{array}{c}\text { Actlvity } \\
\text { ID }\end{array}$ & $\begin{array}{c}\text { Actlvity } \\
\text { Description }\end{array}$ & $\begin{array}{l}\text { Rem } \\
\text { Dur } \\
\end{array}$ & $\begin{array}{l}\text { Early } \\
\text { Start }\end{array}$ & $\begin{array}{l}\text { Early } \\
\text { Finish } \\
\end{array}$ & $\begin{array}{l}\text { Budgeted } \\
\text { Cost }\end{array}$ & \multirow{3}{*}{ 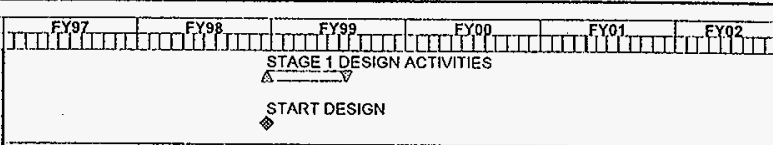 } \\
\hline $\mathrm{R} 2550 \mathrm{~S} 0110$ & STAGE 1 DESIGN ACTIVITIES & $150^{\circ}$ & 17 SEPS8 & 22APR99 & $1.106,411.59$ & \\
\hline R2550S0115 & START DESIGN & 0 & 17 SEP98 & & 0.00 & \\
\hline \multicolumn{2}{|c|}{ 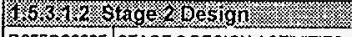 } & & 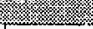 & 8 & 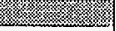 & \multirow[b]{2}{*}{ STAGE 2 DESIGN ACTMITIES } \\
\hline R2550S0205 & STAGE 2 DESIGN ACTIVITIES & $130^{\circ}$ & $280 E C 98$ & 30JUN99 & $1,349,386.14$ & \\
\hline \multicolumn{3}{|c|}{ 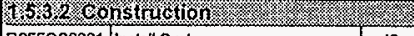 } & & 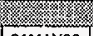 & 2 & \multirow[b]{2}{*}{$\underset{\&-1}{\text { Instal System }}$} \\
\hline R2550S0301 & Install System & 42 & OBMARO0 & OIMAYOO & 906.444 .11 & \\
\hline \multicolumn{2}{|c|}{ 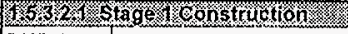 } & & 2 & 28 & 2 & \multirow[b]{2}{*}{ STAGE 1 CONSTRUCTION } \\
\hline $\mathrm{R} 255050305$ & STAGE 1 CONSTRUCTION & $206^{\circ}$ & 23APR99 & 17FEBOO & $3,417,602.13$ & \\
\hline R255050309 & START CONSTRUCTION & 0 & & 20MAY99 & 0.00 & SIART CONSTRUCTION \\
\hline \multicolumn{3}{|c|}{ 453222stage 2construction } & & & 2 & \multirow{4}{*}{$\begin{array}{l}\text { SLUCING COMPLETE } \\
\text { START STAGE } 2 \text { CONSTRUCTION } \\
\text { STAGE 2 CONSTRUCTION }\end{array}$} \\
\hline R2550S0401 & SLUCING COMPLETE & 0 & 30JUN99. & & 0.00 & \\
\hline$R 255050402$ & $\begin{array}{l}\text { START STAGE } 2 \\
\text { CONSTRUCTION }\end{array}$ & 0 & 30JUN99 & & 0.00 & \\
\hline$R 255050403$ & STAGE 2 CONSTRUCTION & $289^{\circ}$ & 30.JUN99 & 23 AUGO0 & $4,896,064,47$ & \\
\hline R2550S0462 & COMPLETE ATPS/OTPS & 0 & & 22SEPOO & 0.00 & COMPLETE ATPS/OTPS \\
\hline$R 255050464$ & $\begin{array}{l}\text { TURNONER TO OPS FOR } \\
\text { SLUICING }\end{array}$ & 0 & & $200 C T 00$ & 0.00 & TURNOVER TO OPS FOR SL \\
\hline \multirow{2}{*}{\multicolumn{6}{|c|}{ 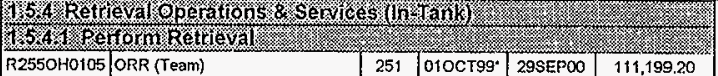 }} & \multirow[b]{2}{*}{ ORR (Team) } \\
\hline & ORR (Team) & 251 & о10ст99. & 29SEFOO & $111,199.20$ & \\
\hline R255OHO110 & C-106 Retrieval Testing & $173^{\circ}$ & OZMAYOO & TOJANO1 & $321,244.70$ & C-106 Retrieval Testing \\
\hline $\mathrm{R} 255 \mathrm{OH} 0120$ & ATPIOTPIORR (Prep) & 79 & O2MAYOO & 23AUGOO & $868,763.40$ & ATPIOTPIORR (Prep) \\
\hline $\mathrm{R} 255 \mathrm{OHO140}$ & Approval to slart (CD) & 0 & & 23AUGOO & 0.00 & Approval to start (CD) \\
\hline R255OH0145 & Perform Retrieval & 80 & 2AAUGOO & 18DECOO & $1,213,409,92$ & $\stackrel{\text { Perform Retrieval }}{\square}$ \\
\hline R255OH0150 & Retrieval Contract Management & 250 & $020 c r 00^{\circ}$ & 28SEPO1 & $367,547.80$ & Retrieval Contract Management \\
\hline \multicolumn{6}{|c|}{15442,0 pmobilize } & \multirow[b]{2}{*}{ Demobilize Retrieval System } \\
\hline R255OHO205 & Demobilize Retrieval System & 10 & 190ECOO & 15FEBO1 & $\$ 28,555,61$ & \\
\hline \multicolumn{6}{|c|}{ 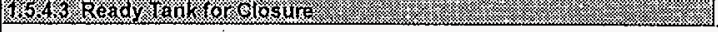 } & . \\
\hline
\end{tabular}




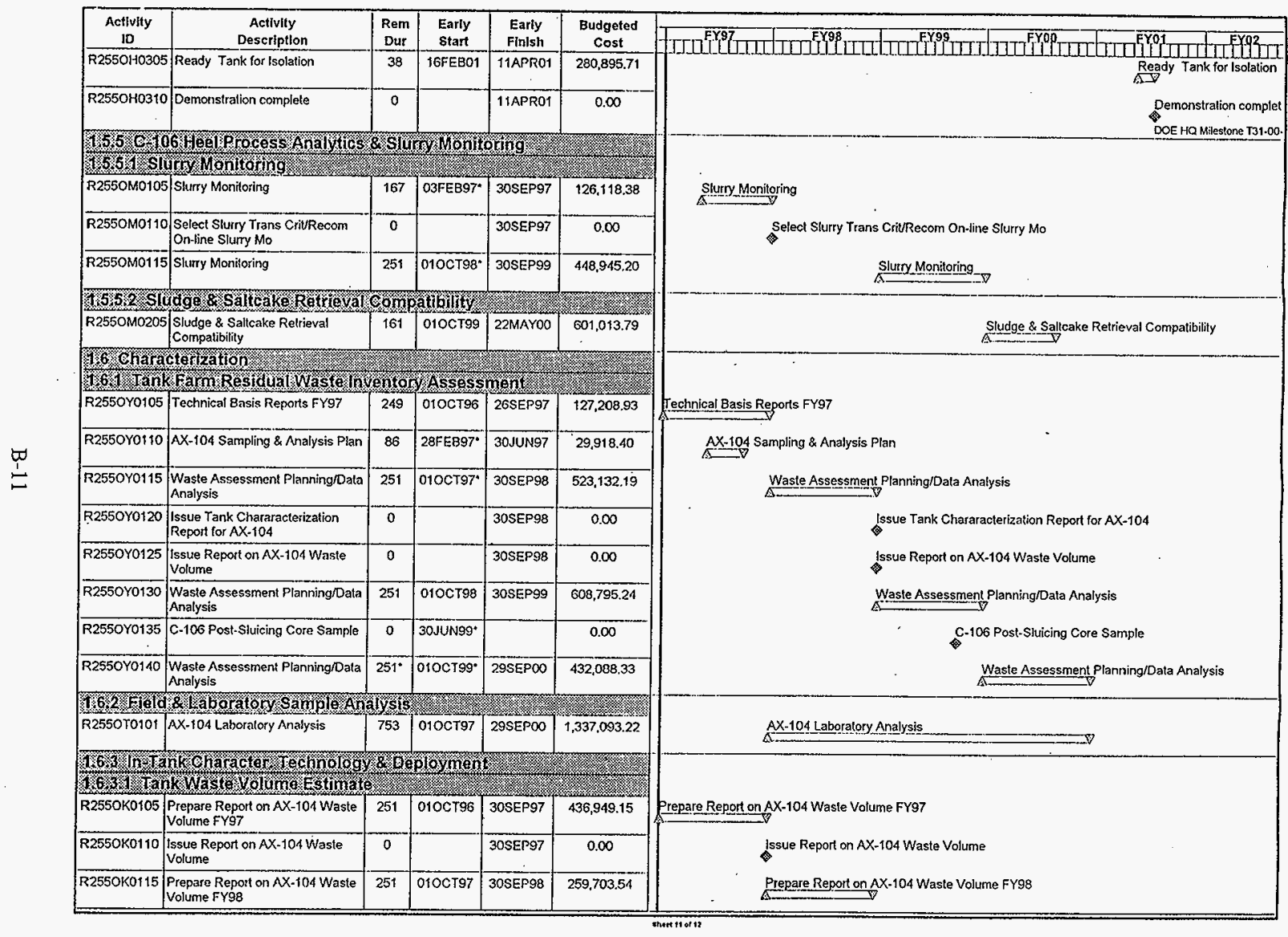




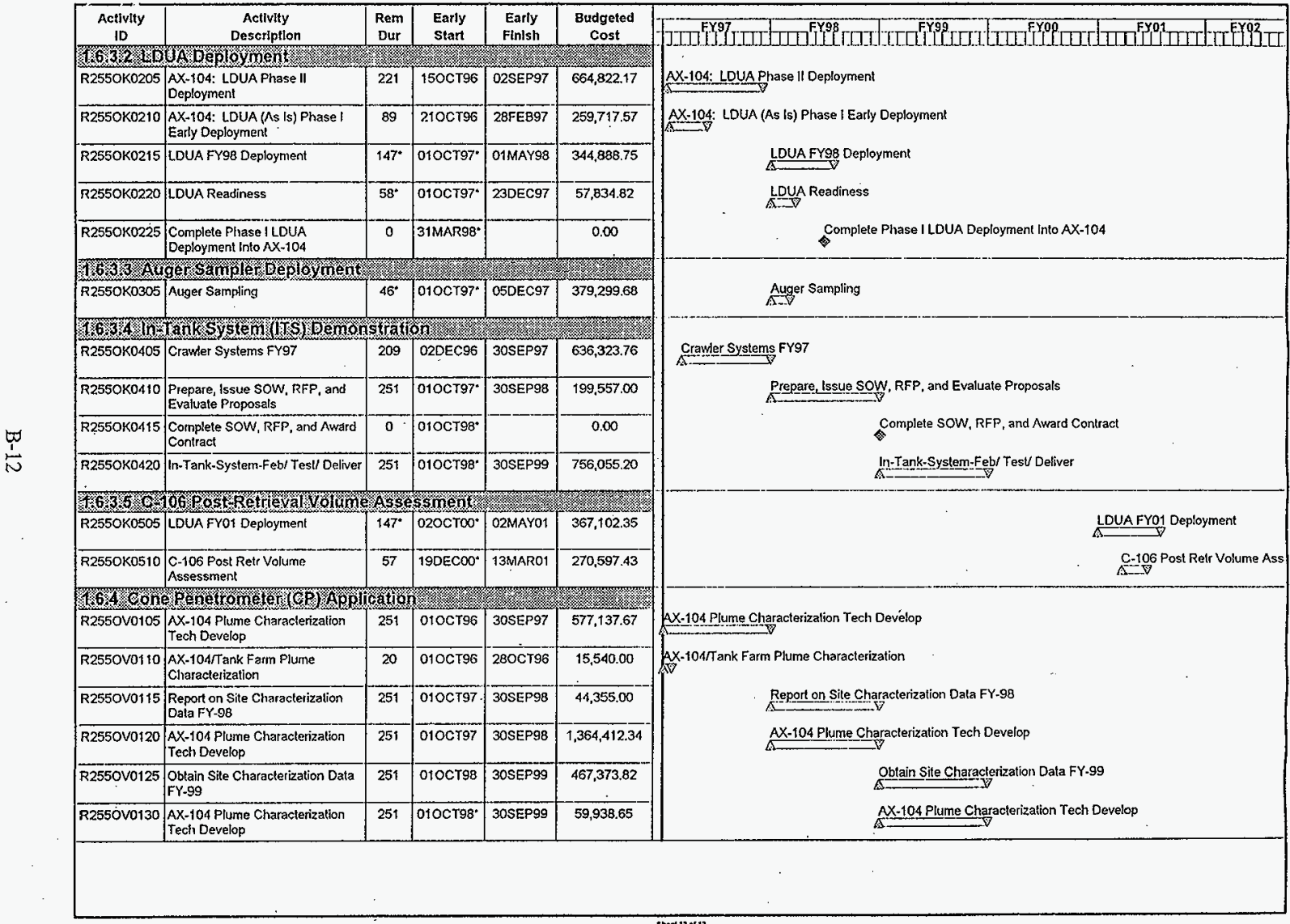


HNF-SD-WM-PMP-022, Rev. 0

\section{APPENDIX C}

RELEVANT ACTIVITIES AT HANFORD AND OTHER SITES OF THE U.S. DEPARTMENT OF ENERGY NUCLEAR WEAPONS COMPLEX 
HNF-SD-WM-PMP-022, Rev. 0

This page intentionally left blank.

C-ii 


\section{C.0 INTRODUCTION}

Activities of the HTI must be effectively integrated with related activities at the Hanford Site and other DOE sites to maximize their impacts both locally and across the DOE complex. Furthermore, the cross-dissemination of knowledge obtained from such activities is essential if benefit/cost ratios are to be maximized.

There are several ongoing activities at the Hanford Site with which the HTI must be integrated; the (1) W-320 waste retrieval project, (2) waste characterization program, (3) tank farm operations and maintenance, and (4) waste tank safety. Summaries of the relevant activities are presented in Section C. 1 .

Relevant waste retrieval and tank closure activities at ORNL, SRS, INEL, WVNS, and Fernald, when integrated with the HTI Project scope, will provide a national perspective on: (1) key technologies for tank waste retrieval, (2) cost data for retrieval, (3) closure issues, processes and criteria, and (4) tank closure costs. To ensure integration of the HTI activities with related DOE retrieval and tank closure activities, data inputs from the other activities are accounted for in the HTI Project schedule; HTI Project staff are participating in national workshops; and TFA staff who provide technical assistance at the other DOE sites are participating in HTI Project planning. Descriptions of key tank waste retrieval and closure activities at other sites and their principal interfaces with the HTI are provided in Section C.2.

\section{C.1 INTERFACES WITH HANFORD SITE BASELINES, PROGRAMS, AND PROJECTS}

Hanford Site elements of the DOE Office of Environmental Restoration and Waste Management (EM-30) that support the HTI consist of the following activity data sheet (ADS) numbers:

- ADS 1210-0 (Waste Retrieval Project)

- ADS 1130-0 (Waste Characterization Program)

- ADS 1100 (Tank Farm Operations and Maintenance)

- ADS 1110-0 (Waste Tank Safety).

\section{C.1.1 Waste Retrieval Project}

The activities in ADS 1210 (Waste Retrieval Program) are the foundation of the HTI and consist of the ACTR program, tank 241-C-106 sludge removal (Project W-320), and closure-readiness activities. Related activities include the Initial Single Shell Tank Retrieval System (ISSTRS) and associated. Leak Detection Monitoring and Mitigation (LDMM). 
C.1.1.1 Acquire Commercial Technology for Retrieval (ACTR) Program. The ACTR program will obtain a determination from industry of the best commercial approaches for retrieving waste from Hanford Site tanks. A full range of components, systems, concepts, and acquisition approaches are being considered. ACTR Program goals are to reduce retrieval cost and risk, verify estimates of performance and cost, develop cost and timeefficient technology acquisition paths, help the Hanford Site to understand industry's approaches, and help industry to understand Hanford Site constraints.

C.1.1.2 Tank 241-C-106 Soft Sludge Removal, Project W-320 will precede the HTI Project in tank 241-C-106. Project W-320 will remove the soft sludges on top of the hard-heel waste by hydraulic sluicing. At the completion of Project W-320, tank 241-C-106 will be made ready for the HTI Project to remove the heel.

C.1.1.3 Closure-Readiness Activities. Closure-readiness activities other than those specific to tank 241-AX-104 which are part of the HTI Project include tank farm closure engineering trade studies and bi-annual updating of the SST closure work plan. The closure work plan identifies regulatory criteria applicable to closure alternatives. The engineering trade studies will evaluate closure alternatives, establish closure performance requirements, assess relative performance of closure alternatives, and evaluate their compliance with regulatory criteria. These activities will include the application of numerical methods to simulate closure system performance and allocate performance requirements to components of the closure system.

C.1.1.4 Initial Single-Shell Tank Retrieval System. The ISSTRS will provide the initial retrieval system for a SST farm at the Hanford Site. Salt cake and sludge retrieval will be demonstrated. Conceptual design is scheduled to be complete by April 1997. Detailed design will be completed in 1998. Retrieval of the first tank will begin in 2003 . For the Hanford Site, past-practice sluicing is the reference retrieval technology where tank leakage is not known to have occurred.

C.1.1.5 Leak Detection Monitoring and Mitigation Ongoing LDMM efforts at the Hanford Site will incorporate findings from recent functions and requirements determination, LDMM technology surveys, a study of potential retrieval operations responses to leakage, an LDMM technology trade study, and a summary of LDMM strategy. Criteria for determining maximum potential leakage from sluicing, and allowable leakage from retrieval operations are being prepared to support Milestone M45-08-T02 (April 1997). The criteria and strategy for LDMM will apply a risk-based decision process, in the context of previous LDMM findings, to determine maximum anticipated and allowable leakage limits within which SST waste sluicing can proceed. In a separate but related effort, Electro-Resistance Tomography (ERT), deployed using the cone penetrometer technique, is being evaluated for use as a SST leak monitoring and detection method. 


\section{C.1.2 Waste Characterization Project}

Activities in ADS 1130-0 (Waste Characterization Project) that support the HTI consist of decisions and information or data pertaining to tank wastes that are being identified, acquired, and documented using the data quality objectives assessment process. Sampling, analysis, and documentation of the characterization of residual waste in tank 241-C-106 following sluicing by Project W-320 will be provided by the waste characterization project. The data evaluation task will develop a comprehensive tank waste inventory using all available data sources (historic, as well as current). Tasks to upgrade laboratory facilities include renovation of the 222-S Laboratory and updating of existing analytical facilities to meet the requirements of Hanford Site information systems management. New equipment, instruments, and procedures for routine use in laboratory hot cells will be required.

The workscope includes enhancing cost effectiveness, identifying new equipment needs and improving sampling and analytical processes.

\section{C.1.3 Tank Farm Operations and Maintenance}

Activities in ADS 1100-0 (Tank Farm Operations and Maintenance) that support the HTI include routine tank farms surveillance and facility operations, including conduct of operations and maintenance, operator training, and compliance with environmental and occupational safety regulations.

\section{C.1.4 Waste Tank Safety}

Activities in ADS 1110-0 (Waste Tank Safety) that support the HTI are the resolution of safety issues (e.g., criticality, flammable gas) and issuance of safety documentation. Appendix E provides the strategy for safety program implementation for the HTI Project.

\section{C.2 WASTE RETRIEVAL AND TANK CLOSURE ACTIVITIES AT OTHER WEAPONS COMPLEX SITES}

Complex-wide waste retrieval activities include the recovery of salt cake and/or sludgeheel wastes in gunite tanks at the ORNL site and large, steel-lined tanks at SRS and West Valley Nuclear Services. Fernald will sluice a soil-like waste from its silos. Retrieval of sludges at ORNL and INEEL from horizontal steel tanks is also planned. A wide range of waste retrieval characterization and conveyance technologies will be deployed in these retrieval projects, yielding critical performance and cost data. These data will be shared among the sites, facilitated by the Tanks Focus Area (TFA). Complex-wide facility closure activities involve the CERCLA and RCRA processes, and closure under state waste-water permits. Although these processes may differ from those being implemented at the Hanford Site to close SSTs and DSTs, lessons learned from the processes of obtaining regulator and stakeholder involvement will be shared among the sites. It is expected that information derived from the closure activities at other sites will accelerate the closure-definition process 
that is part of the scope of the HTI.

Listed below are summaries of complex-wide retrieval and closure activities, and their relationships to the HTI Project. Included in the summaries are technologies and processes (developed, deployed, and emerging) that could potentially be applied to the HTI or being considered by HTI that could be applicable elsewhere.

\section{C.2.1 Oak Ridge National Laboratory}

Retrieval activities at ORNL include vertical tanks made of gunite and cylindrical, horizontal steel tanks. The Gunite and Associated Tanks (GAAT) and the Old HydroFracture (OHF) Tanks will be closed under the CERCLA process. Other tanks farms such as the Bethel Valley Evaporator Storage Tanks (BVEST) and the Melton Valley Storage Tanks (MVST) are currently in service and have waste retrieval and transfer operations planned for continued operations until waste storage is no longer required. Descriptions of the retrieval and closure activities, and their potential interfaces with the HTI are discussed below.

C.2.1.1 Gunite and Associated Tanks (GAAT). Eighteen tanks containing LLW and considered to pose the highest risks were assigned to Waste Area Grouping 1 Operable Unit, GAAT. The GAAT are being closed under the CERCLA remedial action process. This process includes remedial investigations and feasibility studies leading to a record of decision. These tanks were retrieved by sluicing in the 1980's. Residual waste includes liquid, sludge and solid chunks. The GAAT waste retrieval effort will provide cost data useful to the HTI. The CERCLA closure process may yield important insights into the RCRA closure process for the HTI.

\section{C.2.1.2 Gunite and Associated Tanks: GAAT Treatability Study. The GAAT} Treatability Study is an exhibition of retrieval, pretreatment, and stabilization processes for the gunite tanks located in both the north and south tank farms at ORNL. This work is a cooperative effort between EM-40 and EM-50, and is taking place in tanks W-3 and W-4, the primary tanks in the north tank farm. Treatability studies will test a 7,000 psi confined sluicer with jet-pump waste conveyance deployed by a robotic arm (a Modified LDUA) and by a remotely-controlled vehicle (a RedZone Robotics Houdini Vehicle). CERCLA treatability studies will also use the LDUA for tank residual waste heel characterization. The purpose of tank heel characterization will be to determine which sludges can be removed and treated with presently available technology and equipment, and which sludges will require further development of waste removal equipment and treatment facilities.

Sampling is complete. Infrastructure setup for GAAT retrieval began in July 1996. In the second quarter of FY 1997, a confined-sluicing tool developed by the TFA will be deployed by Houdini, a remotely-operated vehicle developed by RedZone and the Morgantown Energy Technology Center. In June 1997, the Modified LDUA will be installed to deploy the confined-sluicing tool. Both systems are expected to be used to remove waste from the south farm. Retrieved waste will be used to test pretreatment and immobilization processes. The treatability study will be complete in FY 1997. 
C.2.1.3 Gunite and Associated Tanks: South Tank Farm. The processes tested in GAAT W-3 and W-4 will be used to remove waste from tanks in the south farm starting in FY 1998. Closure will commence in FY 2000.

\section{C.2.1.3 Inactive Waste Storage Closure Project. In the Oak Ridge Federal Facility} Agreement (Tennessee et al. 1992), the liquid low-level waste (LLLW) tanks that were not assigned to the GAAT Operable Unit were assigned to one of five batches (I through V). A streamlined CERCLA process is being applied to these 37 tanks. Remedial actions for Batch I tanks began in FY 1995. All tanks in Batch I have been emptied.

C.2.1.4 Melton Valley Storage Tanks (MVST) Retrieval. The MVSTs are horizontallyconfigured underground tanks located at ORNL. Approximately $1,500 \mathrm{~m}^{3}(400,000 \mathrm{gal})$ of high-activity supernate stored in these tanks will be retrieved and solidified to ensure that storage space is available for newly-generated waste. ORNL must retrieve and solidify Melton Valley supernate on a regular ( 2 to 3 years) basis. These waste tanks contain varying amounts of bottom sludge with varying consistencies. The sludge occupies about one-half of the tank volumes and contains appreciable concentrations of transuranic elements. A detailed chemical analysis has been completed on this material and the distributions of the sludge layers have been mapped. These are active tanks; the volumes and distributions of sludge changes as materials are transferred between tanks. Plans for retrieval of the sludges are being formulated. Data from complex-wide retrieval campaigns, such as for the HTI, will provide useful process and technology information for the MVST retrieval operations.

\section{C.2.1.5 Waste Area Group, Old Hydro-fracture (OHF) Tanks Area, Contents Removal} (EM-40). Five Hydro-fracture tanks (T-1, T-2, T-3, T-4, and T-9) contain a total of $30,000 \mathrm{Ci}$ of radioactive material at this location. The sizes of the tanks vary from 50 to $95 \mathrm{~m}^{3}(13,000$ to $25,000 \mathrm{gal})$, and all tanks contain fission products and actinides. The scope of this CERCLA interim action is to sluice each tank and to pump the slurry to MVST. Once most of the sludge has been removed from the tanks, further investigation will determine the long-term risk from residual waste left after sluicing. Retrieval and closure data from the HTI and from other ORNL tanks will provide additional insights into the closure process for this group of tanks.

C.2.1.6 Bethel Valley Evaporator Storage Tanks (BVEST), Contents Removal. The BVEST consist of three 50-ft-long horizontal tanks used to collect evaporator bottoms from the Bethel Valley Evaporators. The current need is to retrieve the TRU contaminated sludge so that subsequent waste steams will not have to be handled as TRU. Mobilization testing will be conducted in FY 1998 with transfer to MVST in the 99,00 time frame. Sludge mobilization and slurrying for transfer is the area this most directly relates to HTI.

\section{C.2.2 Idaho National Environmental Engineering Laboratory}

Near-term retrieval activities at INEEL include the V-9 and remaining V Tanks closure. Cease use of the HLW tanks, vertical, stainless steel-lined tanks, is not scheduled until the mid 2000's. 
C.2.2.1 V Tanks Closure. The $V$ tanks consist of several horizontal tanks and a few small tanks of vertical construction. They contain high levels of radionuclide contamination in conjunction with volatile organic chemicals, heavy metals, and polychlorinated biphenyls and are part of a CERCLA site. Cleanup of the $\mathrm{V}$ tanks is expected to be completed by FY 2000. To provide information supporting closure of the tanks, the tank waste will be sampled and characterized in FY 1996/97. Risk assessments based on the sample will be completed in FY 1997. The record of decision is scheduled to be issued in FY 1998, with remediation activities commencing thereafter. This activity forms a direct parallel to the HTI work to establish a process for determining retrieval and closure objectives for Hanford tanks.

C.2.2.2 Tank V-9 Closure. A tank stabilization and closure demonstration is being conducted by EM-40 and EM-50 (Subsurface Contamination Focus Area) on tank V-9 at INEL. Tank V-9 is a small vertical tank containing aqueous liquid and unconsolidated sediment. Its purpose was filtration through a bed of sand. Sampling found no sand in the tank. The aqueous liquid has been sampled. Pending the results of its analysis, some of the liquid may be removed and processed. The sediment will also be sampled and characterized. Several cement grouts will be evaluated for use in contaminant stabilization. Cold and then hot grouting tests will be done in a laboratory. The grout selected will be injected into the tank to immobilize the remaining liquids and solids. The process lines will then be capped to isolate the tank. The locations of underground pipes will be mapped.

The field test of in situ grouting will be completed by spring of 1998 and monitoring of the results will be conducted thereafter. The INEEL tank closure activities, particularly the use of engineered materials to stabilize the tank after retrieval, will provide data useful to the HTI in proposing tank stabilization methods.

\section{C.2.3 Savannah River Site}

Retrieval activities at the SRS include several waste retrieval tests to expedite retrieval of salt cake and hard-heel waste and close cleaned-out tanks.

C.2.3.1 Tank 20F Closure. Tank 20F is a Type IV (24.4-m [80-ft] dia.) tank with a heel consisting of about an inch of soft sludge. The TFA has provided assistance with evaluation of reducing grout for final stabilization of the residual sludge. As a first step, SRS

negotiated a land use plan for the Site with the State. SRS will remain an undeveloped park outside of the existing facilities. The point of compliance for the tanks was chosen to be the water table seep line and the measure of compliance was selected as Clean Water and Aquatic Life Standards. With these performance measures clearly established, SRS has completed a performance evaluation and negotiated a recipe for Class " $\mathrm{C}$ " mixture of grout with the residual sludge. On the 24th of April, 1997 SRS commences sequential grout pours through seven openings in the tank top. These pours divided and partially mixed with the sludge, leaving unmixed sludge and water on the surface of the grout. Dry grout was sprayed onto the surface to further mix with the sludge. This is followed by a second lift of wet grout to cap the waste system. The bulk of the tank will be filled with a Concrete Low 
Strength Material (fly ash and cement) with a high-strength intrusion cap on top. Closure is scheduled to be complete by July 1997 . This the first million gallon tank to be closed in the DOE Complex.

C.2.3.2 Tank 17F. Tank 20F is a Type IV (24.4-m [80-ft] diameter) tank with a heel consisting of about an inch of soft sludge. The TFA is assisting the Site in the development and deployment of the retrieval system. The a large portion of the sludge had to be removed to satisfy the performance evaluation. An air operated positive displacement pump was mounted at the apex of a metal " $\mathrm{V}$ ". A "water brush" sluicer pushed the sludge into the "V" and up to the pump. The pump moved the material over the ground through double hoses to Tank 18F. When the compliance level of retrieval is reached, Grout pour will commence in the same manner as for Tank 20F. Closure is scheduled to be complete by July 1997.

C.2.3.1 Tanks 18F and 19F Retrieval. Tanks $18 \mathrm{~F}$ and $19 \mathrm{~F}$ are Type IV (24.4-m [80-ft] diameter) tanks. Tank $19 \mathrm{~F}$ has a heel consisting of up to $12 \mathrm{in.}$ of salt, sludge, and cesiumladen zeolite. Tank $18 \mathrm{~F}$, when retrieved will contain all retrieved sludge form the F Tank Farm. The TFA will assist SRS in the retrieval of these tanks in FY 1998. Tank 19F will receive the Tank $17 \mathrm{~F}$ retrieval system for demonstration on this more challenging waste form. A more aggressive commercial system is being considered for final retrieval of Tank $19 \mathrm{~F}$, if needed, and for Tank 18F. The waste from Tank $18 \mathrm{~F}$ will be piped to a nearby sludge tank. Data from this waste heel removal activity will be particularly relevant to the HTI; detailed integration of HTI with this retrieval is therefore planned.

C.2.3.3 Tank 25/41 Salt Removal. The SRS has been seeking waste retrieval methods that are more cost effective than the use of mixer pumps. The TFA is assisting in development of a basis for selecting salt removal technology for future waste retrieval, based on the most cost-effective method that complies with chemistry-control requirements and production schedule constraints.

A sluicer may be used to clean the tank's upper structure and dissolve salt and a fluidic transfer pump with no moving parts will be used to transfer the brine into the their In-Tank Precipitation process for pretreatment for immobilization. This will be installed in FY 1998 and operated in FY 1999.

The salt removal will provide information useful to the broader SST waste retrieval issues at the Hanford Site. Specifically, the performance data from this will aid in selecting retrieval technology for salt cake in tanks at the Hanford Site.

\section{C.2.4 West Valley Nuclear Site}

In May 1988, pretreatment of waste at the West Valley Demonstration Plant was initiated. Pretreatment and sludge washing were completed in 1994. Operation of the waste vitrification facility will begin in FY 1996 and waste vitrification will be completed by the end of 1998. 
Two underground carbon-steel tanks at West Valley contain alkaline wastes and zeolitic cesium-extraction material. The zeolite from one of the tanks is being moved to the another waste tank where it will be combined with sludge waste and incorporated into the feed for HLW vitrification. Mixer pumps and confined-sluicing technologies will be used to retrieve the tank waste. West Valley has not issued an official strategy or schedule for site closure. Several alternatives are being considered, including the following:

- Removal of all structures and offsite disposal of all waste

- Indefinite onsite storage of some waste

- Disassembly and entombing of process buildings and back filling of the HLW tank farm with low-density concrete. The EIS ROD currently in preparation will identify the preferred alternative.

The HTI and other site retrieval and closure initiatives are expected to provide relevant information for retrieval and closure of the two West Valley storage tanks. The HTI will also benefit from the closure plans and decisions made there.

\section{C.2.5 Fernald}

Three abovegrade silos are used to store waste at Fernald, each with a capacity of $\sim 7,570,000 \mathrm{~L}$ ( $2 \mathrm{Mgal}$ ). Waste from Silo 1 was scheduled be removed using hydraulic mining equipment during a pilot-scale retrieval scheduled for FY 1997. An mishap during cold-melter testing has resulted in a rebaselining effort to replan the strategy. A Houdini robot was developed for deployment in FY 2000 to retrieve discrete objects that cannot be sluiced, remove the hard-heel waste, and decontaminate the tank interior. Full-scale retrieval of the Fernald tank wastes was planned to be initiated in FY 1999 or FY 2000. Following removal of the tank waste residues, the concrete silos will be demolished, the rubble processed for size reduction, and permanently stored in the Fernald onsite disposal facility. Fernald waste retrieval and silo closure activities are expected to provide retrieval and closure performance data useful to the HTI.

\section{C.2.6 Summary}

Tables C-1 and C-2 summarize activities and technologies at other sites which will provide information which is expected to be useful to the HTI Project and which, in turn, can make use of information generated by the HTI Project. 
Table C-1. Complex-Wide Retrieval and Closure Activities.

\begin{tabular}{|c|c|c|c|c|c|c|c|}
\hline Project & $\mathrm{Key} \mathrm{objectives}$ & Technical Issues & Techoologes & $\begin{array}{l}\text { Deployment } \\
\text { Schedule }\end{array}$ & Applicability to HU & MIY Sivplied & Contacts \\
\hline $\begin{array}{l}\text { GAAT treatability } \\
\text { study W-3 and } \\
\text { W-4 Tanks and } \\
\text { North Tank Farm } \\
\text { ORNL }\end{array}$ & $\begin{array}{l}\text { Waste treatability } \\
\text { issue resolution } \\
\text { Retrieval and } \\
\text { closure criteria } \\
\text { Demonstrate the } \\
\text { ability to retrieve } \\
\text { waste in the } \\
\text { GAAT }\end{array}$ & $\begin{array}{l}\text { Cost effectiveness } \\
\text { of retrieval versus } \\
\text { risk } \\
\text { Retrieval system } \\
\text { effectiveness } \\
\text { Cost effectiveness } \\
\text { of pretreatment, } \\
\text { immobilization } \\
\text { processes }\end{array}$ & $\begin{array}{l}\text { Modified LDUA, } \\
\text { robotic arm } \\
\text { Houdini remote- } \\
\text { control vehicle } \\
\text { Confined sluicing } \\
\text { end effector } \\
\text { Pretreatment } \\
\text { methods }\end{array}$ & Spring 1997 & $\begin{array}{l}\text { Experience with } \\
\text { retrieval system } \\
\text { deployment and } \\
\text { process performance }\end{array}$ & $\begin{array}{l}\text { Understanding of } \\
\text { the processes being } \\
\text { considered at } \\
\text { Hanford for tank } \\
\text { retrieval and } \\
\text { closure. } \\
\end{array}$ & $\begin{array}{l}\text { Dirk Van Hoesen, } \\
\text { LMES } \\
423-574-7264 \\
\text { Jane Powell } \\
\text { DOE-OR, } \\
423-576-7807 \\
\\
\text { Barry Burks, } \\
\text { LMER, 423-576- } \\
7350 \\
\text { Sharon Robinson, } \\
\text { LMER, 423-574- } \\
6779\end{array}$ \\
\hline $\begin{array}{l}\text { Remediation of the } \\
\text { GAAT Operable } \\
\text { Unit. ORNL }\end{array}$ & $\begin{array}{l}\text { Retrieve the waste } \\
\text { from the GAAT } \\
\text { and prepare them } \\
\text { for closure. }\end{array}$ & $\begin{array}{l}\text { Retrieval of waste } \\
\text { from larger (50-ft } \\
\text { dia.) tanks. } \\
\text { Retrieval of waste } \\
\text { from tanks } \\
\text { containing several } \\
\text { feet of sludge. } \\
\text { Tank decontam- } \\
\text { ination } \\
\text { Conditioning of } \\
\text { waste for slurry } \\
\text { transfer to MVST }\end{array}$ & $\begin{array}{l}\text { Modified LDUA, } \\
\text { robotic arm } \\
\text { Houdini remote- } \\
\text { control vehicle } \\
\text { Confined sluicing } \\
\text { end effector } \\
\text { Pretreatment } \\
\text { methods }\end{array}$ & Fall 1998 & $\begin{array}{l}\text { Experience with } \\
\text { retrieval system } \\
\text { deployment and } \\
\text { process performance, } \\
\text { as well as larger scale } \\
\text { field operations }\end{array}$ & \begin{tabular}{|l|} 
HTI Slurry \\
conditioning criteria \\
and on-line slurry \\
monitoring work. \\
\\
Tank closure \\
assessments \\
including NRC \\
"Incidental Waste" \\
determination \\
process.
\end{tabular} & SEE ABOVE \\
\hline
\end{tabular}


Table C-1. Complex-Wide Retrieval and Closure Activities.

\begin{tabular}{|c|c|c|c|c|c|c|c|}
\hline Project & Кеy Objectives & Technical Issues & $\begin{array}{l}\text { Techiologies } \\
\text { mplemented }\end{array}$ & $\begin{array}{l}\text { Boploynent } \\
\text { Schedule }\end{array}$ & Appicability o ofT & $\begin{array}{l}\text { HUI Suplied } \\
\text { Ifrornation }\end{array}$ & Contacts \\
\hline $\begin{array}{l}\text { Old Hydro- } \\
\text { Fracture (OHF) } \\
\text { Tanks } \\
\text { ORNL }\end{array}$ & $\begin{array}{l}\text { Retrieve Waste, } \\
\text { clean out tanks for } \\
\text { closure }\end{array}$ & $\begin{array}{l}\text { Effectiveness of } \\
\text { water monitor type } \\
\text { sluicer }\end{array}$ & \begin{tabular}{|l|}
$\begin{array}{l}\text { Water monitor type } \\
\text { sluicing system }\end{array}$ \\
\end{tabular} & Spring 1998 & $\begin{array}{l}\text { Field experience with } \\
\text { retrieval system } \\
\text { deployment. } \\
\text { Retrieval performance } \\
\text { objectives will be } \\
\text { determined } \\
\text { Permitting issues for } \\
\text { operations }\end{array}$ & $\begin{array}{l}\text { Tank closure } \\
\text { assessments } \\
\text { including NRC } \\
\text { "Incidental Waste" } \\
\text { determination } \\
\text { process. }\end{array}$ & $\begin{array}{l}\text { Clay Bednarz, } \\
\text { LMES, OHF } \\
\text { Mgr.. } \\
423-241-3926\end{array}$ \\
\hline $\begin{array}{l}\text { BVEST } \\
\text { ORNL }\end{array}$ & $\begin{array}{l}\text { Retrieve sludge } \\
\text { waste. } \\
\text { Clean out tanks } \\
\text { for reuse, } \\
\text { removing TRU } \\
\text { contamination }\end{array}$ & \begin{tabular}{|l|} 
Effectiveness of \\
pneumatic- powered \\
water pulse jets \\
(AEA Technology) \\
when deployed \\
through existing \\
tank nozzle sets.
\end{tabular} & $\begin{array}{l}\text { AEA fluidic pulse } \\
\text { jet }\end{array}$ & Fall 1998 & $\begin{array}{l}\text { Retrieval performance } \\
\text { objectives will be } \\
\text { determined }\end{array}$ & $\begin{array}{l}\text { ACTR retrieval } \\
\text { performance data } \\
\text { correlation to AEA } \\
\text { testing results }\end{array}$ & $\begin{array}{l}\text { Sharon Robinson, } \\
\text { IMER, 423-574- } \\
6779\end{array}$ \\
\hline $\begin{array}{l}\text { MVST } \\
\text { ORNL }\end{array}$ & $\begin{array}{l}\text { Retrieve waste for } \\
\text { immobilization and } \\
\text { tank reuse }\end{array}$ & $\begin{array}{l}\text { Privatization of } \\
\text { retrieval processes }\end{array}$ & $\begin{array}{l}\text { Will be selected by } \\
\text { the private vendor. }\end{array}$ & $\begin{array}{l}\text { RFP- Winter } \\
1997 \\
\\
\text { Retrieval } \\
\text { Operations- } \\
\text { Fall } 2001\end{array}$ & $\begin{array}{l}\text { Specification for } \\
\text { private vendor } \\
\text { retrieval of tank waste }\end{array}$ & $\begin{array}{l}\text { Review and } \\
\text { comment on } \\
\text { retrieval } \\
\text { specification }\end{array}$ & $\begin{array}{l}\text { Sharon Robinson, } \\
\text { LMER, 423-574- } \\
6779\end{array}$ \\
\hline
\end{tabular}


Table C-1. Complex-Wide Retrieval and Closure Activities.

\begin{tabular}{|c|c|c|c|c|c|c|c|}
\hline Project & $\mathrm{Key}$ objectives & Tecbinical Issues & Techoologies & $\begin{array}{l}\text { Doployment } \\
\text { sclectule }\end{array}$ & Applicability to HI & $\begin{array}{l}\text { HIY SUpplied } \\
\text { lnformation }\end{array}$ & Contacs \\
\hline $\begin{array}{l}\text { V-9 Tank (Smal1 } \\
\text { Filter Tank) } \\
\text { Stabilization and } \\
\text { Closure } \\
\text { INEL }\end{array}$ & $\begin{array}{l}\text { Waste stabilization } \\
\text { and closure of a } \\
\text { V-tank } \\
\text { Closure criteria } \\
\text { for V-tanks }\end{array}$ & $\begin{array}{l}\text { Sample and } \\
\text { characterize waste } \\
\text { Determine } \\
\text { effectiveness of } \\
\text { grout injection for } \\
\text { stabilization } \\
\text { Removal and } \\
\text { destructive analysis } \\
\text { of tank }\end{array}$ & $\begin{array}{l}\text { Grout injection for } \\
\text { waste stabilization }\end{array}$ & \begin{tabular}{|l|} 
Field demo in \\
FY 1997 \\
Monitoring, \\
destructive \\
analysis, and \\
reporting in \\
FY 1998
\end{tabular} & $\begin{array}{l}\text { Use of grout } \\
\text { immobilization as a } \\
\text { technique for tank } \\
\text { stabilization }\end{array}$ & $\begin{array}{l}\text { Collaboration on } \\
\text { specifications }\end{array}$ & $\begin{array}{l}\text { Betsy Jonker, } \\
\text { DOE-OR, } \\
\text { 208-526-9855 } \\
\text { Gretchen Matthern, } \\
\text { LMIT, } \\
\text { 208-526-8747 } \\
\\
\text { Dick Meservey, } \\
\text { LMTT, } \\
\text { 208-526-1834 }\end{array}$ \\
\hline $\begin{array}{l}\text { V-Tank Closure } \\
\text { INEL }\end{array}$ & $\begin{array}{l}\text { Close CERCLA } \\
\text { Tanks }\end{array}$ & $\begin{array}{l}\text { Retrieval } \\
\text { performance criteria } \\
\text { Closure Criteria } \\
\text { determination }\end{array}$ & $\begin{array}{l}\text { This will be } \\
\text { determined by the } \\
\text { approved } \\
\text { remediation plan }\end{array}$ & \begin{tabular}{|l|} 
ROD - \\
FY 1998 \\
Remediation \\
FY 1999, FY \\
2000
\end{tabular} & $\begin{array}{l}\text { Field experience with } \\
\text { retrieval system } \\
\text { deployment. } \\
\text { Retrieval performance } \\
\text { objectives will be } \\
\text { determined } \\
\text { Permitting issues for } \\
\text { operations }\end{array}$ & $\begin{array}{l}\text { Feedback from HTI } \\
\text { retrieval } \\
\text { performance } \\
\text { objectives and } \\
\text { results from } \\
\text { retrieval technology } \\
\text { screening and } \\
\text { testing. }\end{array}$ & See Above \\
\hline
\end{tabular}


Table C-1. Complex-Wide Retrieval and Closure Activities.

\begin{tabular}{|c|c|c|c|c|c|c|c|}
\hline $\mathrm{Profect}$ & Key Objectives & Technical Issues & $\begin{array}{l}\text { Technologies } \\
\text { Implenented }\end{array}$ & $\begin{array}{l}\text { Deppoyment } \\
\text { schedule }\end{array}$ & Applicability to HTI & $\begin{array}{l}\text { HTS Sipplied } \\
\text { Siformation }\end{array}$ & Contacts: \\
\hline $\begin{array}{l}\mathrm{F} \text {-Tank Farm } \\
\text { Closure Tanks } \\
17-20 \mathrm{~F} \\
\text { SRS }\end{array}$ & $\begin{array}{l}\text { Declare tanks out } \\
\text { of service and } \\
\text { ready for closure } \\
\text { Retrieval of heel } \\
\text { wastes for tank } \\
\text { closure as required }\end{array}$ & $\begin{array}{l}\text { Source term of heel } \\
\text { waste } \\
\text { Performance } \\
\text { objectives for tank } \\
\text { residual waste } \\
\text { Stabilization of } \\
\text { tank } \\
\text { NRC "Incidental } \\
\text { Waste" } \\
\text { determination }\end{array}$ & \begin{tabular}{|l|} 
Closure \\
performance \\
evaluation
\end{tabular} & $\begin{array}{l}\text { Complete } \\
\text { closure } \\
\text { Tank 20- } \\
\text { FY 1997 } \\
\text { Tank 17 } \\
\text { FY } 1997 \\
\\
\text { Tank 19 } \\
\text { FY 1999 } \\
\text { Tank 18 } \\
\text { FY- 2000 }\end{array}$ & $\begin{array}{l}\begin{array}{l}\text { Development of } \\
\text { closure criteria }\end{array} \\
\text { Closure methods } \\
\text { Closure performance } \\
\text { assessment } \\
\text { NRC classification } \\
\text { of residual waste } \\
\text { Tank Stabilization } \\
\text { methods }\end{array}$ & $\begin{array}{l}\text { Understanding of } \\
\text { the processes being } \\
\text { considered at } \\
\text { Hanford for tank } \\
\text { retrieval and } \\
\text { closure. }\end{array}$ & $\begin{array}{l}\text { Eloy Saldivar, } \\
\text { WSRC, 803-208- } \\
\text { 0264 } \\
\text { Sharon Marra, } \\
\text { WSRC, 803-208-. } \\
\text { O497 } \\
\text { Neil Davis, WSRC } \\
\text { 803-725-1246 } \\
\\
\text { Larry Ling DOE- } \\
\text { SR 803-208-8248 }\end{array}$ \\
\hline $\begin{array}{l}\text { Tank } 25 / 41 \text { Salt } \\
\text { Retrieval } \\
\text { SRS }\end{array}$ & \begin{tabular}{|l|} 
Test alternative \\
retrieval \\
technologies to \\
replace expensive \\
large mixer pumps \\
for salt retrieval \\
\end{tabular} & $\begin{array}{l}\text { Slower dissolution } \\
\text { of salt cake } \\
\text { Reduce need for } \\
\text { expensive mixer } \\
\text { pump } \\
\text { Retrieve insoluble } \\
\text { waste }\end{array}$ & $\begin{array}{l}\text { AEA Fluidic Diode } \\
\text { Transfer Pump } \\
\text { Water monitor } \\
\text { sluicer for } \\
\text { retrieving salt from } \\
\text { tank upper } \\
\text { structure and bulk } \\
\text { salt dissolution }\end{array}$ & FY 1999 & $\begin{array}{l}\text { Technique for salt } \\
\text { cake removal by } \\
\text { sluicing for HTI } \\
\text { follow-on. } \\
\text { Experience with } \\
\text { retrieval system } \\
\text { deployment and } \\
\text { process performance }\end{array}$ & $\begin{array}{l}\text { Results from } \\
\text { retrieval technology } \\
\text { screening and } \\
\text { testing. }\end{array}$ & $\begin{array}{l}\text { Eloy Saldivar, } \\
\text { WSRC, 803-208- } \\
\text { O264 } \\
\text { Tom Gutmann, } \\
\text { DOE-SR } \\
803-208-1464\end{array}$ \\
\hline
\end{tabular}




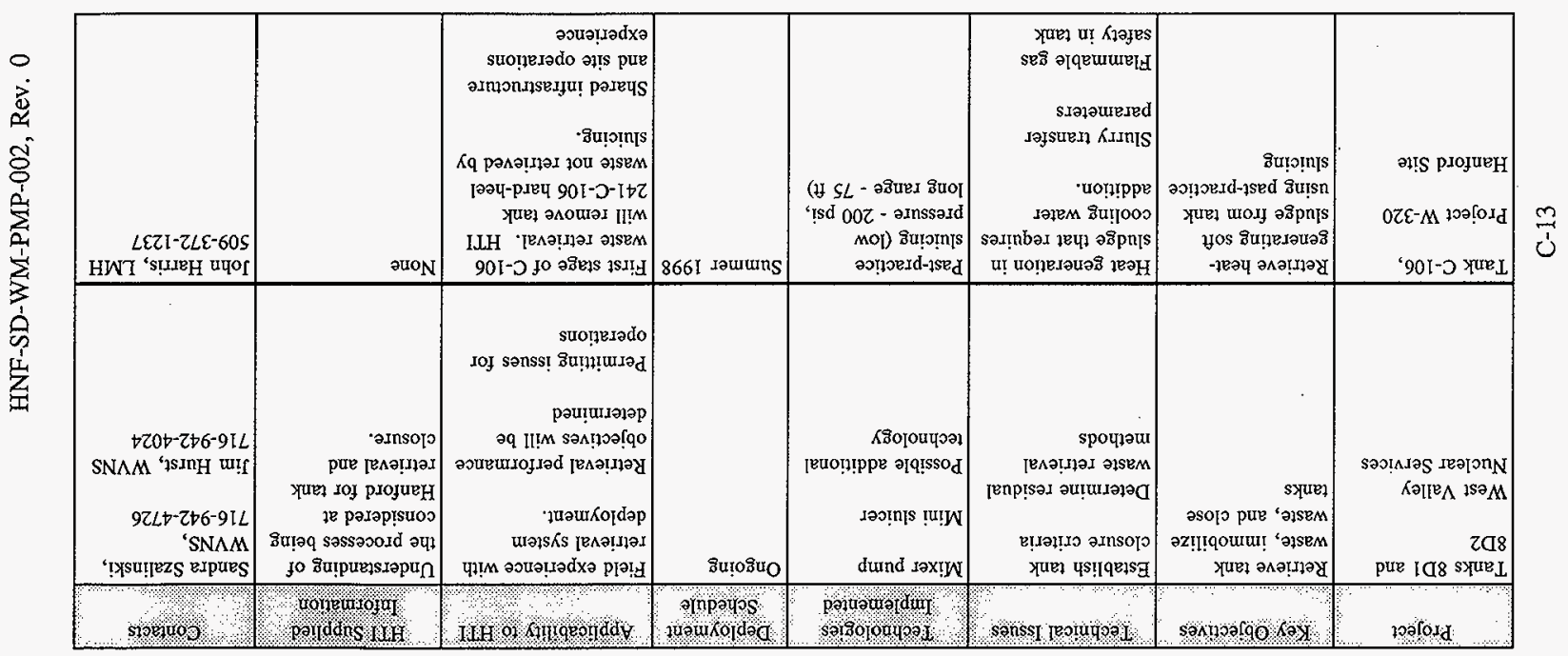

'sə!!! 
Table C-1. . Complex-Wide Retrieval and Closure Activities.

\begin{tabular}{|c|c|c|c|c|c|c|c|}
\hline Project & Key objectives & Technidal Issues & $\begin{array}{l}\text { Technologles } \\
\text { Mnplemented }\end{array}$ & $\begin{array}{l}\text { Deploynent. } \\
\text { Schedule. }\end{array}$ & Applicability to LII & MIn Siplized & Contacts \\
\hline $\begin{array}{l}\text { HTI } \\
\text { (Includes ACTR } \\
\text { work) } \\
\text { Hanford Site }\end{array}$ & $\begin{array}{l}\text { Develop tool box } \\
\text { of retrieval and } \\
\text { deployment } \\
\text { systems and } \\
\text { processes } \\
\text { Retrieve hard- } \\
\text { heel waste from } \\
\text { tank C-106 } \\
\\
\text { Close tank AX- } \\
104 \text { (small amount } \\
\text { of residual waste) }\end{array}$ & $\begin{array}{l}\text { Effectiveness and } \\
\text { availability of } \\
\text { commercial } \\
\text { technologies } \\
\text { Provide retrieval } \\
\text { and deployment } \\
\text { concepts } \\
\text { Identify industrial } \\
\text { sources of retrieval } \\
\text { and deployment } \\
\text { equipment }\end{array}$ & $\begin{array}{l}\text { MPW water jet } \\
\text { technology, ARD } \\
\text { vehicle-based tank- } \\
\text { cleaning service } \\
\\
\text { Gray Pilgrim, } \\
\text { novel in-tank } \\
\text { manipulator; } \\
\text { Bristol water } \\
\text { monitor }\end{array}$ & \begin{tabular}{|l|} 
Retrieve \\
C-106 heel \\
FY 1999 \\
Closure \\
performance \\
data for AX- \\
104 \\
FY 2000
\end{tabular} & N/A & N/A & $\begin{array}{l}\text { Bill Root, } \\
\text { Informatics 509- } \\
376-1338 \\
\\
\text { Larry McDaniel, } \\
\text { NHC, } \\
509-372-0305 \\
\\
\text { Ed Fredenburg, } \\
\text { NHC 509-372- } \\
0435 \\
\text { Jeff Voogd LMH, } \\
509-373-4101 \\
\\
\text { Jim Yount, PNNL } \\
509-376-3284\end{array}$ \\
\hline $\begin{array}{l}\text { Hanford SST } \\
\text { Waste Retrieval, } \\
\text { Phase 2 } \\
\text { Privatization }\end{array}$ & $\begin{array}{l}\text { Retrieval of SST } \\
\text { wastes for tank } \\
\text { closure }\end{array}$ & $\begin{array}{l}\text { Closure criteria, } \\
\text { retrieve experience } \\
\text { to form bases for } \\
\text { competitive bid. }\end{array}$ & $\begin{array}{l}\text { Will be selected by } \\
\text { the privatization } \\
\text { vendor }\end{array}$ & $\begin{array}{l}\text { Procurement } \\
\text { specification } \\
\text { must be in } \\
\text { place by } 2003\end{array}$ & N/A & $\begin{array}{l}\text { HTI will provide } \\
\text { baseline for SST } \\
\text { retrieval, enabling } \\
\text { industry to } \\
\text { confidently propose } \\
\text { on Phase II } \\
\text { privatization }\end{array}$ & $\begin{array}{l}\text { William J. Taylor, } \\
\text { DOE-RL, } \\
\text { 509-372-3864 }\end{array}$ \\
\hline
\end{tabular}


Table C-1. Complex-Wide Retrieval and Closure Activities.

\begin{tabular}{|c|c|c|c|c|c|c|c|}
\hline Project & Key objectives & Technical Issues & Ternologits & $\begin{array}{l}\text { Deploy rient } \\
\text { schedule }\end{array}$ & Apploablits o HA & $\begin{array}{l}\text { MI Supplied } \\
\text { information }\end{array}$ & Cofinets, \\
\hline $\begin{array}{l}\text { Silo Remediation } \\
\text { Fernald }\end{array}$ & $\begin{array}{l}\text { Retrieve waste } \\
\text { from silos and } \\
\text { transfer to } \\
\text { vitrification } \\
\text { facility }\end{array}$ & $\begin{array}{l}\text { Retrieval system } \\
\text { performance } \\
\text { Waste Transfer } \\
\text { Issues } \\
\text { Silo closure }\end{array}$ & $\begin{array}{l}\text { Hydraulic spray- } \\
\text { jetpump mining } \\
\text { tool } \\
\text { Sluicer } \\
\text { Houdini, remote- } \\
\text { control vehicle } \\
\text { system }\end{array}$ & \begin{tabular}{|l} 
Start \\
Retrieval \\
FY 2000 \\
[TBD]
\end{tabular} & $\begin{array}{l}\text { Retrieval Performance } \\
\text { data. } \\
\text { Site Operations } \\
\text { Experience } \\
\text { Closure Criteria }\end{array}$ & \begin{tabular}{|l|} 
HTI slurry \\
conditioning criteria \\
and on-line slurry \\
monitoring work. \\
\\
Tank closure \\
assessments \\
including NRC \\
"Incidental Waste" \\
determination \\
process.
\end{tabular} & $\begin{array}{l}\text { F. Brack Hazen, } \\
\text { FERMCO } \\
513-648-6554\end{array}$ \\
\hline
\end{tabular}

$\frac{2}{4}$ 
Table C-2. Listing of Technologies with Potential to Support the Hanford Tanks Initiative.

\begin{tabular}{|c|c|c|}
\hline Technology & Description & Maturity \\
\hline$\forall \quad \because$ & PreRetrievaleharacternation & \\
\hline \multicolumn{3}{|l|}{ In Situ Measurement } \\
\hline \multirow[t]{2}{*}{$\begin{array}{l}\text { Acoustic imaging and density } \\
\text { monitor }\end{array}$} & $\begin{array}{l}\text { Acoustic characterization } \\
\text { (solid/liquid interface and relative } \\
\text { slurry density) of wastes to assist the } \\
\text { retrieval of the double-shell tanks }\end{array}$ & Available now \\
\hline & $\begin{array}{l}\text { Acoustic particle size measurement, } \\
\text { low-power slurry density } \\
\text { determination }\end{array}$ & $\begin{array}{l}\text { In lab in } 1996 \text { (go), could be used } \\
\text { in } 1998\end{array}$ \\
\hline $\begin{array}{l}\text { In situ CPT with Raman } \\
\text { spectral analysis probe }\end{array}$ & $\begin{array}{l}\text { Measure the chemical composition } \\
\text { of tank waste in situ, determine } \\
\text { rheological and moisture properties } \\
\text { of tank waste matrix }\end{array}$ & $\begin{array}{l}\text { Under construction, needs site } \\
\text { hand-off }\end{array}$ \\
\hline $\begin{array}{l}\text { Neural network for Raman- } \\
\text { equipped CPT signal } \\
\text { extraction and enhancement }\end{array}$ & $\begin{array}{l}\text { On-line analysis for tank waste using } \\
\text { Raman spectral analysis }\end{array}$ & In lab \\
\hline $\begin{array}{l}\text { LDUA system minilab end } \\
\text { effector }\end{array}$ & $\begin{array}{l}\text { Conduct in situ measurements of } \\
\text { waste composition within the tank }\end{array}$ & $\begin{array}{l}\text { Component testing in progress, } \\
\text { fabrication in } 1997\end{array}$ \\
\hline \multicolumn{3}{|l|}{ Sampling and Analysis } \\
\hline Chemical analysis automation & $\begin{array}{l}\text { Automated sample preparation and } \\
\text { analysis for analysis of contaminated } \\
\text { media in a standard and mobile } \\
\text { laboratory, currently focused on } \\
\text { organic and heavy metal analysis. }\end{array}$ & $\begin{array}{l}\text { Built and tested for contaminated } \\
\text { soil analysis. Industry partner on } \\
\text { board }\end{array}$ \\
\hline $\begin{array}{l}\text { ICP-MS for analysis of } \\
\text { Microliter samples and solids }\end{array}$ & $\begin{array}{l}\text { Determine and quantify the chemical } \\
\text { content within tank waste using very } \\
\text { small samples complying with } \\
\text { ALARA criteria. }\end{array}$ & In lab \\
\hline \multicolumn{3}{|l|}{ Characterization Support } \\
\hline LDUA system & $\begin{array}{l}\text { Deploy tools for sampling tank } \\
\text { wastes, especially residual heel } \\
\text { waste and surveying tank interior. } \\
\text { Designed for flammable atmosphere. }\end{array}$ & $\begin{array}{l}\text { Onsite, completed initial hot } \\
\text { deployment }\end{array}$ \\
\hline LDUA TMS & $\begin{array}{l}\text { Help determine the volume and } \\
\text { location of remaining waste heel. }\end{array}$ & $\begin{array}{l}\text { Field unit was tested 6/96, will be } \\
\text { deployed at ORNL Spring } 1997\end{array}$ \\
\hline Ultrasonic imaging & $\begin{array}{l}\text { Ultrasonic imaging for solid/liquid } \\
\text { flows }\end{array}$ & \\
\hline Gamma mapping & $\begin{array}{l}\text { Gamma radiation levels to be } \\
\text { measured in predetermined locations }\end{array}$ & $\begin{array}{l}\text { Probe needs to be modified for } \\
\text { remote handling }\end{array}$ \\
\hline \multicolumn{3}{|l|}{ Pre-sluicing } \\
\hline $\begin{array}{l}\text { Electrical resistance } \\
\text { tomography for subsurface } \\
\text { imaging }\end{array}$ & $\begin{array}{l}\text { Detect the amount of moisture } \\
\text { transport from previous leaks. }\end{array}$ & $\begin{array}{l}\text { Low confidence for monitoring old } \\
\text { or new leakage. }\end{array}$ \\
\hline
\end{tabular}


HNF-SD-WM-PMP-022, Rev. 0

Table C-2. Listing of Technologies with Potential to Support the Hanford Tanks Initiative.

\begin{tabular}{|c|c|c|}
\hline Technology & Description & Maturity \\
\hline \multicolumn{3}{|c|}{ Retreval } \\
\hline \multicolumn{3}{|l|}{ Retrieval Support } \\
\hline LDUA system & $\begin{array}{l}\text { Recover and repair broken devices, } \\
\text { relocate small in-tank equipment, } \\
\text { and perform small-scale retrieval } \\
\text { tasks. }\end{array}$ & $\begin{array}{l}\text { Onsite, completed first hot } \\
\text { deployment. }\end{array}$ \\
\hline Houdini & $\begin{array}{l}\text { Recover and repair broken devices, } \\
\text { relocate small in-tank equipment, } \\
\text { and perform retrieval tasks. }\end{array}$ & $\begin{array}{l}\text { Will be deployed in ORNL tanks in } \\
\text { early FY } 1997\end{array}$ \\
\hline \multicolumn{3}{|l|}{ Retrieval Enhancements } \\
\hline Enhanced unconfined sluicing & $\begin{array}{l}\text { Improvements to past-practice } \\
\text { slicing ( } 200 \mathrm{psi}, 100 \mathrm{gal} / \mathrm{min}) \text {. }\end{array}$ & FY 1997,1998 \\
\hline Pulse-Air (Reg. TM) & $\begin{array}{l}\text { Mixing by large bubbles. Suitable } \\
\text { for process or conditioning; tank } \\
\text { mixing. Could be used for in-tank } \\
\text { grout mixing. }\end{array}$ & $\begin{array}{l}\text { Commercially available, } \\
\text { proprietary. Has not been deployed } \\
\text { in large tanks }\end{array}$ \\
\hline Borehole mining & $\begin{array}{l}\text { Unconfined sluicer ( } 500 \text { to } 3,000 \text { psi } \\
\text { at } 75 \text { to } 150 \mathrm{gal} / \mathrm{min} \text { ) that can be } \\
\text { deployed with integral pump through } \\
\text { a } 30 \mathrm{~cm} \text { ( } 12 \text {-in.) access port. }\end{array}$ & Commercially available \\
\hline $\begin{array}{l}\text { Confined sluicing scarifier } \\
\text { with jet pump }\end{array}$ & $\begin{array}{l}10,000 \text { psi waterjet scarifier used } \\
\text { with the jet pump conveyance (low } \\
\text { water addition); weighs } 25 \mathrm{lbs} \text {. }\end{array}$ & $\begin{array}{l}\text { Ready for testing. To be deployed } \\
\text { for waste retrieval at ORNL } 11 / 96 \text {. }\end{array}$ \\
\hline Light-weight scarifier & $\begin{array}{l}50,000 \text { psi water jet scarifier used } \\
\text { with air conveyance (low water } \\
\text { addition, for stubborn waste forms); } \\
\text { weighs } 50 \mathrm{lbs} \text {. }\end{array}$ & $\begin{array}{l}\text { Prototype has been built; ready for } \\
\text { testing. }\end{array}$ \\
\hline \multicolumn{3}{|l|}{ ACTR } \\
\hline Retrieval database & $\begin{array}{l}\text { Determine commercially available } \\
\text { best approaches to retrieving waste. } \\
\text { Develop applicability of database } \\
\text { based on site conditions and desired } \\
\text { results. }\end{array}$ & Available FY-1997 \\
\hline $\begin{array}{l}\text { Vehicle-based tank cleaning } \\
\text { services }\end{array}$ & $\begin{array}{l}\text { ARD, Inc., has experience cleaning } \\
\text { flammable tanks for the petroleum } \\
\text { industry and contaminated sludge } \\
\text { from commercial power reactor fuel } \\
\text { basins. }\end{array}$ & Open for business. \\
\hline $\begin{array}{l}\text { Waterjet tank cleaning } \\
\text { services }\end{array}$ & $\begin{array}{l}\text { MPW, Inc., has experience cleaning } \\
\text { tanks using high pressure water jets. }\end{array}$ & Open for business \\
\hline Grey pilgrim manipulator & $\begin{array}{l}\text { Novel cable-tendon manipulator with } \\
\text { flexible duct. No in-tank actuators. }\end{array}$ & Prototype has been built by METC. \\
\hline
\end{tabular}


Table C-2. Listing of Technologies with Potential to Support the Hanford Tanks Initiative.

\begin{tabular}{|c|c|c|}
\hline Technology & Description & Maturity \\
\hline \multicolumn{3}{|l|}{ Process Monitoring During Sluicing } \\
\hline $\begin{array}{l}\text { ERT with CPT emplacement } \\
\text { leak detection and monitoring }\end{array}$ & $\begin{array}{l}\text { Determine extent of tank leakage } \\
\text { during retrieval operations. Not } \\
\text { necessarily an early-warning leak } \\
\text { detection system. }\end{array}$ & $\begin{array}{l}\text { Tank farm deployment will be } \\
\text { addressed in FY } 1997 .\end{array}$ \\
\hline $\begin{array}{l}\text { In situ viscosity and density } \\
\text { monitoring using quartz } \\
\text { resonators }\end{array}$ & $\begin{array}{l}\text { Measures density and viscosity of } \\
\text { mixed-waste tank slurries during } \\
\text { pipeline transport. }\end{array}$ & Successful lab test \\
\hline \multicolumn{3}{|c|}{ post Retrieval } \\
\hline Houdini & $\begin{array}{l}\text { Provide vehicle to determine } \\
\text { residual tank waste volume and } \\
\text { characteristics, and to } \\
\text { decontaminate and decommission } \\
\text { tanks. }\end{array}$ & $\begin{array}{l}\text { Platform will be deployed in ORNL } \\
\text { tanks in early FY } 1997 .\end{array}$ \\
\hline LDUA & $\begin{array}{l}\text { Provide a means to determine } \\
\text { residual tank waste volume. }\end{array}$ & $\begin{array}{l}\text { Onsite, deployed in a hot tank in } \\
9 / 96 .\end{array}$ \\
\hline \multicolumn{3}{|c|}{ Stabilization/olosure } \\
\hline $\begin{array}{l}\text { In situ grouting and grout } \\
\text { injection }\end{array}$ & Stabilize tank residuals. & $\begin{array}{l}\text { Under consideration at SRS. Will } \\
\text { be tested at INEL in FY 1996/ } \\
1997 .\end{array}$ \\
\hline Closure criteria & $\begin{array}{l}\text { Evaluate release and transport of } \\
\text { contaminant residual waste and the } \\
\text { effects of their transport through the } \\
\text { vadose zone and aquifer. }\end{array}$ & $\begin{array}{l}\text { Ongoing in support of closure of } \\
\text { Hanford Site tanks. }\end{array}$ \\
\hline
\end{tabular}

$\begin{array}{ll}\text { ACTR } & =\text { Acquire Commercial Technology for Retrieval } \\ \text { ALARA } & =\text { as low as reasonably achievable } \\ \text { CPT } & =\text { cone penetrometer technique } \\ \text { ERT } & =\text { electrical resistance tomography } \\ \text { ICP-MS } & =\text { inductively coupled plasma-mass spectrometry } \\ \text { INEL } & =\text { Idaho National Engineering Laboratory } \\ \text { LDUA } & =\text { light-duty utility arm } \\ \text { METC } & =\text { Morgantown Energy Technology Center } \\ \text { ORNL } & =\text { Oak Ridge National Laboratory } \\ \text { SRS } & =\text { Savannah River Site } \\ \text { TMS } & =\text { topographical mapping system }\end{array}$


HNF-SD-WM-PMP-022, Rev. 0

APPENDRX D

PROGRAMMATIC RISK ASSESSMENT

$D-i$ 
HNF-SD-WM-PMP-022, Rev. 0

This page intentionally left blank.

D-ii 


\section{D.0 INTRODUCTION}

Risk planning, assessment, analyses, and management (Figure D-1) will be used throughout the HTT Project to identify significant risk factors and formulate mitigation plans. Identified risks will be incorporated into the TWRS risk management list for assessment and analyses in conjunction with those of the waste retrieval project and the storage and disposal project. Risk assessment will be an ongoing, iterative, integrated process providing information needed to manage programmatic and technical risk.

As the HTI Project progresses from initial mission analysis through demonstrations, additional risk assessments and analyses will be performed. Dimensions of both programmatic and environmental, safety and health risks will be assessed. During early stages of the project, assessments of risk will be predominantly qualitative. During later phases, risk will be evaluated quantitatively as well.

Initial risk screening was conducted by the project team as part of this project plan. The risk-screening topics included technology, time, contractor capabilities, interfaces, safety, environmental, regulatory involvement, political visibility, key participants, complexity, labor, locations, funding, quality, and stakeholder involvement.

\section{D.1 PERCEIVED SOURCES OF HIGH RISKS}

Based on the risk-screening process conducted as part of the project planning process, the following were perceived as potential sources of high risk:

- Uncertainties that may impact the completion schedules

- The regulatory process, including stakeholder and Indian Nation involvement, may not support the aggressive four-year schedule. Availability and capability of staff to participate as a team may be limited by the available resources and competing priorities. Planned actions to manage this risk are addressed in the stakeholder involvement strategy section of this plan (Section 7.0). Stakeholder input will be closely monitored by the project. The impacts of schedule slippage, if any, will be assessed as the HTI Project progresses. Analysis will be made of actions taken to address potential schedule and cost problems, as well as opportunities. 
Figure D-1. Programmatic Risk Management Process.

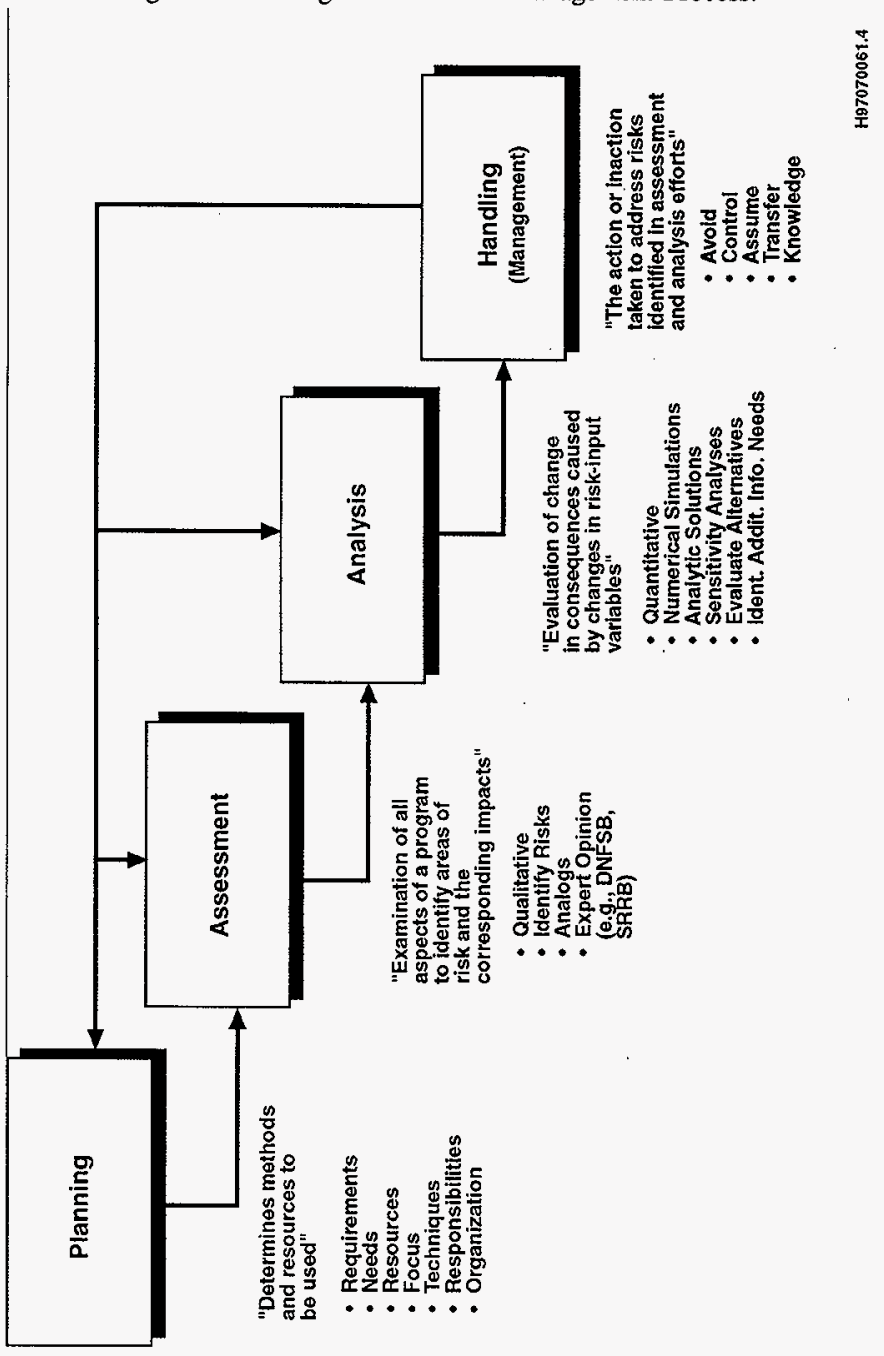


- Waste characterization and retrieval uncertainties that affect radiological and hazardous material safety

- The current safety basis does not include the retrieval of tank waste. The operating environment and performance requirements will be specified before the solicitation of bids for waste retrieval. After vendors are identified then safety analysis reviews will be made on the technology to be tested in the tanks to ensure compatibility with the residual waste. Planned actions are addressed in the safety strategy section of this plan (Appendix E).

- Uncertainties related to regulatory authorities and changing regulations

- The retrieval of hard-heel waste from tank 241-C-106 will accelerate the schedule for compliance with Milestone M-45-03. However, the process, requirements, and criteria are not yet defined. In addition, multiple agencies will be involved in the regulatory process (i.e., Ecology, WDOH, and the NRC).

One HTI Project objective is to provide a basis for the future performance requirements for the Phase II privatization of waste retrieval. Achievement of this HTI Project objective through management of HTI programmatic risks will reduce the subsequent programmatic risk in completing the overall TWRS mission.

\section{D.2 DECISION LOGIC}

Major decisions are shown in Figure D-2. The first major decision is approval of the mission and this project plan. The next major decision is selection of specific tanks for the hard-heel waste retrieval and closure-readiness assessment. This project plan assumes that tanks 241-C-106 and 241-AX-104 are candidates. These decisions are followed by agreement with regulators and stakeholders on the criteria for retrieval and closure performance evaluations.

The decision logic follows two paths (one for retrieval and one for closure). The retrieval technology will be selected from the field-tested technologies. Following selection of the technologies, project decisions will be made regarding installation and removal of equipment, operations, and acceptance of completion of waste removal.

The closure path requires verification that the cleaned-out tank complies with retrieval performance criteria, including NRC non-HLW determination. If the tank does not comply with the criteria, additional waste retrieval may be required, impacting planned cost and schedule. 
Figure D-2. Abbreviated Decision Logic.

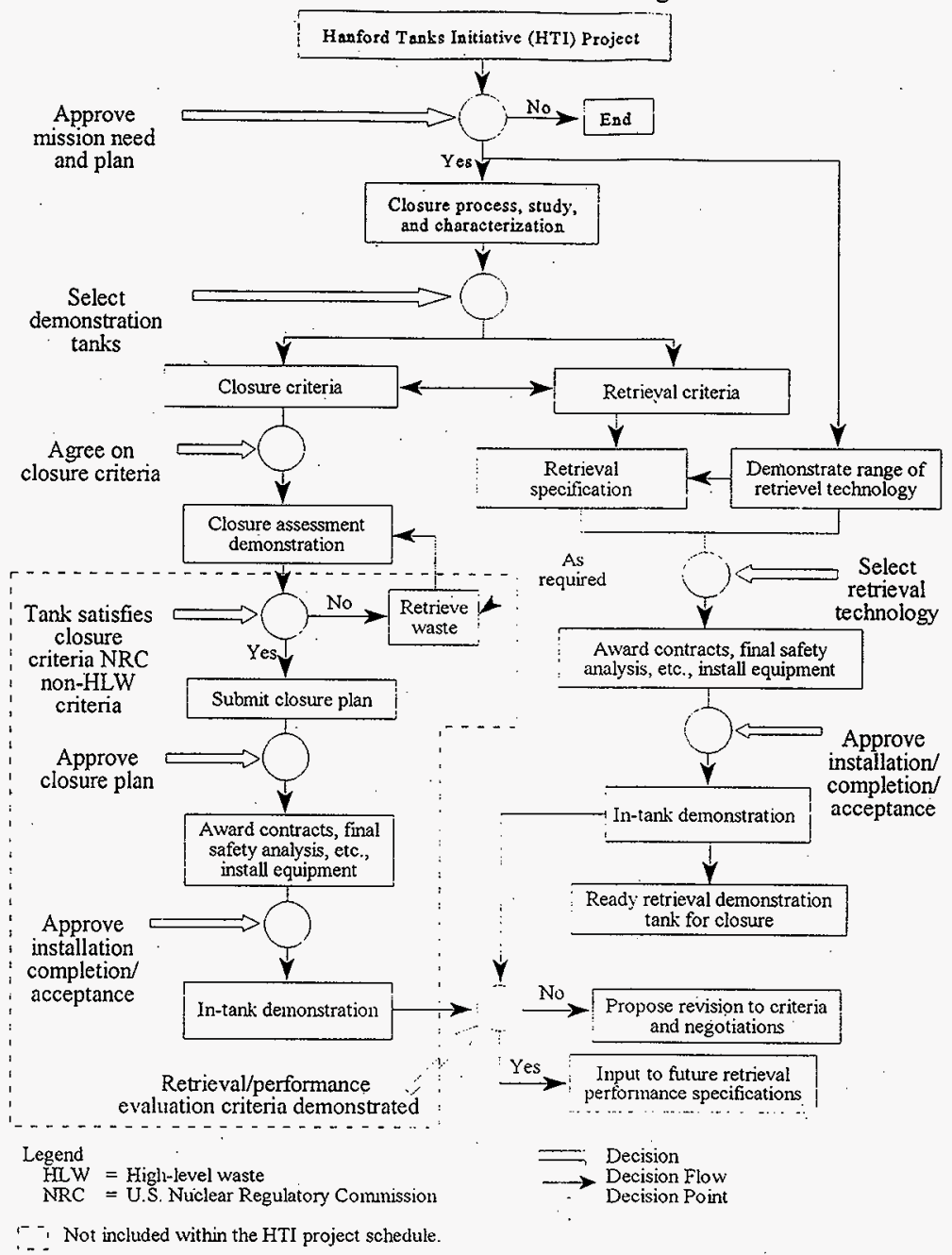


The portion of the closure logic path following the "closure assessment" is enclosed in a dashed-line boundary (Figure D-2). Activities and decisions within this boundary are constrained by planned activities to test the capability of waste retrieval technology in the first SST farm, in accordance with the Tri-Party Agreement. Accordingly, these activities are outside the currently planned HTI scope and schedule.

At the end of the HTI Project, an evaluation will be made of the success of the HTI in retrieval and closure assessment technologies. The results of the evaluation testing will be factored into planning for waste retrieval from the remaining SSTs. 
HNF-SD-WM-PMP-022, Rev. 0

This page intentionally left blank. 
HNF-SD-WM-PMP-022, Rev. 0

APPENDIX E

SAFETY PROGRAM IMPLEMENTATION 
HNF-SD-WM-PMP-022, Rev. 0

This page intentionally left blank. 


\section{E.0 INTRODUCTION}

The HTI has several safety objectives that will be achieved by using a full complement of safety program elements and DOE authorizations to implement the retrieval, characterization, and closure basis actions. HT''s safety program objective is to place worker and public safety above all else. To support the HTI Project the following strategies will be employed:

- Manage the HTI Nuclear Safety and Licensing efforts to support the technical schedule

- Maintain cognizance with evolving tank farm safety bases

- Establish a safety basis for future retrieval and closure activities, as funds and time allow.

\section{E.1 IMPLEMENTATION}

The means by which the nuclear safety and licensing program will interface with the HTI will include safety analyses, training, procedures, equipment specifications, and operational controls. The major steps for the nuclear safety and licensing support to HTI are shown in Figure E-1. These actions will be initiated by means of a review of proposed HTI activities and relevant technologies proposed for use during retrieval and closure. TFA and ACTR activities and technologies will be reviewed, as needed based on the existing safety basis. This review will also assess supplemental safety analyses that may have been completed for technologies and that are not included in the current TWRS safety basis. The intent of these reviews is to minimize schedule impacts that safety analyses might have on the work. The reviews will also aid in assessing the breadth of future safety-basis needs.

A critical path HTI activity will likely be completion of the safety analyses. A two-part process will be used to expedite completion and implementation of the safety program.

1. Existing safety analyses will be evaluated based on several predecessor activities:

- The results of Project W-340 for the TFA

- The results of Project W-320

- $\quad$ SRS tank waste retrieval and closure

- TFA activities related to specific technologies

- LDUA deployment for waste characterization in tank 241-T-106.

2. Results of contractor activities will be used to prepare safety analysis documentation. 
HNF-SD-WM-PMP-022, Rev. 0

Figure E-1. HTI Safety and Licensing Procurement Support.

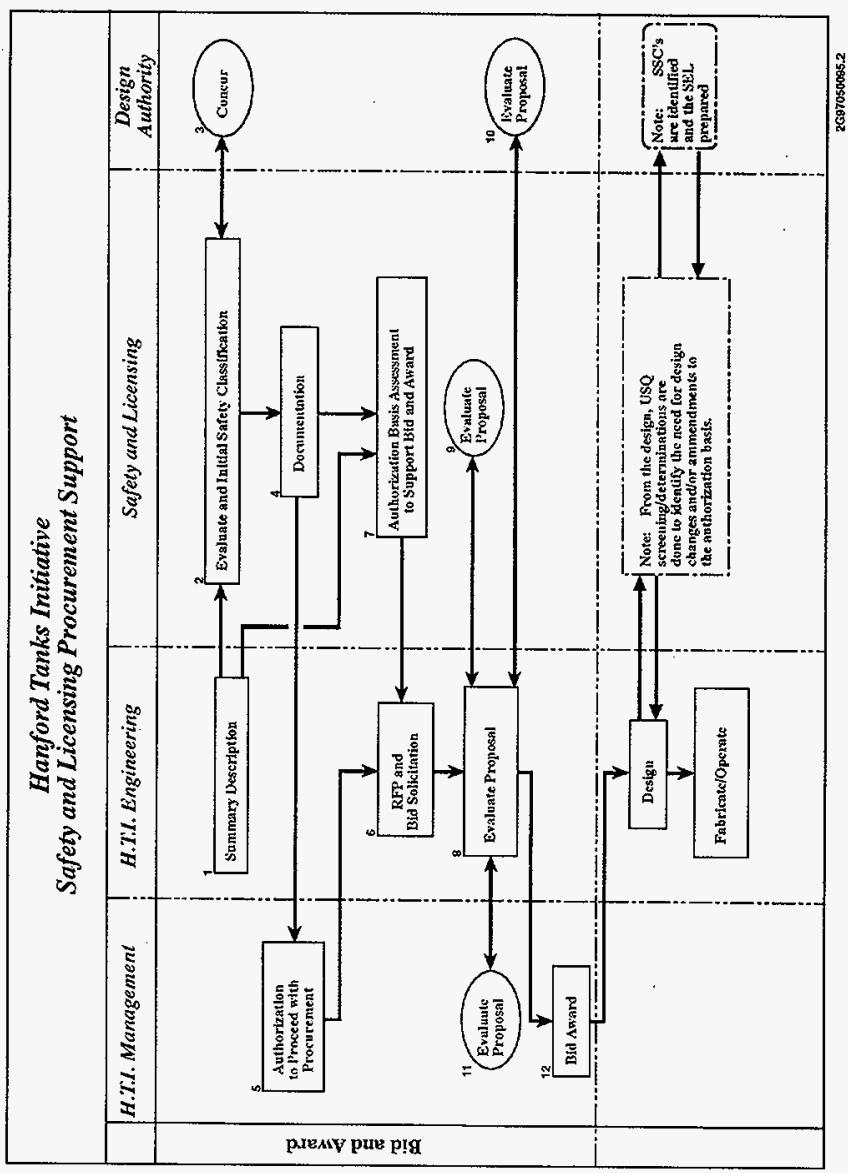


As time and funding allow, the HTI will establish an initial safety basis for future retrieval and closure-readiness activities. The HTI activities will utilize a wide range of technologies for entering and conducting operations within tanks with large or small amounts of waste. The HTI will provide a "lessons-learned" repository for expansion of the safety basis to future retrieval and closure activities. This experience will provide increased specificity to issues and activities necessary to successfully complete future waste retrieval and tank closure safety activities.

Several factors will require close management attention to waste retrieval and closure-readiness safety issues:

- New safety regulations are currently being implemented throughout the DOE complex

- TWRS updates of the authorization basis for tank farm operations

- Safety documentation prepared for Project W-320 tank 241-C-106 sluicing retrieval

- Multiple review authorities for a Final Safety Analysis Report (FSAR).

Each of the above factors can influence the scope of the HTI safety program.

The current estimated costs and schedules include several assumptions. The authorization basis for HTI activities will be the Basis for Interim Operation (BIO), which will eventually be succeeded by the FSAR. Activities not bounded by the BIO (or FSAR) will require approval of a safety assessment before they can be implemented. 
HNF-SD-WM-PMP-022, Rev. 0

This page intentionally left blank. 
HNF-SD-WM-PMP-022, Rev. 0

APPENDIX F

RESOURCE PLAN

$\mathrm{F}-\mathrm{i}$ 
HNF-SD-WM-PMP-022, Rev. 0

This page intentionally left blank. 


\section{HNF-SD-WM-PMP-022, Rev. 0}

\section{F.0 INTRODUCTION}

The overall objectives of the HTI resource plan are to identify the resource requirements for completing the HTI mission and the methods for allocating and controlling resource expenditures. A resource-loaded WBS (Appendix A) will be used as the primary budget-planning tool. Changes and refinements to the resource plan will be coordinated with ongoing budget activities, such as the Internal Review Budget and Multi-Year Program Plan (MYPP) development process.

The objectives of the HTI resource plan are to set forth the following:

- HTI Project WBS

- Cost estimates for 1997 through 2000

- Leverage financing with other programs (technical leveraging with other programs) is discussed in Appendix C

- HTI Project controls for management of the project resources.

The resource plan will be refined as HTI Project definition and planning become more mature.

\section{F.1 HANFORD TANKS INITIATIVE COST/WORK BREAKDOWN STRUCTURE}

The HTI Project summary-level WBS is shown in Appendix A. The work elements of the WBS represent clearly definable and distinctive products that are a composite of the major deliverables from lower levels of that portion of the WBS. The project WBS was developed based on work to be accomplished and has no resemblance to existing organization structures or funding divisions between EM-30 and EM-50.

\section{F.2 HANFORD TANKS INITIATIVE COST ESTIMATE}

The summary-level cost estimate for the HTI Project is shown in Table F-1. The main elements of the cost estimate correspond to the work elements of the WBS. The cost estimate was developed using a bottoms-up approach, assuming the HTI mission is to be accomplished in five years, irrespective of funding source. A bottoms-up approach was utilized to develop the estimate. A more detailed breakdown of the HTI Project cost estimate is given in the resource-loaded WBS and project schedule provided in Appendices A and B, respectively. 
HNF-SD-WM-PMP-022, Rev. 0

Table F-1. Hanford Tanks Initiative Cost Estimate (\$000)

\begin{tabular}{|c|c|c|c|c|c|c|}
\hline Work Element & $\begin{array}{l}\text { FY97 } \\
(000)\end{array}$ & $\begin{array}{l}\text { FY98 } \\
(000)\end{array}$ & $\begin{array}{l}\text { FY99 } \\
(000)\end{array}$ & $\begin{array}{l}\text { FY00 } \\
(000)\end{array}$ & $\begin{array}{l}\text { FY01 } \\
(000)\end{array}$ & Total \\
\hline $\begin{array}{l}\text { Project Management, } \\
\text { Administration and QA }\end{array}$ & 1330 & 1148 & 1225 & 832 & 852 & 5387 \\
\hline Systems Engineering & 366 & 420 & 248 & 254 & 0 & 1288 \\
\hline $\begin{array}{l}\text { End State Performance } \\
\text { Assessment Modeling }\end{array}$ & 148 & 94 & 0 & 0 & 0 & 242 \\
\hline Alternatives Study & 762 & 795 & 0 & 0 & 0 & 1557 \\
\hline NRC Criteria & 0 & 207 & 0 & 0 & 0 & 207 \\
\hline $\begin{array}{l}\text { Closure Basis Strategy and } \\
\text { Integration }\end{array}$ & 1291 & 1106 & 122 & 0 & 0 & 2519 \\
\hline $\begin{array}{l}\text { Retrieval Operations and } \\
\text { Services (In-Tank) }\end{array}$ & 0 & 0 & 0 & 589 & 2155 & 2744 \\
\hline $\begin{array}{l}\text { Characterization Technology } \\
\text { and Deployments }\end{array}$ & 1998 & 1241 & 756 & 0 & 0 & 3995 \\
\hline $\begin{array}{l}\text { Closure Engineering AX- } \\
104\end{array}$ & 110 & 208 & 384 & 127 & 0 & 829 \\
\hline $\begin{array}{l}\text { Heel Process Analytics and } \\
\text { Slurry Monitoring }\end{array}$ & 126 & 0 & 449 & 601 & 0 & 1176 \\
\hline $\begin{array}{l}\text { Retrieval Technology } \\
\text { Acquisition }\end{array}$ & 2946 & 0 & 0 & 0 & 0 & 2946 \\
\hline $\begin{array}{l}\text { Regulatory Compliance } \\
\text { Planning/Permit Preparation } \\
\text { for C-106 and AX-104 }\end{array}$ & 13 & 126 & 65 & 69 & 37 & 310 \\
\hline Safety Documentation & 299 & 214 & 223 & 116 & 146 & 998 \\
\hline Site Upgrades & 0 & 672 & 5308 & 7163 & 0 & 13143 \\
\hline $\begin{array}{l}\text { Field and Laboratory } \\
\text { Sample Analysis }\end{array}$ & 0 & 756 & 609 & 480 & 271 & 2116 \\
\hline $\begin{array}{l}\text { AX-104 Vadose Zone } \\
\text { Contaminant Assessment }\end{array}$ & 734 & 1409 & 527 & 0 & 0 & 2670 \\
\hline Retrieval System Supply & 1266 & 3286 & 3938 & 7588 & 368 & 16446 \\
\hline $\begin{array}{l}\text { Tank Farms Residual Waste } \\
\text { Inventory Assessment }\end{array}$ & 173 & 523 & 101 & 432 & 367 & 1596 \\
\hline Total & 11562 & 12205 & 13995 & 18251 & 4196 & $\$ 60169$ \\
\hline
\end{tabular}




\section{F.3 COST LEVERAGING}

The HTI Project is committed to leveraging investment costs and technical performance data to maximize results per dollar expended. Leveraging for the HTI embodies both waste retrieval and tank closure activities at other sites in the DOE complex, and other programs being conducted at the Hanford Site. The HTI staff are working on the premise that leveraging can work two ways, and just as the HTI will obtain performance data and key information from activities at other sites, the HTI will share with other sites the results of work performed at the Hanford Site. Examples of leveraging with other sites include the following:

- Maintaining an active liaison with the ORNL Gunite Tanks Treatability Test to obtain performance data on characterization, the LDUA and confined-sluicing, and capability of the Houdini remote-control vehicle. The HTI is particularly interested in performance data on the tandem operations of the LDUA and Houdini. Other activities of interest to the HTI include ORNL interfaces with regulators and stakeholders, and performance assessment methods and results. Data received to date have been very helpful in furthering the HTI Project planning

- Maintaining the working liaison with the SRS work, specifically for the proposed closure of tank $19 \mathrm{~F}$ and the subsequent closure of tanks 17 through 20 , and the density-gradient and other retrieval work in tank $41 \mathrm{H}$. Waste retrieval from tank $41 \mathrm{H}$ will produce performance data of interest to the HTI on salt cake retrieval. As is the case for ORNL treatability tests, active interchanges with the regulatory and stakeholder communities at the SRS, and SRS technical counterparts on performance assessment methods and calculations will provide information of value to the Hanford Site

- The interface with INEL encompasses both the sampling and closure of the "V" tanks, and sampling and heel removal operations in the HLW tanks. Results of regulatory and stakeholder interface activities, and the performance assessment method will be tracked. Depending on the timing and scope of site activities, there also may be active discussions with both Fernald and West Valley.

- A DOE complex-wide agreement is likely on the nature of the interface with the NRC. Hence, there will be a cooperative effort on obtaining an NRC determination on non-HLW for post-retrieval residual waste. Although there are existing lines of communications with the other sites on cooperative efforts for specific closure and retrieval activities, the DOE complex has yet to decide on a common approach to the NRC.

- Performance data from the HTI and from other sites within the DOE complex will provide a compendium of information useful to the bidders for Phase II privatization at the Hanford Site and thereby reduce the contingencies for uncertainty in their proposals. The performance data and results of regulatory 
and stakeholder activities will greatly benefit those responsible for developing the specification for Phase II.

As indicated above, leveraging encompasses both offsite and onsite programs and/or projects. Examples of leveraging activities with other Hanford Site programs include the following:

- Using the LDUA and the available suite of tools, subsystems, and trained operations staff to characterize waste in tanks 241-AX-104 and 241-C-106. The LDUA stand-alone video system has already been used to obtain additional data on residual waste in tank 241-AX-104

- Using the new cone penetrometer to be delivered to the Hanford Site in conjunction with ERT being tested by the ISSTRS program

- Using the TWRS vadose zone characterization program to determine the subsurface soil characteristics and distribution of contaminants and radionuclides for the AX tank farm. (Although this information will be site-specific, the process used to define data needs and to acquire the data are transferable)

- Using newly installed analytical capability in the 222-S Laboratory, such as LA/MS, for more rapid, complete, and cost-effective analysis

- Project W-320, past-practice sluicing of tank 241-C-106 will provide considerable infrastructure, and will thereby avoid additional HTI costs

- Using the TMS to evaluate the volume of residual waste remaining in tank 241-AX-104

- If sufficient residual waste is present, using a cone penetrometer to characterize residual waste in tank $241-\mathrm{C}-106$ after sluicing is completed.

\section{F.4 ASSUMPTIONS AND LIMITATIONS ASSOCIATED WITH THE COST ESTIMATE}

- The cost estimate in this report is best classified as a definitive estimate at this stage of project planning.

- Some project approaches and TFA technology contributions may change, resulting in changes for the associated costs.

- Workshops with stakeholders and regulators on retrieval performance objectives could result in either the addition or deletion of currently planned scope. 
- The project team is working to ensure the HTI planning is incorporated into the MYPPs for both TWRS and the TFA. This consideration should improve linkage with related programs and help maximize leveraging.

\section{F.5 PROJECT SCHEDULES}

The summary schedule for the HTI Project is shown in Figure F-1, with additional details shown in Appendix B. The activities in these schedules were used to develop bottom-up cost estimates. The major schedule elements correspond to the level-two elements of the WBS; each work element of the WBS has a specific schedule.

The schedules show a smooth transition of TFA and ACTR activities into the HTI Project. Given the successful interaction between all parties during the preliminary project definition, this type of transition has been shown to be achievable. The one major interface the HTI Project cannot control is the timing for completion of past-practice sluicing. For purposes of this plan, it was assumed that Project W-320 and associated post-project activities will be accomplished per current project schedules.

\section{F.5.1 Project Network}

The network representation of the detailed schedules in Appendix B is provided in Appendix C. This network was provided to allow the project team to identify and utilize the relationships and sequences of project activities.

\section{F.5.2 Assumptions and Limitations}

- All leveraging opportunities with other programs at the Hanford Site have yet to be identified. Hence, some additional activities may be shown as other opportunities are identified and the schedule is updated.

- The schedule assumes that there will be no adverse impact as the TWRS FSAR is finalized, and that preparation of safety documentation will be facilitated by the existence of a new BIO.

- HTI Project workshops with stakeholders and regulators could result in either the addition or deletion of currently planned scope.

- The schedule basis assumes that adequate funding will be available at the first of the fiscal year, with no constraints such as a continuing-resolution budget. 
HNF-SD-WM-PMP-022, Rev. 0 .

Figure F-1. Hanford Tanks Initiative Project Summary Schedule.

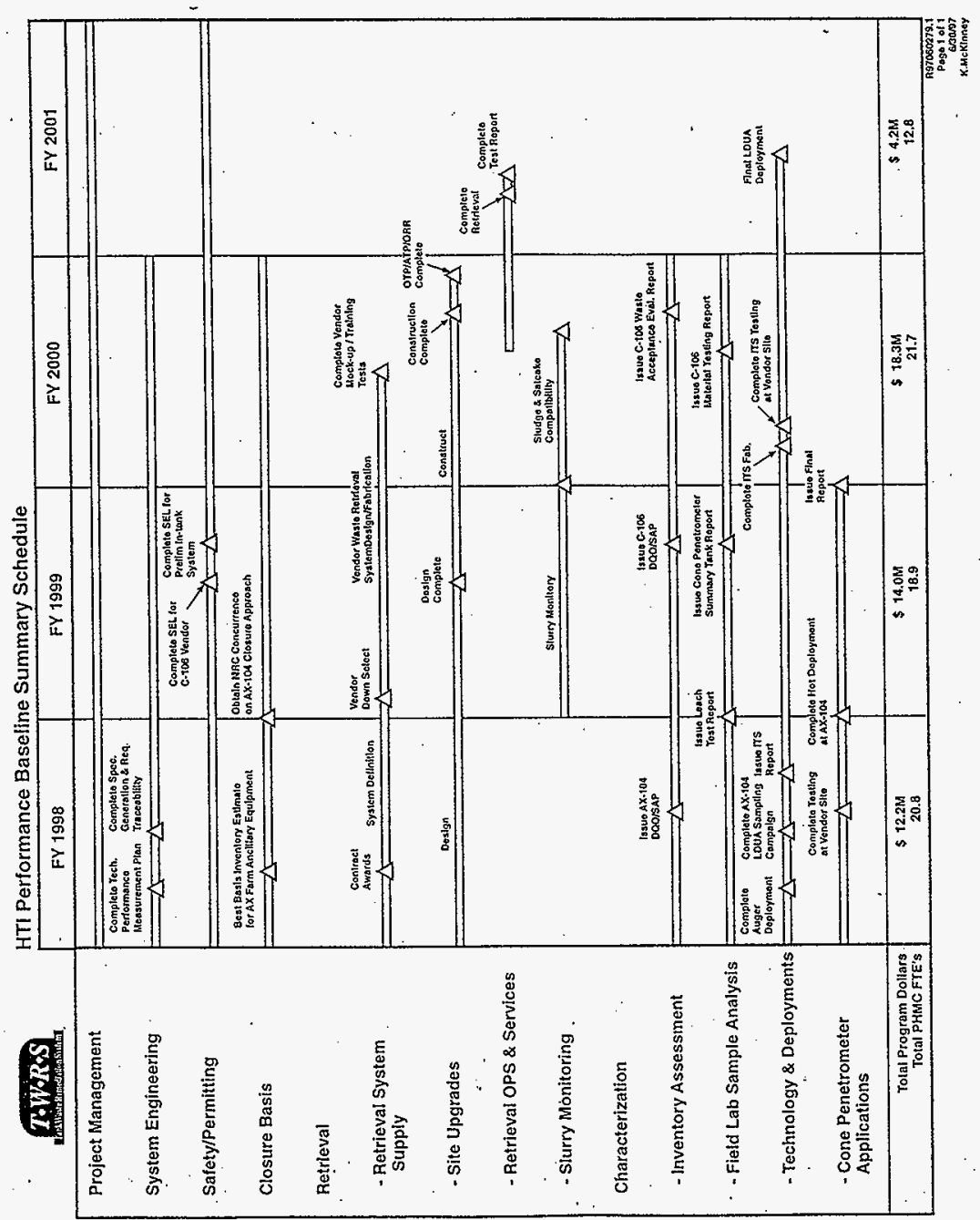




\section{F.6 PROJECT CONTROLS}

This section presents the spectrum of project controls, from financial to communications, including the outline of activities and responsibilities of the Change Control Board.

\section{F.6.1 Financial/Schedule Controls and Work Breakdown Structure}

The project financial architecture is based on the WBS shown in Appendix A. The WBS will be used as basis of all financial and schedule reporting and the release of authorized funding to perform project activities. Once the first three or four levels of the WBS have been approved by the project manager and incorporated into the project plan, the scope statements and activities in the approved levels of the WBS may not be changed without the specific authorization of the project manager. The scope of the project, which is reflected in the WBS, will be derived from the HTI mission statement and HTI functions and requirements.

In general, a rolling wave or moving window approach will be used to develop the lower levels of the WBS. This means the WBS will be more completely developed at the lower levels of the WBS for near-term work (within 1 to 2 years) than for activities to be performed in the last two years of the project. This approach was selected because the specific scope of some activities for lower levels of the WBS that are to be performed later in the project life will depend on decisions to be made during the first two years. Several key decisions affecting the scope of specific parts of the work are not within the control of the project. An example of such a decision is the stakeholder- and regulatory agencyapproved criteria for interim retrieval goals.

All scope, schedule, and resource planning for accomplishing the scope of work at the lowest level of the WBS will be accomplished based on agreed-to measures of progress. This type of planning will facilitate utilization of earned value to monitor and measure project progress against the project plan (Appendix J). Earned value analysis (budgeted cost of work performed [BCWP], budgeted cost of work scheduled [BCWS], and actual cost of work performed [ACWP]) will be the basis of all project scope, financial, resource, and schedule reporting. In general, the workscope will be defined down to the fifth level of the WBS. In some cases, where it make sense to avoid artificial divisions of scope, work packages may be defined to a higher level. Examples of project-controlled work at a higher level include work to be performed by vendors, where the vendor would be responsible for development of additional levels of the WBS.

Planning for specific work packages will be based on, and traceable to, the scope statement for that work; the latter will be provided in the WBS dictionary. All scope statements for work packages in the WBS dictionary will be approved by both the responsible HTI manager and the project manager. Planning for work packages will include: a statement of the scope, goals and objectives; a succinct narrative of the technical approach to accomplish the scope; all interim performance measures; a network of all work package 
activities showing constraints and precedents; a Gantt chart; a spending (cash flow) curve; and a clear identification of risks that will be managed to accomplish the scope of the work package. Brevity and clarity will be valued over volume in the preparation of the work package plan.

Planning will be based on man hours, burdened labor dollars and material costs. The lead individual responsible for completion of the work will be accountable for man-hour expenditures and material costs. Changes that affect burdened labor dollars will be negotiated by the project manager; hence, it will be the responsibility of the individual performing the work to promptly notify the responsible project lead and the project manager of pending or actual changes in the burdened rate. The plan to accomplish the workscope described in the WBS will be approved by both the responsible project lead and the project manager before authorizing the funding for a specific work package.

Monthly reporting for work packages will include a narrative of actual progress against planned progress, with sufficient detail that other project participants can utilize the information. The earned value will be determined and cost and schedule variances calculated (cost variance $=\mathrm{BCWP}-\mathrm{ACWP}$, and schedule variance $=\mathrm{BCWP}-\mathrm{BCWS}$ ), with all values reported in dollars. Monthly and cumulative variances larger than $+10 \%$ and $-15 \%$ at the work package level will require a variance explanation and recovery plan. In addition, the work package will provide a trend-analyses report by showing a continuous plot of the cost and schedule performance index (CPI = BCWP/ACWP and SPI $=\mathrm{BCWP} / \mathrm{BCWS})$.

The report will identify any emerging problems and the proposed resolutions. The report will also identify planned key activities for the next reporting period. The project manager reserves the right to directly intervene, given a continued unfavorable CPI and/or SPI. This intervention can include the option to reassign the balance of the work package to another performer. Re-planning or re-baselining the plan for the work package may not be performed during a fiscal year without specific authorization from both the responsible HTI manager and the project manager.

The project manager will maintain a management reserve each fiscal year, and may distribute up to $10 \%$ of the project annual budget in a single action with his/her own authority. The management reserve is intended to cover unforeseen problems, and will not be used to recover from poor planning. Individual changes larger than $10 \%$ of the annual project budget and cumulative changes larger than $15 \%$ of the project budget will also require approval of the change control board. All withdrawals from the management reserve will be recorded in the change control log, which will be maintained by the project manager's designee. A key change control feature will be to promptly capture budget underruns. Some tasks will be accomplished without consuming all of the planned resources. These budget underruns will be withdrawn by the project manager and added to the management reserve.

The change control board will have three permanent members: the HTI Project manager (CCB chairman); manager of the DOE-RL Waste Disposal Division and the DOE-RL Coordinator of the TFA. At the discretion of the board members, additional 
members may be added as necessary, either as permanent members or to provide special expertise for specific situations.

The project manager will review the project schedule and designate key milestones. Once designated, these milestone and the schedule for critical support activities may not be changed without approval from the project manager. Progress against these key milestones and support activities will be reported each month at the work package and task levels, using the variance criteria previously described. The log of key milestones will be maintained by the project manager or the project manager's designee. Schedule Performance Indexes will be summarized for key milestones and support activities at all reporting levels in the WBS, but lower-level SPI data will be attached to the higher-level monthly report so that potentially significant variances at lower levels are not lost in the summarization process.

\section{F.6.2 Commitment Control}

A commitment is an agreement or request for which an authorized HTI representative has accepted or been assigned responsibility that requires action or response.

A computerized record of HTI commitments will be published weekly, listing and statusing updates of commitments between the HTI team and DOE, vendors or other parts of the PHMC organization. The commitment control list (CCL) will be supplemented with additional key milestone and supporting event listings. These will be reviewed weekly, along with the commitments.

The project manager will designate a person responsible for commitment control. The commitment control designee will review all incoming and outgoing formal correspondence for new commitments and satisfaction of commitments; assign commitment control numbers to each new commitment; enter the commitment description, due date, responsible project lead, and response letter number and date in the CCL; and furnish an updated listing of commitments to HTI managers each Tuesday. The managers will review the updated listing and advise the commitment control designee of corrections or additions. The HTI will designate responsibility to a single individual to see that the commitment is met on or before the due date and notify the commitment control designee of the completion.

\section{F.6.3 Periodic Independent Risk Assessments}

Periodically, at the discretion and direction of the project manager, independent probabilistic risk assessments may be conducted to supplement the day-to-day HTI Risk Management practices. Because these assessments focus on future events, the uncertainties of the participants and the state of information, a Bayesian or subjective approach will be used. Decision trees reflecting the project approach, the subjective probability of success or failure, and the logical alternate courses if failure occurs will be developed to quantify the overall probability of success of any sub-element of the HTI Project. This subjective assessment will be conducted by a series of interviews between HTI Project team members and persons skilled in conducting probabilistic evaluations, project management methods, 
decision analyses, and other technical skills as appropriate. Materials to support the interviews will be current project plans and schedules; no special information will be needed for preparation. Information and data from these evaluations will be used by the HTI Project manager and HTI managers to refine HTI risk mitigation approaches.

\section{F.6.4 Project Communications}

All formal correspondence between HTI team members and persons outside of the HTI Project will have an HTI identification number. The numbering system will be developed at a later date and described in an appendix of the project plan. A person designated by the project manager will be responsible for assigning the number and maintaining an overall project correspondence file. The project correspondence file will be accessible to all members of the project team. When HTI team membership is further defined, standard distribution lists will be developed.

All significant telephone conversations with people outside of the HTI Project team will be documented using a standard teleconference record form. These forms will be completed by HTI team members and distributed to the other participant(s) to confirm understandings and agreements. Differences, if any, will be promptly resolved and a revision issued.

All project-related travel or meeting attendance will be documented by the timely preparation and submission of a report. Standard distribution lists will be used to disseminate information resulting from the travel. If persons on travel enter into an understanding that may affect the HTI Project scope, schedule, cost or performance, the traveler will document those understandings before returning home. The draft understanding will be faxed back to the HTI Project manager or his designee for review, before the HTI representative leaves the meeting. Impacts will be reconciled before completing the travel.

As the HTI Project progresses, additional HTI guidelines will be developed for control of data transmittals, changes, and interfaces, as necessary.

Communications with Ecology will be coordinated through the HTI Project manager or his designee. Communications will reflect all existing agreements, understandings and MOUs between the HTI Project and Ecology, in the overall endeavor to build a relationship of trust and cooperation. Additional guidelines will be issued by the HTI Project manager, as necessary.

\section{F.6.5 Project Approvals}

DOE approval is necessary for overall policy and project scope, total project cost and top-level project schedules. All other changes to the HTI Project, except for those changes reserved for the Change Control Board approval, will be approved by the HTI Project manager and/or his designee. All drawings, specifications and topical reports will be approved by the HTT Project manager or his designee before release. 


\section{F.6.6 Project Meetings}

Formal staff meetings between the HTI Project manager and the other HTI managers will be held once per week, as scheduled by the project manager. The purpose of these meetings will be to review project progress, review and status commitments, and discuss other agenda items as set by the HTI Project manager. Other HTI meetings will be scheduled and conducted as necessary to support project progress and needed information exchanges.

Monthly project reviews will be conducted with the DOE-RL Manager of Waste Disposal (or his designee) and the DOE-RL Coordinator of the TFA (or his designee). The purpose of these meetings will be to review project status, emerging problems or issues, and near-term plans of project participants.

Quarterly presentations will be made to the STCG Tanks Subgroup and the appropriate $\mathrm{HAB}$ subcommittee to keep those key participants informed. Presentations will focus on progress, emerging issues where stakeholder interests are likely to be involved, and planned progress for the next reporting period. Presentations will be targeted to last no more than 30 minutes. Copies of the viewgraphs will be made available to participants and for incorporation into the meeting minutes.

The project manager may periodically conduct special review meetings for specific parts of the project. The frequency and content of such review meetings will be determined by the project manager.

\section{F.6.7 Project Reports}

HTI lead personnel will provide the HTI Project manager weekly progress reports each Wednesday in a brief narrative format (format to be established by the HTI Project manager).

HTI lead personnel will submit a narrative monthly report to the HTI Project manager on the 25th of each month. Items to be included in the report are described in Section 1.2.7.1. Per the instructions in that section, supporting CPI and SPI data will be provided as backup material. These reports will be consolidated, as needed, to meet the requirement of the site management system (SMS) and project tracking system (PTS) reporting requirements. The project manager will designate the person responsible for the consolidation. 
HNF-SD-WM-PMP-022, Rev. 0

This page intentionally left blank. 
HNF-SD-WM-PMP-022, Rev. 0

APPENDIX G

BUSINESS AND FINANCIAL PLANS

G-i 
HNF-SD-WM-PMP-022, Rev. 0

This page intentionally left blank. 


\section{G.0 INTRODUCTION}

The HTI financial and technical partnership requires that two separate funding sources and administrative processes within the DOE EM organization be integrated. For planning purposes, the HTI has been assumed to establish and manage a single performance baseline to administer financial and work scope controls. The intent is to optimize planning and reporting efficiencies, while providing adequate visibility and accountability for each partner's independent reporting system.

\section{G.1 SCOPE}

This plan summarizes the procedure for how the HTI Project will conduct business and measure performance against a single EM-50 planning baseline.

\section{G.2 WORK BREAKDOWN STRUCTURE}

The HTI Project will be identified as cost accounts within the Waste Retrieval Program Element (ADS 1210-0 and 1.1.1.3.1) of the SST project (1.1.1.3.1:1). Two cost accounts will be established for this project; one will be for HTI EM-30; the other will be for HTI EM-50. A single cost account for HTI will be established to provide all cost and schedule control information (i.e., information on tasks, milestones [Milestone Description Sheets], resources, WBS Dictionary Sheets, Baseline Narrative, Baseline Management, etc.), and to provide for project cost accumulation. Monthly costs will be prorated to the EM-30 and EM-50 cost accounts in direct proportion to each partner's contribution (annual adjustments in the proration will be made as needed to reflect current fiscal year contributions).

\section{G.3 ACTIVITY DATA SHEET/TECHNICAL TASK PLAN (TTP)}

The HTI funding basis for EM-30 will be ADS 1210-0. The funding request will be for the total EM-30 life cycle. The ADS will detail the entire scope of the HTI in accordance with the planning schedule. The HTI funding basis for EM-50 will be TTP RL07WT61, funded through the TFA. The TTP funding request will be for the total EM-50 life cycle. 


\section{G.4 PERFORMANCE REPORTING}

Reporting for DOE-RL HTI will follow the standard PTS format.

The PTS reporting will be from both EM-30 and EM-50 perspectives:

- $\quad$ Each PTS report will be loaded with monthly budget data derived from the predetermined percentage allocation specified by the budget cost and work schedule planning. In addition, the status of work and completion of project milestones will be included in the PTS report for EM-30 and EM-50.

- Financial status will be reported in terms of the percentage allocated to each of the two cost accounts, based on the proportion of funding being provided to the HTI Project from the two sources. The basic process involves collecting actual costs in the HTI Project cost account, prorating the actual costs, and performing a funds transfer to ensure that EM-30 and EM-50 cost accounts contain the appropriate actual costs. The BCWP will be manually adjusted in the PTS using the same basis as was used for the actual funds transfer calculation.

- The narrative of accomplishments, issues, corrective actions, milestone status and variances will be written at the HTI Project level (i.e., not specifically tied to the cost distribution between the two accounts). By this means, EM-30 and EM-50 will be informed of the total progress toward completion of the HTI Project mission.

The project status will be communicated by using established program element and project level reporting formats. Specifically, the HTI will be reported as part of the Tank Waste Retrieval Program, within the SST project, and as part of the TFA program.

The HTI will report monthly to DOE-RL TWRS as part of the monthly Waste Retrieval/Waste Disposal management meeting. This report will be in terms of progress of the HTI Project, with no specific discussion as what EM-50 or EM-30 have completed. In addition, the HTI will provide monthly project presentations to combined DOE-HQ EM30 and EM-50 staffs.

Points of contact within FDH will be provided to answer DOE-HQ staff questions. Likewise, the DOE-RL anticipates that DOE-HQ will provide points of contact from their organization.

\section{G.5 PLANNING}

All HTI planning will be done in accordance with EM-30 planning guidelines. A taskoriented MYPP will be developed that describes the strategy and mission of the HTI Project. The TTP will be developed to reflect life cycle plans and cost, and will be consistent with the MYPP. The MYPP will be developed and/or updated annually and will include: 
- Life-cycle Financial Requirements--This information will be presented in terms of yearly expenditures required and tasks to be accomplished. These requirements will exceed the planning guidance for EM-30; however, EM-50 has been assumed to provide the agreed-upon funding, and the amounts required will be specified by year. The sum of EM-30 plus EM-50 funding will equal the amount requested by the MYPP.

- Baseline Narrative--This report will be prepared to outline the project mission, technical objectives, major accomplishments, planning assumptions, principal interfaces, major deliverables, project risks, etc.

- Work Breakdown Structure Dictionary Sheets--These data sheets will outline the goals and objectives, deliverables, statements of work, and budget.

- Milestone Description Sheets--These data sheets will be prepared for the life-cycle of the HTI. The milestones will be described at different levels of detail (e.g, Tri-Party Agreement, DOE-HQ, DOE-RL, Key and others) based on negotiations with the partners of HTI. These data sheets will describe the work to be performed to complete a specified milestone and the work acceptance criteria.

- Resource Loaded Schedule - This schedule will be logic driven, resource loaded, and task oriented. Details will be provided on the specific tasks and milestones to be accomplished, and on the specific resources to be utilized. This schedule will be reviewed with the partners and will become the project performance baseline.

Planning for EM-50 will involve repackaging of the MYPP into a Technical Task Package format.

\section{G.6 FUNDING}

EM-30 funding will be provided to FDH in the financial plan. This funding will be placed in the HTI EM-30 cost account. Funding provided from EM-50 to DOE-RL will be issued to Fluor Daniel using a Request for Services. The EM-50 funding will be assigned to the HTI EM-50 cost account. Should continuing-resolution funding occur during the life of the project, the HTI will assume that funding will eventually be provided to accomplish the mission. Accordingly, the PHMC HTI Project manager will proceed with implementing the MYPP to accomplish the mission on schedule. Project funding will be managed by the PHMC HTI Project manager.

\section{G.7 CHANGE CONTROL}

All changes to the performance baseline will be documented via change request, using EM-30 procedures and change control definitions. All changes to the baseline in excess of 
\$250k will be coordinated with the RL HTI Project manager and RL TPO project manager. After approval of baseline changes, copies of baseline documentation will be distributed to custodians of the MYPP and TTP baseline. The project office will maintain configuration management of baseline documentation.

\section{G.8 RESPONSIBILITIES}

The Contractor's HTI Project manager at the Hanford Site will have the responsibility and authority to carry out the work of this project.

Prior to any budget recision or reduction, the project manager and the partners will consult on resulting actions, if the reductions are initiated at DOE-HQ. 
HNF-SD-WM-PMP-022, Rev. 0

APPENDIX $\mathbf{H}$

SCHEDULE CONTROL, COST CONTROL, AND REPORTING 
HNF-SD-WM-PMP-022, Rev. 0

This page intentionally left blank. 


\section{H.0 INTRODUCTION}

Schedules are an aspect of work plans that focuses on time and resources. This appendix describes the types of schedules used by PHMC to prepare, document, integrate, and report progress towards achieving objectives of the planned scope of work.

\section{H.1 DEFINITIONS}

\section{H.1.1 Milestone}

A milestone is an event identified by management or the $\mathrm{DOE}$ to represent the achievement objectives which are critical control points used to monitor and direct progress toward accomplishing the approved work scope.

H.1.1.1 Tri-Party Agreement Milestone. Tri-Party Agreement Milestones established by the Hanford Federal Facility Agreement and Consent Order (DOE, EPA, and Ecology) are milestones determined to be critical to the success of the mission to remediate the Hanford Site and selected to be monitored and controlled in accordance with the provisions of the Tri-Party Agreement.

H.1.1.2 DOE-HQ Major Milestone. A U.S. Department of Energy-Headquarters (DOE-HQ) major milestone is a milestone that has been determined to be critical to the success of a program or project and has been selected for monitoring and control by the DOE-HQ.

\section{H.1.1.3 DOE-RL Major Milestone}

A DOE-RL major milestone is a milestone that has been determined to be critical in achieving DOE-HQ major milestones and has been selected by the DOE-RL for monitoring and control.

H.1.1.4 Key Milestone. A key milestone is an event selected by the PHMC program or project management for monitoring and control that has been determined to be necessary to ensure achievement of major milestones. 


\section{H.1.2 Schedule Hierarchy}

Several levels of schedule details are required to effectively portray the scope of work. Specific elements of work must be traceable from one level to another. Schedules will be developed that incorporate elements of the WBS to provide traceability and integration of the work elements. Higher-level schedules show less detail and cover a longer span of time; lower-level schedules show greater detail for a shorter duration. For those work elements whose value is smaller than the line item value, the number of schedule levels may be appropriately reduced.

H.1.2.1 Integrated Milestone Schedule (Level 0). Development of the Integrated Project Milestone Schedule (IPMS) is the responsibility of the DOE-RL; however, this responsibility may be delegated to the PHMC. The Level 0 schedule reflects major milestones that support assigned PHMC mission(s). Lower-level schedule commitments will be traceable to the major milestone of which they are a part. The Level 0 schedule results from strategic and technical plans, and incorporates the impacts of funding and resource comments. The Level 0 schedule will be reflected, as appropriate, in each program or project plan, in other long-range planning documents, and on the activity data sheet (ADS). This schedule will depict the life-span of the mission(s) and related program or project. The Level 0 schedule is approved by the DOE-RL.

H.1.2.2 Master Summary Schedule (Level 1). The master schedule is the top-level schedule for programs and/or projects. It contains all Tri-Party Agreement, DOE-HQ, and DOE-RL milestone commitments. It portrays the scope of work at the program or project level. Each Level I milestone depicts work at the WBS end-function level. Level 1 milestones extend for the life of the program or project. For projects, the Level I schedule is approved by the project manager and the appropriate program manager(s). For programs, the Level I schedule is approved by the appropriate program manager and reporting manager(s).

H.1.2.3 Master Operating Schedule (Level II). The master operating schedule includes all Tri-Party Agreement, DOE-HQ, DOE-RL, and key milestones. Expense-funded and/or capital-funded work may be included on a single schedule, or specific WBS elements may require a separate schedule depending on the work complexity. Generally each activity represents a summary of the work at the WBS cost account level. For projects, the Level II schedule is approved by the project manager and reporting manager(s), as appropriate. For programs, the Level II schedule is approved by the appropriate responsible manager and reporting manager(s).

H.1.2.4 Cost Account Schedule (Level Im). Cost account schedules include all Tri-Party Agreement, DOE-HQ, DOE-RL, key, and other milestones. They depict task package activities in logical sequence and show interrelationships and dependencies within and between cost accounts. They show when and how the task package activities culminate to meet major and key milestones. The cost account schedule is approved by the activity manager and cost account manager (CAM) in conjunction with the performing organizations. 
H.1.2.5 Working Schedule (Level IV). The optional working schedule depicts the work scope for the program or project in CAP detail (work packages/task packages). It provides a firm basis for calculating performance measurement. This is generally the lowest level program or project schedule within PHMC and is traceable to the Level Ill schedule. The Level IV schedule is approved by the CAM in conjunction with the performing organizations.

\section{H.2 RESPONSIBILITIES}

\section{H.2.1 Program and Project Managers}

The program or project managers define program or project requirements in approved program or project plans, approve the Level I and Level II schedules, and monitor and control major and key milestones.

\section{H.2.2 Activity Manager}

The activity manager is responsible for incorporating the major and key milestones into the appropriate cost account authorization (CAA) and for verifying that the milestones are integrated into the appropriate cost account plan (CAP).

The activity manager will ensure that interrelationships between task packages have been identified and incorporated in each CAP, verifying that the logical flow of work is reflected in the CAPS.

\section{H.2.3 Cost Account Managers}

The CAM will coordinate and secure approval of the task package milestones and schedule dates from the activity manager responsible for the applicable schedules. The CAM is responsible for reporting progress against the Level Ill schedule and for explaining variances that exceed established thresholds.

\section{H.2.4 Program and Project Control Organizations}

The program and project control organizations are responsible for the preparation and maintenance of program and project schedules, including incorporation of documented, approved changes to the schedule baseline, coordination of approvals, and maintenance of schedule traceability. These groups also prepare and maintain the milestone control logs and milestone description forms. 
The assigned scheduling representatives prepare and maintain the Level I through IV schedules and also prepare and maintain special schedules. The schedulers also incorporate activity status and approved changes and provide monthly and quarterly reports on schedule progress.

\section{H.3 REQUIREMENTS}

\section{H.3.1 Schedule Status}

Schedule status is updated on a monthly basis to measure performance and to provide management with reported information. Updating the status involves ascertaining the amount of progress for all work in process and determining whether or not an event or milestone has been completed. The actual status is recorded and graphically depicted on all appropriate schedules. Status information is calculated for each cost account of the WBS using the appropriate earned-value method. Work progress information is initially gathered by the CAM from the managers or direct contributors who are most directly responsible for scheduled work in progress. The status of schedules used for performance measurement and reporting is updated on a monthly basis, concurrent with cost accumulation and reporting.

The status of schedules used to manage complex or critical work elements is updated as appropriate for management needs. The schedule must always portray an up-to-date, approved baseline work plan.

Schedule status is reported to the DOE-RL in the PHMC Monthly Report or Project Manager Progress Report. The milestones in these reports specifically address major milestones scheduled to be completed within the current fiscal year. Schedule status in these reports must come from the approved baseline schedule.

\section{H.3.2 Schedule Analysis}

Schedule variance, as reflected in the cost performance reports, is the difference between the value of the work actually performed during a given period and the value of the work scheduled to be performed (BCWP minus BCWS) for that same period. Comparison of $\mathrm{BCWS}$ to $\mathrm{BCWP}$ indicates deviation to plan and provides a valuable indication of schedule status in terms of dollars' worth of work accomplished. It may not, in all cases, clearly indicate whether or not scheduled milestones are being met because some work may have been performed out of sequence or ahead of schedule.

Schedule analysis is a significant part of the variance analysis cycle and begins after the monthly status update has been completed and has been reflected on performance reports upward through all levels of the WBS hierarchy. Variances occur where work progress for any cost account or activity is not following the baseline plan as to time or logic. Variances are analyzed for impact and for work-around possibilities. Depending on current conditions 
existing in other related areas of the work plan, a simple impact at the task level could be lessened or amplified at higher levels of the schedule.

\section{H.3.3 Schedule Forecast}

As work progresses, forecast dates that differ from scheduled milestone completion dates are expected, and these differences generate variances that are a key element of performance measurement. Those variances that exceed established thresholds are analyzed and reported to management.

\section{H.3.4 Schedule Revisions and Changes}

H.3.4.1 Revisions. Revisions to the schedule emanate from the following sources:

- When the status of schedules or the schedule variance of the performance measurement baseline indicate that accomplishment is not tracking to the time-phased plan and has exceeded established thresholds, appropriate analysis is required to develop an acceptable recovery plan. Revisions to baseline schedules may only be allowed after a change request has been approved. It should be noted that schedules are not "rebaselined" to remove a behind schedule status.

- Revisions necessitated by the limitation of planning insight into the future. This usually involves assimilation of more details into the lower-level schedules and may involve logic and duration changes to reflect a current work plan.

- Revisions resulting from customer, program, or project management redirection or change.

- Changes in resource availability (funding or staff).

\section{H.3.4.2 Change Control}

Changes associated with Tri-Party Agreement and major milestones are processed as Class I changes on a change request initiated by PHMC. If requested changes impact major milestones, work scope changes from one end function to another, or changes in contractual agreements affecting workscope, customer approval is required prior to incorporation. In summary, Level I schedules requiring change are approved by the DOE-RL.

- Changes associated with key milestones will be processed as a Class II change on a change request. If the change impacts any major milestones, it will be classified as a Class I change and be transmitted to DOE-RL for approval prior to incorporation. 
- All changes to scheduled milestones will be developed, approved, and implemented in accordance with the affected program or project change process before the next reporting period.

\section{H.4 PROCEDURE}

This procedure is presented in two parts. Part I is a flow chart summarizing the procedure, and Part 2 is a table explaining the actions and responsibilities to implement the procedure. 
PART 1 FLOW CHART FOR SCHEDULE DEVELOPMENT.

\begin{tabular}{|l|l|}
\hline PM & $\begin{array}{l}\text { Provide guidance for } \\
\text { development of the } \\
\text { Level I schedule }\end{array}$ \\
\hline
\end{tabular}

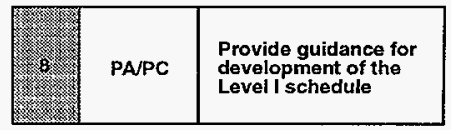

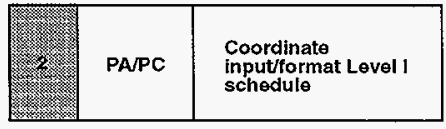

\begin{tabular}{|l|l|}
\hline S. & $\begin{array}{l}\text { Analyze/evaluate and } \\
\text { approve baseline } \\
\text { (Level ll and III) } \\
\text { schedules }\end{array}$ \\
\hline
\end{tabular}

\begin{tabular}{|l|l|}
\hline 1 & $\begin{array}{l}\text { Review, approve and } \\
\text { obtain DOE-RL } \\
\text { approval of the Level 1 } \\
\text { schedule }\end{array}$ \\
\hline
\end{tabular}

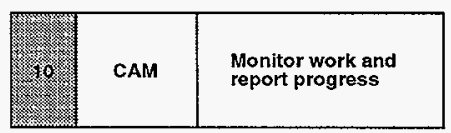

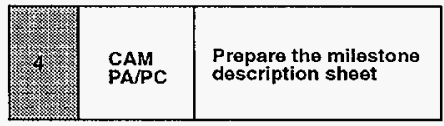

\begin{tabular}{|l|l|}
\hline PA/PC & $\begin{array}{l}\text { Maintain schedules in } \\
\text { current status }\end{array}$ \\
\hline
\end{tabular}

\begin{tabular}{|l|l|l|}
\hline CAM & $\begin{array}{l}\text { Prepare milestone } \\
\text { control log }\end{array}$ \\
\hline
\end{tabular}

\begin{tabular}{|l|l|}
\hline PAPC & $\begin{array}{l}\text { Prepare change } \\
\text { requests for changes to } \\
\text { schedule baselines }\end{array}$ \\
\hline
\end{tabular}

\begin{tabular}{|l|l|}
\hline 19: & $\begin{array}{l}\text { Incorporate major/key } \\
\text { milestones into } \\
\text { CAAs/CAPs }\end{array}$ \\
\hline
\end{tabular}

\begin{tabular}{|c|c|c|}
\hline 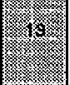 & PAPC & $\begin{array}{l}\text { Incorporate approved } \\
\text { changes }\end{array}$ \\
\hline
\end{tabular}

\begin{tabular}{|c|c|c|}
\hline${ }^{x}{ }^{x}{ }^{x}{ }^{2}$ & PAVPC & $\begin{array}{l}\text { Develop a Level II } \\
\text { schedule }\end{array}$ \\
\hline
\end{tabular}

Legend:
AM Activity Manager
CAA cost account authorization
CAP cost account plan
CAM Cost account manager
PA Program administration
PC program/project control
PM project manager

H97070051.2 
PART 2 PROCEDURE FOR PROGRAMS/PROJECTS.

\begin{tabular}{|c|c|c|}
\hline \multicolumn{2}{|r|}{ Responsibility } & Action \\
\hline 1. & Program Project Manager & $\begin{array}{l}\text { Provide guidance for development of the Level I schedule. } \\
\text { These schedules require input from activity managers, cost account } \\
\text { managers, project control organizations, other major project participants, } \\
\text { and performing organization managers. }\end{array}$ \\
\hline 2. & $\begin{array}{l}\text { Program Administration } \\
\text { Program/Project Control }\end{array}$ & Coordinate the input and format Level I schedule. \\
\hline 3. & Program/Project Manager & $\begin{array}{l}\text { Review, approve, and obtain DOE-RL approval of the Level I } \\
\text { schedule. }\end{array}$ \\
\hline 4. & $\begin{array}{l}\text { Cost Account Manager } \\
\text { Program Administration } \\
\text { Program/Project Control }\end{array}$ & $\begin{array}{l}\text { Prepare the milestone description sheet. The milestone description sheets } \\
\text { contain the criteria for final production of a milestone and are the } \\
\text { agreement between the customer and the contractor for major milestones. } \\
\text { Milestone description sheets are required on all major milestones. For } \\
\text { MSA projects, milestone description sheets are also required on key } \\
\text { milestones. } \\
\text { A sample milestone description sheet and instructions are included as } \\
\text { Appendix A of this procedure. }\end{array}$ \\
\hline 5. & $\begin{array}{l}\text { Cost Account Manager } \\
\text { Program Administration } \\
\text { Program/Project Control }\end{array}$ & $\begin{array}{l}\text { Prepare the milestone control log. An example of the log and } \\
\text { instructions for completion are included as Appendix B of this procedure. } \\
\text { As a minimum, the milestone control log records original completion dates, } \\
\text { any revisions to those dates, and the actual completion dates. }\end{array}$ \\
\hline 6. & Activity Manager & $\begin{array}{l}\text { Incorporate major and key milestones into CAAs/CAPs. Compare the } \\
\text { CAAs with the master operating schedule and the master schedule to ensure } \\
\text { that all major and key milestones are identified. }\end{array}$ \\
\hline 7. & $\begin{array}{l}\text { Program Administration } \\
\text { Program/Project Control }\end{array}$ & $\begin{array}{l}\text { Develop the Level II schedule. Depending on the complexity of the work } \\
\text { and requirements of management, all contract work breakdown structure } \\
\text { level elements may be included on a single schedule, or specific elements } \\
\text { may require separate schedules. The schedule includes all intermediate } \\
\text { milestones and events necessary to complete the scope of work and provide } \\
\text { traceability in the schedule hierarchy. }\end{array}$ \\
\hline 8. & $\begin{array}{l}\text { Program Administration } \\
\text { Program/Project Control }\end{array}$ & Prepare Level III schedules. \\
\hline 9. & Program/Project Manager & Analyze, evaluate and approve baseline schedule. \\
\hline 10. & Cost Account Managers & $\begin{array}{l}\text { Monitor work and report progress towards completion of milestones. } \\
\text { Provide input to the project control organization scheduler for update and } \\
\text { status of the schedule. }\end{array}$ \\
\hline 11. & $\begin{array}{l}\text { Program Administration } \\
\text { Program/Project Control } \\
\text { Cost Account Manager }\end{array}$ & $\begin{array}{l}\text { Maintain the current status of schedules by reflecting progress reported } \\
\text { by the cost account manager. } \\
\text { Report schedule trends and resulting forecast dates. } \\
\text { Compare schedule variances reported in the cost performance report each } \\
\text { month against the schedule to ensure they are reflecting the same } \\
\text { information. }\end{array}$ \\
\hline 12. & $\begin{array}{l}\text { Activity Manager } \\
\text { Cost Account Manager }\end{array}$ & $\begin{array}{l}\text { Prepare change requests for changes to schedule baselines in accordance } \\
\text { with change control procedures. }\end{array}$ \\
\hline 13. & $\begin{array}{l}\text { Program Administration } \\
\text { Program/Project Control }\end{array}$ & $\begin{array}{l}\text { Incorporate approved changes into the milestone control } \log \text { and the } \\
\text { schedule hierarchy ensuring that all schedules reflect the same information. }\end{array}$ \\
\hline
\end{tabular}


HNF-SD-WM-PMP-022, Rev. 0

\section{H.5 REFERENCES}

DOE O 430.1, 1995, Life Cycle Asset Management, U.S. Department of Energy, Washington, D.C.

HNF-PRO-518, Management Systems, Fluor Daniel Hanford, Richland, Washington. 
HNF-SD-WM-PMP-022, Rev. 0

This page intentionally left blank. 
HNF-SD-WM-PMP-022, Rev. 0

APPENDIX I

\section{CHANGE CONTROL AND BASELINE MANAGEMENT}


HNF-SD-WM-PMP-022, Rev. 0

This page intentionally left blank. 


\section{I.0 INTRODUCTION}

Once established, the HTI baseline will be modified via a change control process. The change control process will accommodate both major and minor modifications to the baseline and each change will be approved by change board actions.

\section{I.1 SCOPE}

This change control process will be applied to all elements of the HTI baseline.

\section{I.2 CHANGE CONTROL BOARD}

The HTI change control board will be chaired by the HTI Project manager. Board members will be appointed by the project manager. The board will meet once each month, but can be convened at any time.

\section{I.3 LEVELS OF CHANGE CONTROL}

All change requests will be classified as follows:

Class I - Class I changes require disposition by the RL TWRS director and the PHMC Management Systems Director. Class I changes are changes that affect the technical or the performance measurement baseline.

Class II - Class II changes require disposition by the TWRS project and/or subproject manager, and the management systems director. Class II changes are changes of scope, schedule, and/or budget at the cost account level of a project.

Class III - Class III changes require disposition by the cost account manager. Class III changes occur below the cost account level and do not affect baseline cost, scope, or schedule.

\section{I.4 CHANGE CONTROL DOCUMENTATION}

Changes are documented on a change control form that identifies impacts and justifications for the change. The change control form documents the before and after aspects of the proposed change. 


\section{I.5 CHANGE CONTROL IMPLEMENTATION}

As each change package is approved, authorization is given to each scheduler and budget analyst to implement the prescribed changes as described and modified by the board and its associated review process.

\section{I.6 REFERENCE}

FDH-PRO-518, Management Systems, Fluor Daniel Hanford, Richland, Washington. 
HNF-SD-WM-PMP-022, Rev. 0

\section{APPENDIX J}

\section{PERFORMANCE MANAGEMENT AND EARNED VALUE}


HNF-SD-WM-PMP-022, Rev. 0

This page intentionally left blank. 


\section{J.0 INTRODUCTION}

This appendix describes the responsibilities, flow, and sequence of activities relating to measurement of performance and reporting of variances for the Management Control System (MCS). This scope includes the procedure for reporting and analyzing significant cost and schedule variances, and the means to document and analyze performance at the lowest level of the WBS.

\section{J.1 VARIANCE THRESHOLDS}

To provide for management by exception, percentage and dollar thresholds have been developed for each level of performance measurement, from the cost-account level to the program and/or project reporting level. Only variances that exceed the thresholds require a formal variance analysis report. Although the program and/or project manager or DOE can impose more stringent thresholds if desired, unless otherwise specified the minimum thresholds assigned for all variances are as follow:

- Budgeted cost of work scheduled (BCWS) under $\$ 500,0000= \pm 10 \%$ and $\pm \$ 10,000$

- $\quad$ BCWS over $\$ 500,000= \pm \$ 50,000$.

Positive variances will be evaluated as well because they may indicate underruns that would require preparation of an estimate at completion (EAC). The EACs of the financial data system (FDS) provide the WBS activity managers and the program and/or project managers with indications of excess or insufficient funding.

\section{J.2 RESPONSIBILITIES}

Responsibilities of individuals and organizations for the measuring and reporting of cost and schedule performance are as follow.

\section{J.2.1 Cost Account Manager}

The cost account manager (CAM) is responsible for monthly reporting of the progress of work defined by cost accounts. The CAM is also responsible for analyzing the problem, cause, impact, and corrective action for each variance that exceeds the specified variance thresholds. Other responsibilities include documenting the analysis on the Variance Analysis Report (VAR). 


\section{J.2.2 Program Administration and/or Project Control Organizations}

Program administration and/or project control organizations are the focal points for the collection and reporting of performance data. Activities which comprise the performance of this function are the following:

- Collecting, reviewing, and entering the cost account or task package performance data into the performance measurement database

- Updating project schedules to reflect current status

- Determining which cost account variances exceed established threshold limits

- Transmitting a VAR (with header filled in) to the CAM for out-of-tolerance variances

- Reviewing the completed VAR prepared by the CAM to ensure that all required analyses have been performed and properly documented before the VAR is forwarded to the activity manager

- Summarizing VARs at activity and end-function levels for monthly reporting.

\section{J.2.3 Function Manager}

The function manager may be requested to provide a statement to the CAM when an overspent or underspent condition exists for a task package, which is the responsibility of that organization.

\section{J.2.4 Activity Manager}

The activity manager is responsible for providing the end-function manager and/or program manager with a complete analysis of out-of-tolerance variances identified by the performance reports. The activity manager reviews the completed VARs from the CAM to ensure that they adequately explain the causes for the variance, the impact on the cost account and the overall project, and the corrective actions recommended. If the VAR is not complete or adequate, the activity manager is responsible for reviewing it with the CAM and making needed changes.

\section{J.2.5 End-Function Manager}

The end-function manager is responsible for reviewing performance analysis information in preparing end-function sections of the monthly performance report and evaluating the need for revised funding guidance. 


\section{J.3 REQUIREMENTS}

\section{J.3.1 Data Analysis}

Data analysis allows analysts and responsible management to identify problems, determine reasons for deviations from plans, take corrective actions, and to report results. Several methods of variance analysis are available for use by the CAMs and the program administration representatives. Good analysis provides consistent information easily understood by all levels of personnel and can be completed quickly when VARs are required.

Through the use of discrete WBS codes, computerized performance reports showing cost and schedule variance information are available to PHMC managers. Information from this database can also be summarized by organization code. These features of the database allow managers to access variance information at the level of detail required for effective control.

\section{J.3.2 Schedule Variance}

Schedule variance is reported at the cost-account level of the WBS for purposes of analysis. Schedule variance equals the BCWP minus BCWS. Schedule variance may be calculated for current month data as well as cumulative-to-date data. Schedule variance indicates whether more or less work was performed than was scheduled. A positive schedule variance indicates planned work is ahead of schedule; a negative variance indicates the planned work is behind schedule. Schedule variance cannot result from level-of-effort (LOE) activities, because the BCWP is, by definition, equal to the BCWS and automatically statused by FDS.

\section{J.3.3 Cost Variance}

Cost variance is reported at the cost-account level for variance reporting. Cost variance equals the $\mathrm{BCWP}$ minus actual cost of work performed (ACWP). Cost variance indicates whether the work actually performed cost more or less than it was planned to cost. Cost variance may be calculated for current period data as well as cumulative-to-date data. A positive cost variance indicates less was spent than planned for the amount of work completed. A negative cost variance indicates more was spent than planned for the work completed.

\section{J.3.4 Estimate at Completion}

The EAC is calculated on the VAR by adding the actual costs-to-date (i.e., ACWP) to the estimate to complete (ETC). The EAC subtracted from the budget at completion (BAC) gives an at-completion-variance (ACV) that forecasts the current expected underrun or 
overrun for a defined scope of work. A positive ACV forecasts an underrun; a negative forecasts an overrun.

\section{J.3.5 Data Analysis Summary}

The cause of a cost or schedule variance is determined by analyzing variance information in performance reports. This determination process includes analysis of cost elements and performing organizations at a level of detail of the WBS required to determine the major cause(s). Impacts are determined by schedule updates and analyses, and forecasting of funding requirements. Corrective action is developed, initiated, and carried out by the CAM to alleviate or diminish any impact to the scheduled completion of work. Corrective actions are monitored to ensure successful resolution of problems.

\section{J.3.6 Performance Reports}

Performance reports are generated from the performance module of FDS that provides the performance data from which variance analysis and reporting is based. These reports include current month and cumulative BCWS, BCWP, ACWP, and schedule and cost variance.

The FDS has a menu which lists the available performance reports. Performance reports are indicated by the letter $P$.

\section{J.4 PROCEDURE}

The procedure is presented in two parts. Part 1 is a flow chart showing steps in the procedure. Part 2 describes the actions and responsibilities for implementing the procedure. 
Part 1 Procedure Flow Chart (sheet 1 of 2)

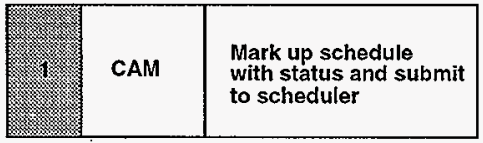

\begin{tabular}{|l|l|}
\hline CON & $\begin{array}{l}\text { Performance reports } \\
\text { available }\end{array}$ \\
\hline
\end{tabular}

\begin{tabular}{|c|c|c|}
\hline 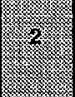 & SC & $\begin{array}{l}\text { Status schedule to } \\
\text { generate BCWP. } \\
\text { Submit to BA }\end{array}$ \\
\hline
\end{tabular}

\begin{tabular}{|l|l|}
\hline CAM/BA & $\begin{array}{l}\text { Review reports and } \\
\text { prepare a VAR form for } \\
\text { each CAP variance } \\
\text { exceeding thresholds }\end{array}$ \\
\hline
\end{tabular}

\begin{tabular}{|l|l|}
\hline Ba & $\begin{array}{l}\text { Input BCWP values } \\
\text { into the performance } \\
\text { data base }\end{array}$ \\
\hline
\end{tabular}

\begin{tabular}{|l|l|}
\hline CAM/BA & $\begin{array}{l}\text { Track VAR forms } \\
\text { prepared and } \\
\text { distributed }\end{array}$ \\
\hline
\end{tabular}
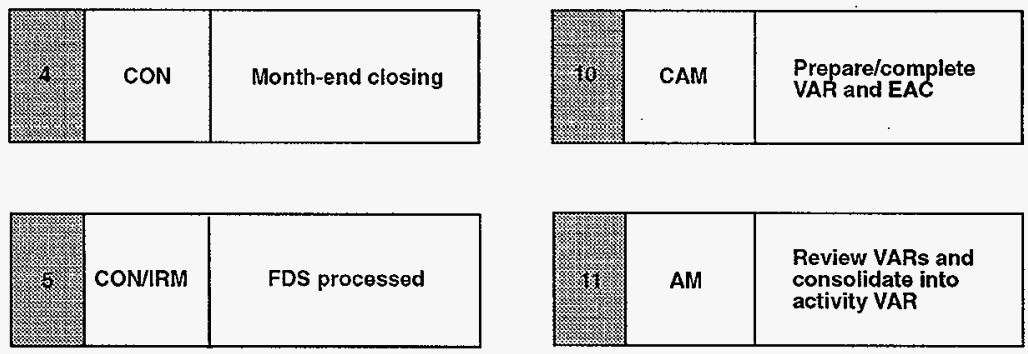

\begin{tabular}{|l|l|}
\hline AM & $\begin{array}{l}\text { Review VARs and } \\
\text { consolidate into } \\
\text { activity VAR }\end{array}$ \\
\hline
\end{tabular}

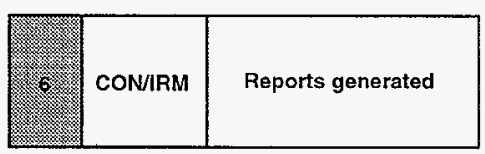

\begin{tabular}{|l|l|}
\hline AM & $\begin{array}{l}\text { Submit activity level } \\
\text { VAR and EAC to } \\
\text { end-function manager }\end{array}$ \\
\hline
\end{tabular}

H97070061.3a 
Part 1 Procedure Flow Chart (sheet 2 of 2)

\begin{tabular}{|l|l|}
\hline PAR & $\begin{array}{l}\text { Prepare end-function } \\
\text { VAR and EAC for use } \\
\text { in monthly reports } \\
\text { and reviews }\end{array}$ \\
\hline
\end{tabular}

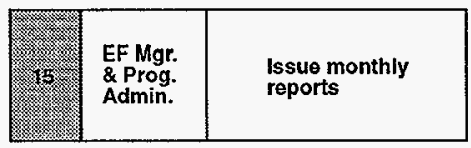

\begin{tabular}{|l|l|}
\hline & \\
EF Mgr. & $\begin{array}{l}\text { Review analysis. } \\
\text { Enter EAC into FDS } \\
\text { as necessary }\end{array}$ \\
\hline
\end{tabular}

\section{Legend:}

$\begin{array}{ll}\text { AM } & \text { activity manager } \\ \text { BA } & \text { budget analyst } \\ \text { BCWP } & \text { budgeted cost of work performed } \\ \text { CAM } & \text { Cost account manager } \\ \text { CAP } & \text { cost account plan } \\ \text { CON } & \text { controller organization } \\ \text { EAC } & \text { estimate at completing } \\ \text { EF } & \text { end function } \\ \text { IRM } & \text { information resource management } \\ \text { PAR } & \text { program administration representative } \\ \text { VAR } & \text { variance analysis report }\end{array}$

H97070061.3b 


\section{J.4.1 Responsibilities and Actions}

The following action descriptions correspond directly with the blocks in Part 1 and provide specific instructions for individuals implementing this procedures. Because timing is of vital importance in this cycle, due days are included.

\begin{tabular}{|c|c|c|c|}
\hline \multicolumn{2}{|r|}{ Responsibility } & Action & Day Due \\
\hline 1. & Cost Account Manager & $\begin{array}{l}\text { Mark up schedule with actual progress on each activity } \\
\text { bar. submit to scheduler for input. }\end{array}$ & $\begin{array}{l}\text { Monday prior to } \\
\text { fiscal month end }\end{array}$ \\
\hline 2. & Scheduler & $\begin{array}{l}\text { Input progress into scheduling system to generate BCWP } \\
\text { figures. Submit to Budget Analyst. }\end{array}$ & $\begin{array}{l}\text { Thursday prior to } \\
\text { fiscal month end }\end{array}$ \\
\hline 3. & Budget analyst & $\begin{array}{l}\text { Input BCWP values into the performance database. } \\
\text { Ensure an entry is made for each task package that was } \\
\text { open or was scheduled to be open except for level-of-effort } \\
\text { task packages. }\end{array}$ & $\begin{array}{l}\text { Friday prior to } \\
\text { fiscal month end }\end{array}$ \\
\hline 4. & Controller & Month-end closing. & $\begin{array}{l}\text { Last Sunday of } \\
\text { month }\end{array}$ \\
\hline 5. & Controller and IRM & FDS processed. & Tuesday \\
\hline 6. & Controller and IRM & Reports generated. & Wednesday \\
\hline 7. & Controller & Performance reports available on the HLAN and/or FDS. & Thursday \\
\hline 8. & $\begin{array}{l}\text { Cost Account Manager } \\
\text { and Budget Analyst }\end{array}$ & $\begin{array}{l}\text { Review reports and prepare a VAR for each cost account } \\
\text { plan variance exceeding thresholds, according to pre- } \\
\text { established guidelines. Generally the thresholds are } \pm 10 \% \\
\text { and } \pm \$ 10 \mathrm{~K} \text { for cumulative BCWS under } \$ 500 \mathrm{~K} \text { and } \\
\pm \$ 50 \mathrm{~K} \text { for cumulative budgets over } \$ 500 \mathrm{~K} \text {. A monthly } \\
\text { threshold and monthly VARs are required for major } \\
\text { system acquisitions and major projects. The program or } \\
\text { project manager may modify the thresholds, as required. }\end{array}$ & Monday \\
\hline 9. & $\begin{array}{l}\text { Cost Account Manager } \\
\text { and Budget Analyst }\end{array}$ & $\begin{array}{l}\text { Track VAR forms prepared and distributed to CAMs. } \\
\text { Forward a copy of the status, including any BCWS } \\
\text { adjustments made, via a change request. Forward a copy } \\
\text { of the status to the appropriate program administration } \\
\text { manager. }\end{array}$ & Monday \\
\hline & Cost Account Manager & $\begin{array}{l}\text { Prepare VAR and EAC per thresholds, as requested by the } \\
\text { activity manager or as needed to accurately present the } \\
\text { cost account plan status. } \\
\text { Obtain information from other organizations as necessary } \\
\text { to support the analysis. When a cost account plan contains } \\
\text { task packages that are the responsibility of outside } \\
\text { organizations, the CAM coordinates the analysis of } \\
\text { variances with the responsible task package manager. } \\
\text { (Note steps A through F.) } \\
\text { NOTE: Steps (A) through (E) below refer to } \\
\text { completion of the VAR form. }\end{array}$ & Wednesday \\
\hline
\end{tabular}




\begin{tabular}{|c|c|c|}
\hline Responsibility & \multicolumn{2}{|l|}{ Action } \\
\hline Step A. & \multicolumn{2}{|c|}{$\begin{array}{l}\text { Describe major problem(s) and cause(s). Although several contributing factors } \\
\text { may exist, it is likely that no more than one or two have caused the majority of } \\
\text { the variance (e.g., something was not accomplished; material or equipment was } \\
\text { not delivered; tests results were not available; etc.). When the specific problems } \\
\text { are identified, describe why the problem occurred (e.g., a job was not } \\
\text { accomplished due to lack of manpower; material did not arrive on time due to a } \\
\text { design change; test results were not available because another organization was } \\
\text { late; etc.). Document this information in the VAR so the function manager and } \\
\text { the activity manager understand the problem and its cause. }\end{array}$} \\
\hline Step B. & \multicolumn{2}{|c|}{$\begin{array}{l}\text { Describe the potential impact of the problem (if any). Identify the ultimate } \\
\text { impact on the cost account and program and project. For example, allowing the } \\
\text { problem to continue may result in an unacceptable schedule or cost variance at } \\
\text { completion of the cost account. This, in turn, may impact another cost account } \\
\text { or a major milestone, which may, in turn, result in serious effects on the overall } \\
\text { project or program. } \\
\text { Estimate the magnitude of the variance at completion of the problem is not } \\
\text { corrected. }\end{array}$} \\
\hline Step C. & \multicolumn{2}{|c|}{$\begin{array}{l}\text { Describe the corrective action plan that has been implemented to minimize the } \\
\text { unfavorable impact of actions for coordination with the function manager and the } \\
\text { activity manager. If participants not controlled by the CAM are involved, the } \\
\text { AM is required to review and approve the plan before it is implemented. } \\
\text { Corrective actions are to be aimed at the causes of the problem to ensure long- } \\
\text { term effectiveness. Also include updates of any previously reported corrective } \\
\text { action plan on the VAR to ensure that all related work that may be affected is } \\
\text { made visible. }\end{array}$} \\
\hline Step D. & \multicolumn{2}{|c|}{$\begin{array}{l}\text { Will variance at the end of the fiscal period be significant if the planned } \\
\text { corrective actions will not eliminate the current variance (or most of it) go to } \\
\text { step (E). If you expect the variance to be eliminated by the corrective actions, } \\
\text { go to step (F). }\end{array}$} \\
\hline Step E. & \multicolumn{2}{|c|}{$\begin{array}{l}\text { Review the cost account estimate at completion (EAC). If the estimate to } \\
\text { complete the work is less than, or equal to, the remaining budget, provide an } \\
\text { updated EAC per the EAC procedure. }\end{array}$} \\
\hline Step F. & \multicolumn{2}{|c|}{$\begin{array}{l}\text { Secure function manager's approval and forward the original to the activity } \\
\text { manager, with copies to PAR and the budget analyst. }\end{array}$} \\
\hline Responsibility & Action & Day Due \\
\hline 11. Activity Manager & $\begin{array}{l}\text { Review VARs and consolidate into the activity VAR. } \\
\text { NOTE: The activity manager evaluates } \\
\text { acceptability of the VAR. when a problem exists, } \\
\text { the activity manager communicates directly with } \\
\text { the CAM. Return the VAR to the CAM with } \\
\text { guidance for correction/modification to be } \\
\text { incorporated into the subsequent month's VARs. }\end{array}$ & Thursday \\
\hline Activity Manager & $\begin{array}{l}\text { Submit the activity level VAR and EAC to the program } \\
\text { manager. }\end{array}$ & Thursday \\
\hline $\begin{array}{l}\text { 13. Program Administration } \\
\text { Representative }\end{array}$ & $\begin{array}{l}\text { Prepare end-function level VAR and EAC for use in } \\
\text { monthly reports and reviews. }\end{array}$ & Friday/Monday \\
\hline $\begin{array}{l}\text { 14. End Function } \\
\text { Manager/Program } \\
\text { Administration }\end{array}$ & Review analysis. Revise funding guidance if required. & \\
\hline
\end{tabular}


HNF-SD-WM-PMP-022, Rev. 0

Legend:

$\begin{array}{ll}\text { AM } & \text { activity manager } \\ \text { BCWP } & \text { budgeted cost of work performed } \\ \text { CAM } & \text { cost account manager } \\ \text { EAC } & \text { estimate at completion } \\ \text { FDS } & \text { financial data system } \\ \text { HLAN } & \text { Hanford Local Area Network } \\ \text { IRM } & \text { Information Resource Management } \\ \text { PAR } & \text { program administration representative } \\ \text { VAR } & \text { Variance Analysis Report }\end{array}$




\begin{tabular}{|c|c|c|c|c|c|c|c|c|c|c|c|c|c|c|c|c|c|c|c|}
\hline $\mathbf{x}$ & & & & & & & & & & & & & & & & & & 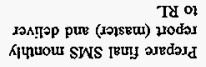 & IL/OI \\
\hline & $\mathrm{x}$ & $x$ & $\mathrm{X}$ & $\mathrm{X}$ & & & & & & & & & & & & & & 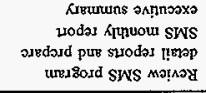 & 6 \\
\hline & & & & $\mathbf{x}$ & & & & & $\mathrm{x}$ & & & & & & & & & 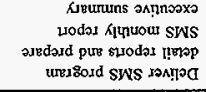 & 8 \\
\hline & & & & $\mathbf{x}$ & $\mathrm{x}$ & $\mathrm{x}$ & $x$ & $\mathrm{x}$ & $\mathrm{x}$ & $\mathrm{x}$ & $x$ & $x$ & $x$ & $\mathrm{x}$ & $\mathrm{x}$ & $\mathrm{x}$ & $\mathrm{x}$ & 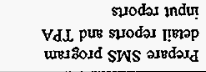 & $2 / 9$ \\
\hline & & & & & & & $\mathrm{x}$ & $\mathrm{x}$ & $\mathrm{x}$ & $\mathrm{x}$ & $\mathrm{x}$ & $x$ & & & & & & 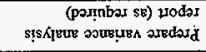 & ' $s$ \\
\hline & & & & & & & & & & & & & $x$ & $\mathrm{x}$ & & & & 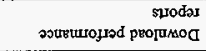 & $\checkmark$ \\
\hline & & & & & & & & & & & & & & & $\mathrm{x}$ & & & 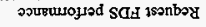 & $\cdot \varepsilon$ \\
\hline & & & & & & & & & & & & & & & & $\mathrm{x}$ & & 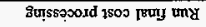 & $\tau$ \\
\hline & & & & & & & & & & & & & & & $\mathrm{x}$ & $\mathrm{x}$ & $x$ & 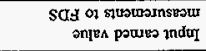 & ' I \\
\hline$I$ & $L I$ & $9 t$ & SI & tit & $\overline{\varepsilon l}$ & $2 !$ & II & OI & 6 & 8 & $L$ & 9 & $\varsigma$ & $t$ & $\varepsilon$ & $z$ & $\mathbf{I}$ & 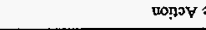 & nposold \\
\hline
\end{tabular}




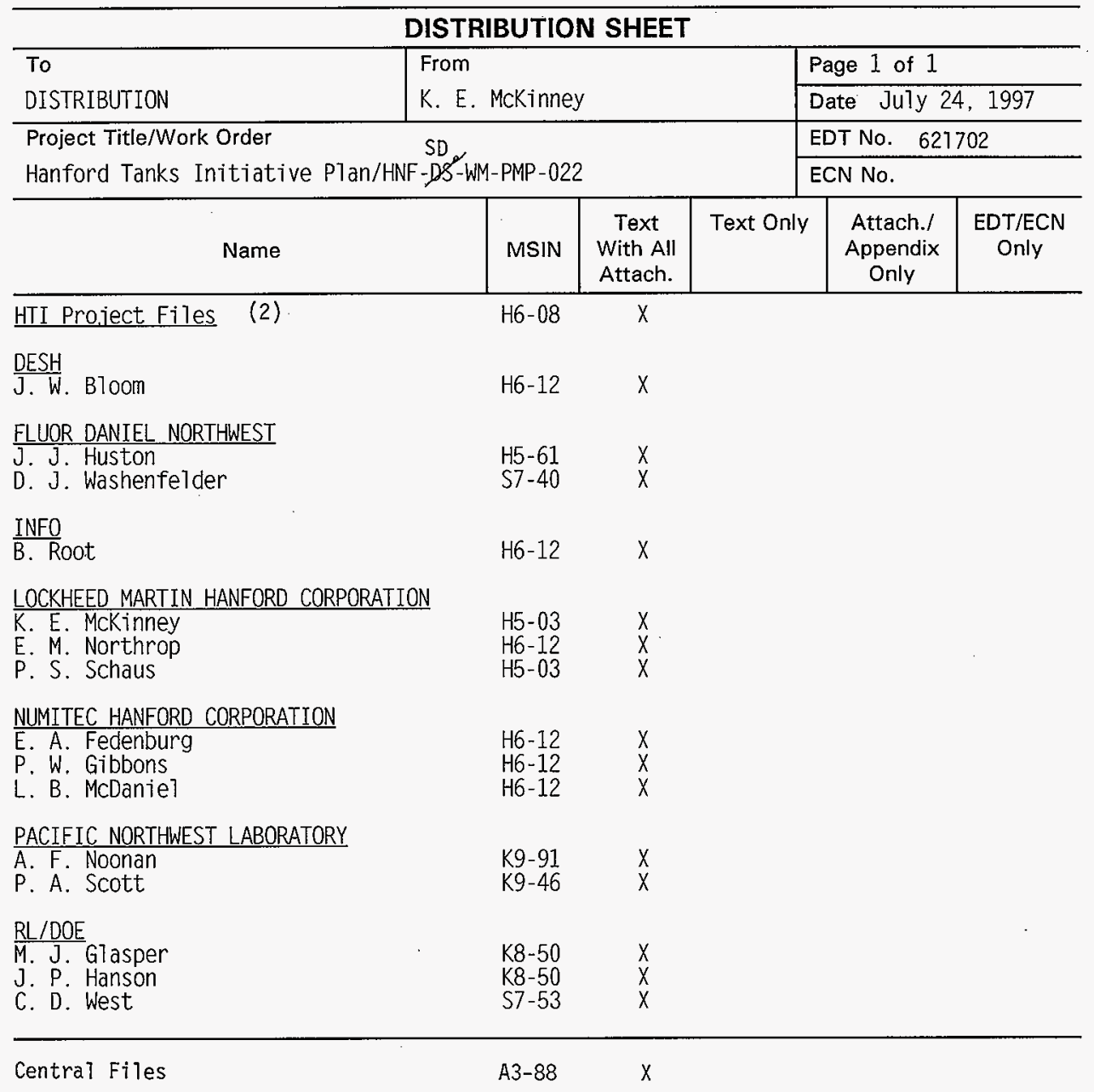

